\title{
PB-288 551
}

Predicted Water-Level and Water-Quality Effects of Artificial Recharge in the Upper Coachella Valley, California, Using a Finite-Element Digital Model

(U.S.) Geological Survey, Menlo Park, CA. Water Resources Div.

Apr 78

QE

75

$.058 w$

no.77-29

1978 


\section{LIBRARY}

SEP 221980 PAAR

Water \& Powerchesources Service

Denver, Colorado 
Predicted Water-Level and ... Water-Quality Effects of Artificial

Recharge in the Upper Coachella Valley,

California, Using a Finite-Element

Digital Model

\section{U.S. GEOLOGICAL SURVEY}

Water-Resources Investigations 77-29

Prepared in cooperation with the

Desert Water Agency and the

Coachella Valley County Water District 


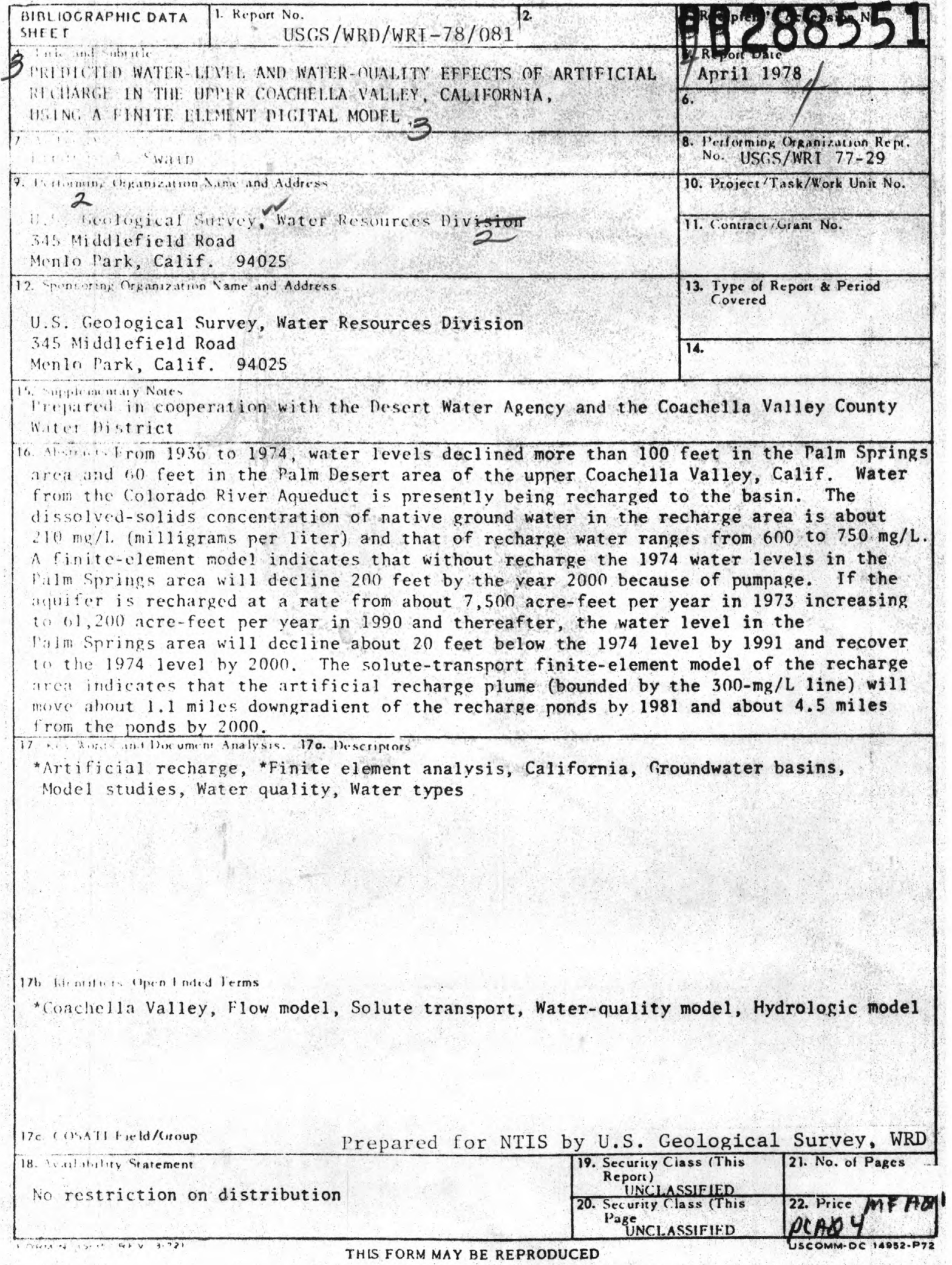


Predicted Water-Level and Water-Quality Effects of Artificial Recharge in the Upper Coachella Valley, California, Using a Finite-Element Digital Model 


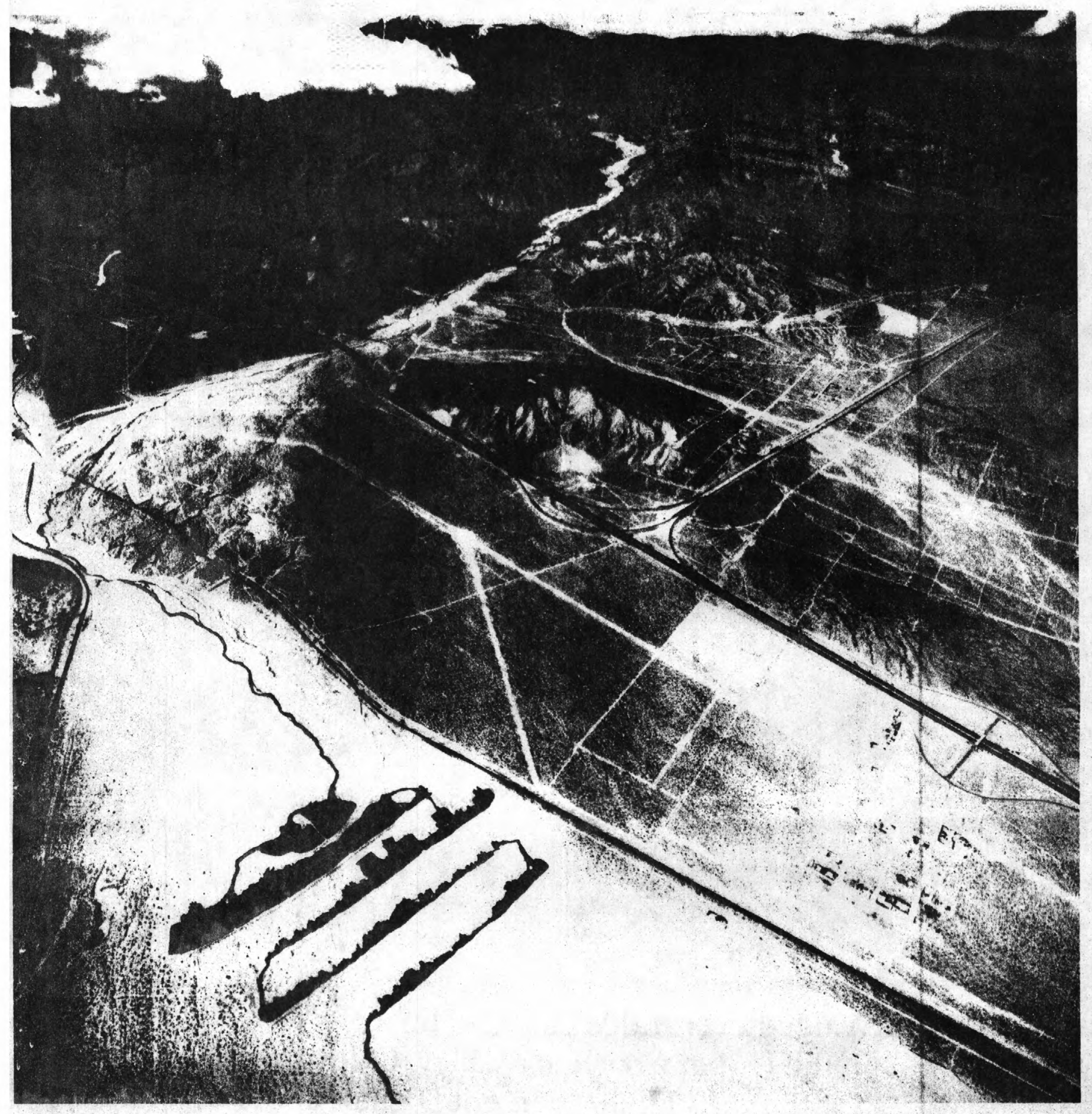

Whitewater River spreading ponds. Photograph courtesy of Desert Water Agency. 


\section{Predicted Water-Level and \\ Water-Quality Effects of Artificial \\ Recharge in the Upper Coachella Valley, \\ California, Using a Finite-Element \\ Digital Model}

By Lindsay A. Swain

U.S. GEOLOGICAL SURVEY

Water-Resources Investigations 77-29

Prepared in cooperation with the

Desert Water Agency and the

Coachella Valley County Water District

$\infty$
1
1
10 
UNITED STATES DEPARTMENT OF THE INTERIOR

CECIL D. ANDRUS, Secretary

GEOLOGICAL SURVEY

H. William Menard, Director

For additional information write to:

District Chief

Water Resources Division

U.S. Geological Survey

345 Middlefield Road

Menlo Park, Calif. 94025 


\section{CONTENTS}

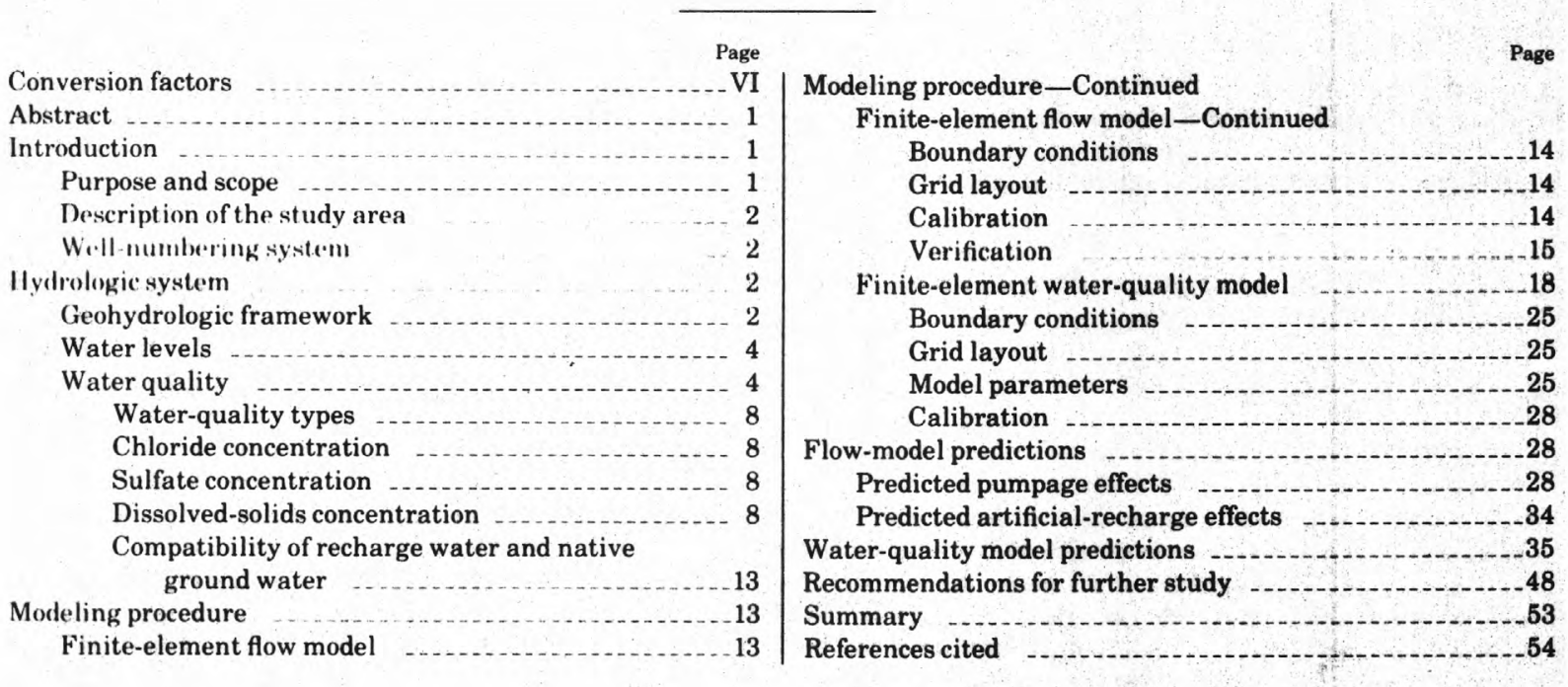

\section{ILLUSTRATIONS}

FrontisPiece. Photograph showing Whitewater River spreading ponds

Figures 1-12. Maps showing:

1. Ground-water subbasins and generalized geology of the upper Coachella Valley, Calif. _.......... 3

2. Water-table contours, 1936

3. Water-table contours, autumn 1973

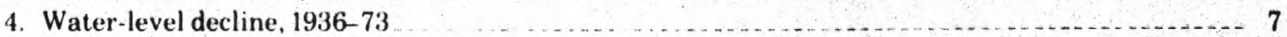

5. Water-quality types _..

6. Chloride concentration

7. Sulfate concentration

8. Dissolved-solids concentration _... 12

9. Grid layout for digital flow model

10. Areal distribution of transmissivity as determined in the steady-state simulation _............. 19

11. Model-generated values for storage coefficients .

12. Comparison of measured and model-generated water-level decline, 1936-68 _................ 23

13. Comparisons of hydrographs generated by digital flow model versus historical measured water levels

14. Map showing grid layout for water-quality model _

15. Graph of past and projected net pumpage for subareas within Whitewater River subbasin, 1936-2000 _._. 30

16-18. Maps showing model-projected water-level decline with projected pumpage-no artificial recharge:

16. For $1974-80 \ldots$

17. For $1974-90 \quad 32$

18. For $1974-2000 \ldots \ldots \ldots \ldots \ldots \ldots$

19-24. Maps showing:

19. Water-level change, 1974-80, with artificial recharge and projected pumpage

20. Difference between projected water levels for 1981 under projected pumpage conditions and artificial recharge combined with projected pumpage condition …..... 37

21. Water-level change. 1974-90, with artificial recharge and projected pumpage

22. Difference between projected water levels for 1991 under projected pumpage conditions and

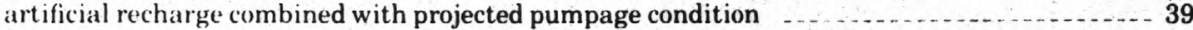

23. Water-level change, $1974-2000$, with artificial recharge and projected pumpage $\ldots \ldots \ldots . . . . . . .40$

24. Difference between projected water levels for 2001 under projected pumpage conditions and artificial recharge combined with projected pumpage condition 
1.wing Page

26. 28. Maps showing model-predicted dissolved-solids concentration, using 650 milligrams per liter artificial recharge water from Colorado River Aqueduct:

26. For 1981

27. For 1991

28. For 2000

29. Graph showing concentration profiles of dissolved solids along section $A-A$ ' of water-quality model for 1981, 1991, and 2000 , using a dissolved-solids concentration of 650 milligrams per liter in the recharge water s showing model-predicted dissolved-solids concentration, using 750 milligrams per liter artificial recharge water from Colorado River Aqueduct:
30. For 1981
31. For 1991
49
50

33. Map showing model-predicted dissolved-solids concentration for the year 2000 , using Colorado River Aqueduct water as artificial recharge from 1974 to 1991 (750 milligrams per liter) and State Water Project water from 1991 to 2000 ( 250 milligrams per liter)

\section{TABLES}

Page

TABLE

1. Steady-state ground-water recharge to Garnet Hill and Whitewater River subbasins

2. Annual net pumpage by subbasins and subareas, 1936 $73 \ldots$

3. Average annual natural ground-water recharge for transient-state simulation

4. Average annual sewage-efluent return from Palm Springs sewage-treatment plant $\quad 21$

5. Porosity values from water-quality model area

6. Average increase in net pumping rate for simulation periods $\ldots \ldots \ldots$

7. Upper Coachella Valley annual entitlements to water from State Water Project through year 2000 ..... 34

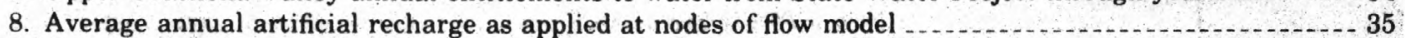

9. Average annual artificial recharge as applied at nodes of water-quality model

\section{CONVERSION FACTORS}

For readers who prefer metric units rather than English units, the conversion factors for the terms used herein are listed below.

$\quad$ Multiply English Unit
acres
acre-ft (acre-feet)
$\mathrm{ft}$ (feet)
$\mathrm{ft}^{2} / \mathrm{d}$ (feet squared per day)
(gal/min)/ft (gallons per
$\quad$ minute per foot)
in (inches)
$\mathrm{mi}$ (miles
$\mathrm{mi}^{2}$ (square miles)

$B y$
$4.047 \times 10^{-1}$
$1.233 \times 10^{-3}$
$3.048 \times 10^{-1}$
$9.29 \times 10^{-2}$
$2.07 \times 10^{-1}$
$2.540 \times 10$
1.609
2.590

By

$1.233 \times 10^{-3}$

$9.048 \times 10^{-1}$

$2.07 \times 10^{-1}$

1.609

2.590
To obtain metric unit $\mathrm{hm}^{2}$ (square hectometers) $\mathrm{hm}^{3}$ (cubic hectometers) m (meters) $\mathrm{m}^{2} / \mathrm{d}$ (meters squared per day) (L/s)/m (liters per second per meter)

mm (millimeters) km (kilometers) $\mathrm{km}^{2}$ (gquare kilometers) 


\title{
Predicted Water-Level and Water-Quality Effects of Artificial Recharge in the Upper Coachella Valley, California, Using a Finite-Element Digital Model
}

\author{
By Lindsay A. Swain
}

\begin{abstract}
ABSIRAC:I .
From 1936 to 1974 , water levels declined more than 100 feet in the Palm Springs area and 60 feet in the Palm Desert area of the upper Coachella Valley, Calif. Water from the Colorado River Aqueduct is presently being recharged in the Whitewater River subbasin to help retard this trend of water-level decline.

Water quality in the basin varies from a sodium sulfate type in the northern three subbasins (Desert Hot Springs, Mission Creek, and Garnet Hill) to a calcium bicarbonate type in the southernmost Whitewater River subbasin. Dissolved-solids concentration ranges from a minimum of 200 milligrams per liter in some parts of the Whitewater River subbasin to a maximum of more than 1,000 milligrams per liter in the Des"1 Ilot Springs subbasin. 'Pho dissolved-solids concentration in the artificial-reshargo water ranges from 600 to 750 milligrams per liter.

Using projected pumpage, the finite-element digital-model simulation indicates that without artificial recharge the 1974 water levels near Palm Springs would decline 40 feet by 1981 , 120 feet by 1991 , and 200 feet by 2000 . It is planned to recharge the aquifer at a rate of about 7,500 acre-feet per year in 1973, increasing to 61,200 acre-feet per year in 1990 and thereafter. If the artificial recharge is applied at this increasing rate, the 1974 water levels near Palm Springs would decline only 20 feet below the 1974 level by 1991 and recover to the 1974 level by 2000 .

The solute-transport (water-quality) finite-element digital-model simulation, using dissolved-solids concentration as the model parameter, indicates that the artificial-recharge plume (bounded by the 300-milligram-per-liter concentration line) would move 1.1 miles downgradient from the recharge ponds by $1981,3.1$ miles by 1991 , and 4.5 miles by 2000 ; the plume boundary would cross Indian Avenue between 1991 and 2000.

Water-quality model simulations using dissolved-solids concentrations of 650 and 750 milligrams per liter for the recharge water resulted in similar plume sizes and in locations that were within 650 feet of each other. A simulation to determine the effects of recharging with water from the State Water Project from 1991 to 2000 showed that the plume would be atrophied at the upstream end and would decrease in concentration at the downstream end.
\end{abstract}

\section{INTRODUCTION}

Ground-water levels declined more than $100 \mathrm{ft}$ from 1936 to 1974 in some areas of the upper Coachella Valley. In an effort to counteract these declining water levels, the Desert Water Agency and the Coachella Valley County Water District contracted with the State of California to purchase water imported from northern California through the California Aqueduct. Because no branch aqueduct presently exists from the California Aqueduct to the Coachella Valley, the water agencies agreed to exchange their annual entitloments to California Aqueduct water with the Metropolitan Water District of Southern California for water from the Colorado River Aqueduct. Since 1973 this imported water has been recharged to the ground-water basin through the Whitewater River channel into the spreading basin where the permeable channel is diked to form ponds (fig. 1). Because this recharge water has a higher dissolved-solids concentration than the native ground water, there is a need to (1) delineate the areal extent of present-day water-quality conditions and (2) develop methods to evaluate and predict changes in water-level and water-quality conditions that are brought about by this recharge.

\section{PURPOSE AND SCOPE}

This study was begun in mid-1973 by the U.S. Geological Survey in cooperation with the Desert Water Agency (DWA) and the Coachella Valley County Water District (CVCWD). The purpose of the study was to (1) analyze the present waterquality conditions of the ground-water basin, (2) 
determine the water-level changes that will result from recharging the aquifer, and (3) determine the water-quality changes that will result from recharging the aquifer.

The study included: (1) Collecting, evaluating, tabulating, and computer processing all available ground-water-quality data for the study area; (2) describing the areal distribution of water quality throughout the ground-water basin; (3) updating the pumpage and other hydrologic data compiled for the analog model of the study area (Tyley, 1974); (4) developing a digital hydraulic (flow) model utilizing the finite-element method; and (5) developing a digital solute-transport (waterquality) model utilizing the finite-element method.

This report presents the results of the 3-year study and the predictions of the possible effects of ground-water recharge on the water resources of the upper Coachella Valley.

\section{DESCRIPTION OF THE STUDY AREA}

The upper Coachella Valley (fig. 1) is a $300-\mathrm{mi}^{2}$ area in Riverside County, Calif., in the northwestern part of the Salton Trough. The study area extends from the east end of San Gorgonio Pass to the town of Indio. It is bordered on the north and east by the San Bernardino and Little San Bernardino Mountains and on the southwest by the San Jacinto and Santa Rosa Mountains. Although there is no topographic divide between upper and lower Coachella Valley, the area of study corresponds with the local concept that the upper valley is separated from the lower valley by the Coachella Canal. This southern boundary is an imaginary line from Point Happy northeast to the Little San Bernardino Mountains. South of the boundary line, water imported from the Colorado River is the major source of irrigation water, and water levels in wells have been rising since 1949. North of the boundary, however, ground water is the major source of irrigation water, and water levels have been declining.

\section{WELLNUMBERING SYSTEM}

Wells are numbered according to their location in the rectangular system for the subdivision of public land. That part of the number preceding the slash (as in $4 \mathrm{~S} / 4 \mathrm{E}-25 \mathrm{H} 1$ ) indicates the township (T. $4 \mathrm{~S}$.), the number following the slash indicates the range (R. 4 E.), the number following the dash indicates the section (sec. 25), and the letter following the section number indicates the 40-acre subdivision of the section according to the lettered diagram below. The final digit is a serial number for wells in each 40-acre subdivision. The area covered by the report lies entirely south and east of the San Bernardino base line and meridian.

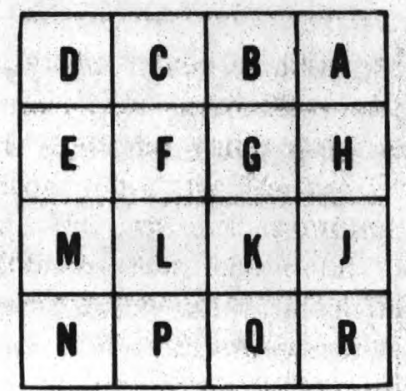

\section{HYDROLOGIC SYSTEM}

\section{GEOHYDROLOGIC FRAMEWORK}

As generalized by Tyley (1974) the lithology of the study area may be divided into three categories: Unconsolidated deposits, semiconsolidated deposits, and consolidated rock (fig. 1).

The consolidated rock forms the basement complex of the valley. This unit is exposed in the mountain ranges which nearly surround the basin. This rock contains little or no water and generally forms a no-flow boundary around and below the semiconsolidated and unconsolidated deposits.

The principal semiconsolidated deposits in the study area underlie the Indio Hills and Garnet Hill. These deposits generally have low permeability, yield only small quantities of water to wells, and are considered poor aquifers.

The unconsolidated deposits constitute the valley fill and are the main water-bearing units in the upper Coachella Valley. In the deeper parts of the basin these deposits are greater than $3,000 \mathrm{ft}$ thick (Biehler, 1964). Based on practical limits of pumping and compression of the aquifer with depth, the effective thickness of the water-table aquifer in the unconsolidated deposits is limited to $1,000 \mathrm{ft}$. Where penetrated by wells, these deposits are moderately to highly permeable and yield large quantities of water to wells. Some wells in the area yield as much as $250(\mathrm{gal} / \mathrm{min}) / \mathrm{ft}$ of drawdown.

Ground-water flow in the unconsolidated deposits is interrupted by the San Andreas fault system 


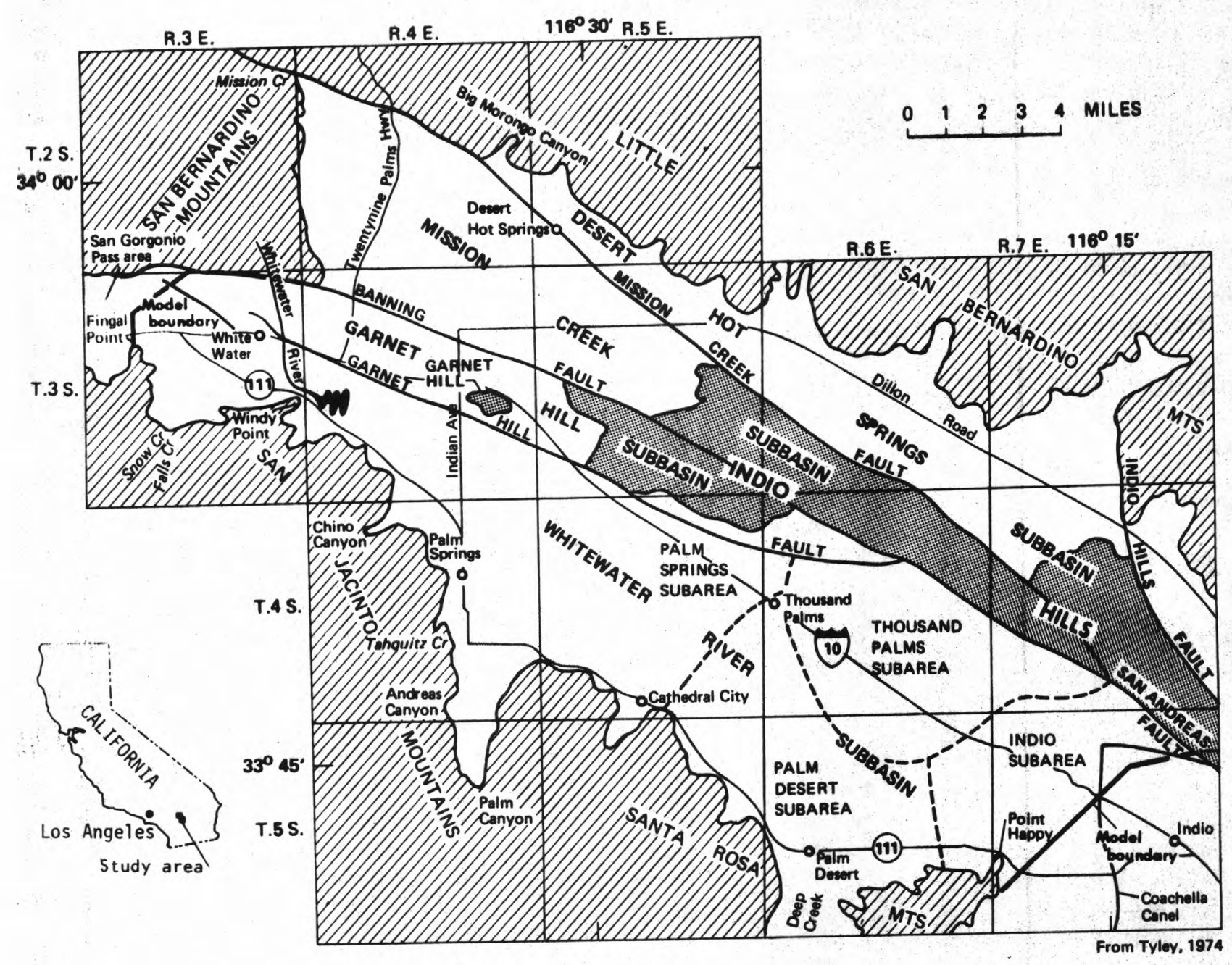

EXPLANATION

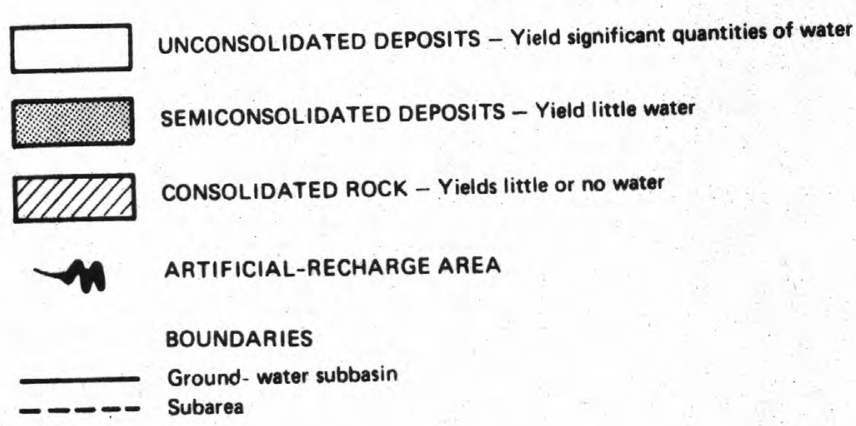

FiguRE 1.-Ground-water subbasins and generalized geology of the upper Coachella Valley, Calif. 
whose principal members in the study area include the Mission Creek, Banning, Garnet Hill, and Indio Hills faults. Because of the low permeability of the unconsolidated deposits along these faults, the basin has been compartmentalized into four almost independent subbasins: Desert Hot Springs, Mission Creek, Garnet Hill, and Whitewater River (fig. 1).

The Desert Hot Springs subbasin, which is mainly composed of coalescing alluvial fans from the Little San Bernardino Mountains, is separated from the Mission Creek subbasin to its southwest by the Mission Creek fault. Because of the low permeability of this fault, water-level differentials of 150 to $250 \mathrm{ft}$ exist across the fault (fig. 2).

The Mission Creek subbasin lies south of the Mission Creek fault and north of the Banning fault. This subbasin consists of unconsolidated and semiconsolidated deposits with the Indio Hills in its southeast extent being of lowest permeability. The Banning fault is an effective ground-water barrier as shown by the 100 - to 300 -ft water-level differentials on opposite sides of this fault (fig. 2).

The Garnet Hill subbasin is separated from the Whitewater River subbasin to its south by the Garnet Hill fault and from the Mission Creek subbasin to its north by the Banning fault. The Garnet Hill fault is an effective ground-water barrier along its northwest extent but less restrictive of ground-water flow at its southeast extent.

The Whitewater River subbasin, the largest of the four subbasins, contains the most significant aquifer. It is bordered on the northwest by the San Gorgonio Pass area (Bloyd, 1971), on the northeast by the Garnet Hill and San Andreas faults, on the southeast by the model boundary where the lower Coachella Valley begins, and on the south by the consolidated rocks of the San Jacinto and Santa Rosa Mountain ranges. The deposits in this subbasin have relatively high permeability (transmissivity as great as 70,000 $\mathrm{ft}^{2} / \mathrm{d}$ ).

The Whitewater River subbasin is further divided into four subareas on the basis of population centers and water use. These subareas are Palm Springs, Thousand Palms, Palm Desert, and Indio (fig. 1).

Because the average rainfall over the valley floor is slightly less than 3 in per year and potential evaporation is $9 \mathrm{ft}$ per year, there is no signif- icant recharge to the ground-water basin from rainfall over the valley floor itself. Average ground-water recharge to the basin as of 1974 , however, was approximately 42,000 acre-ft per year. The recharge occurs as underflow from the San Gorgonio subbasin on the west and from runoff infiltration through the beds of the streams that enter the valley from the surrounding mountains.

Discharge from the basin is principally from pumping, ground-water underflow across the southern boundary of the study area, and some evapotranspiration along the Mission Creek and Banning faults. Net annual pumpage, which ranged from 5,000 acre-ft in 1936 to 53,000 acre-ft in 1973, and consumptive use were estimated and discussed by Tyley (1974). Pumpage rates for each individual year and subbasin are discussed in the modeling section of this report. Annual underflow across the southern boundary was estimated by Tyley $(1974$, p. 24) to be 30,000 acre-ft in 1967 .

\section{WATER LEVELS}

Historical water-level declines and conditions producing those declines have been extensively described by Tyley (1974) and will not be repeated here. The altitude of water levels in the upper Coachella Valley is highest at the northwest end of each subbasin, illustrating that ground-water flow is from the northwest to the southeast in the valley.

Although water levels have been declining throughout most of the basins since 1945 , water levels southeast of the study area have been rising because of increased percolation of imported irrigation water and decreased pumpage in that area.

Comparison of the 1936 water-level map (fig. 2) and the 1973 water-level map (fig. 3 ) shows that water levels declined more than $100 \mathrm{ft}$ in parts of the Palm Springs subarea and more than $70 \mathrm{ft}$ in parts of the Palm Desert subarea during the 37year period (fig. 4). This significant decline, which in recent years has averaged $5 \mathrm{ft}$ annually in the Palm Springs area, has been the cause of great concern to the local water purveyors and prompted the artificial recharging of the ground-water basin.

\section{WATER QUALITY}

Before modeling future changes in water quality caused by artificially recharging the aquifer, the baseline or historic water quality for the aquifer had to be determined. More than 1,000 


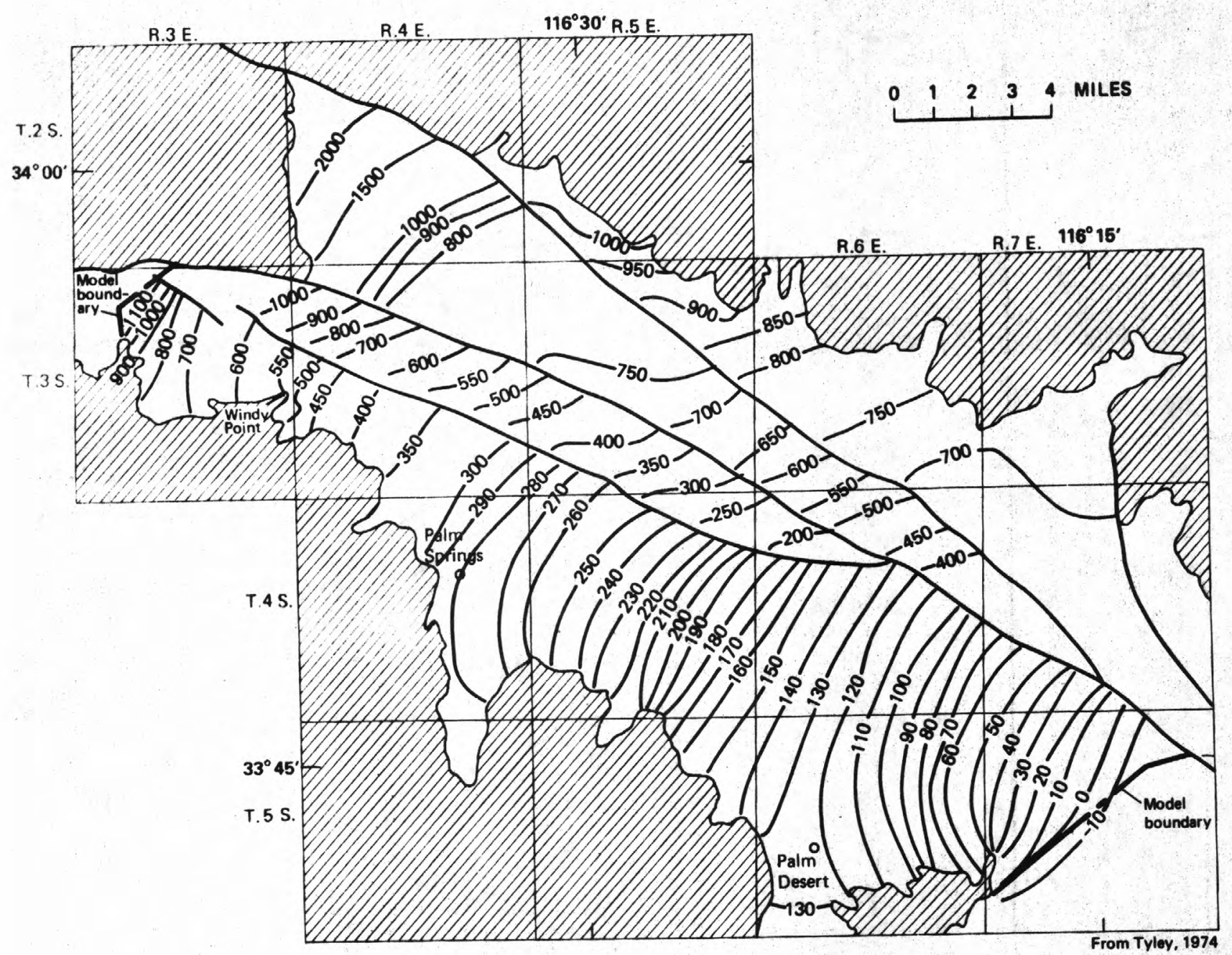

EXPLANATION

UNCONSOLIDATED AND SEMICONSOLIDATED DEPOSITS

CONSOLIOATED ROCK

WATER-TABLE CONTOUR - Shows altitude of water table, in foet. Contour

interval variable. Datum is mean sea level

GROUND-WATER SUBBASIN BOUNDARY

FIGURE 2.-Water-table contours, 1936. 


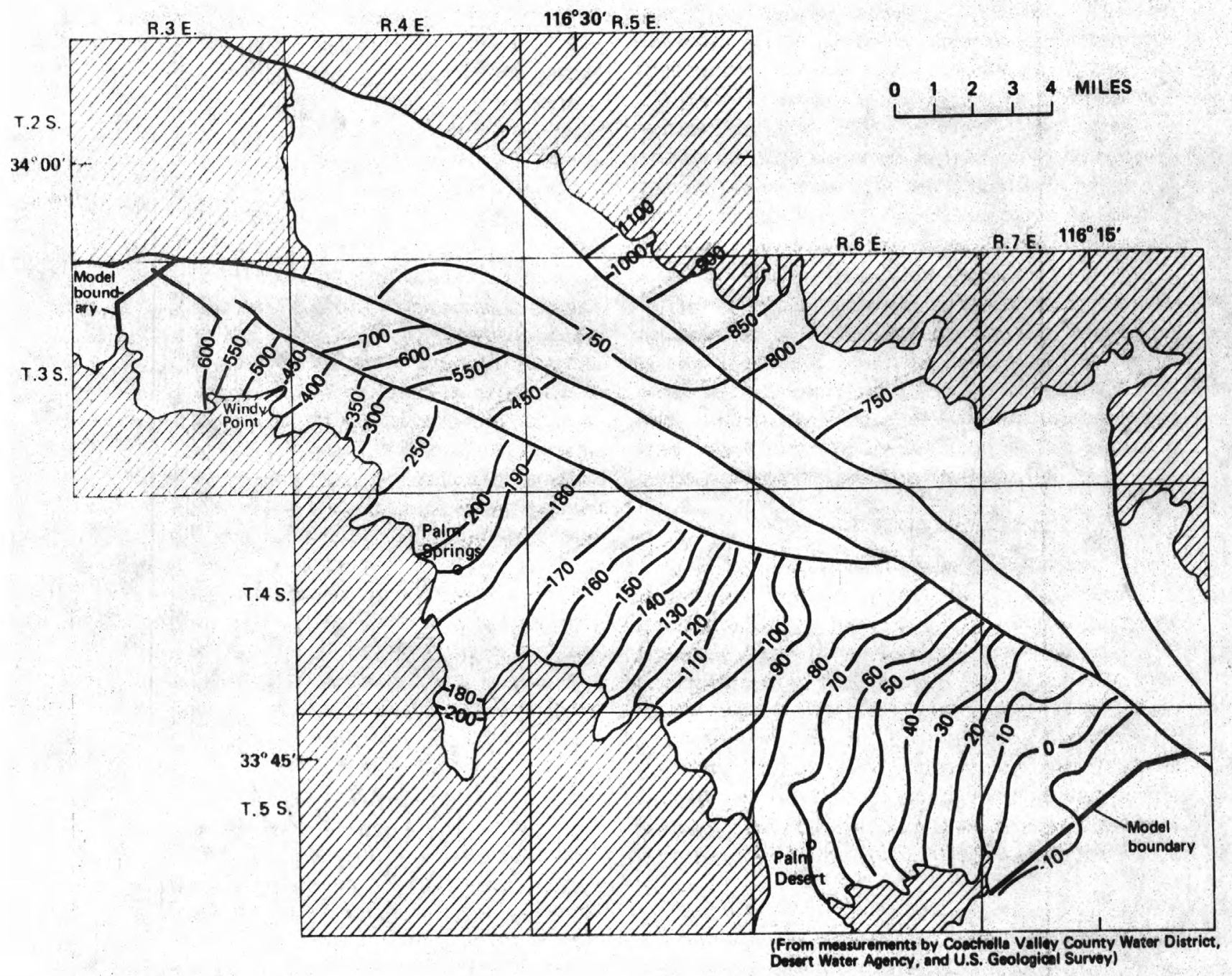

EXPLANATION

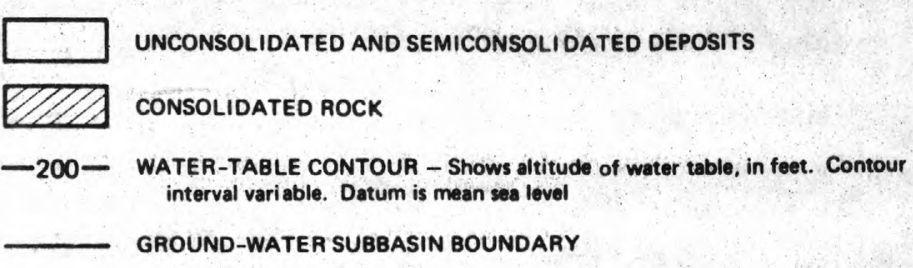

Figure 3.-Water-table contours, autumn 1973. 


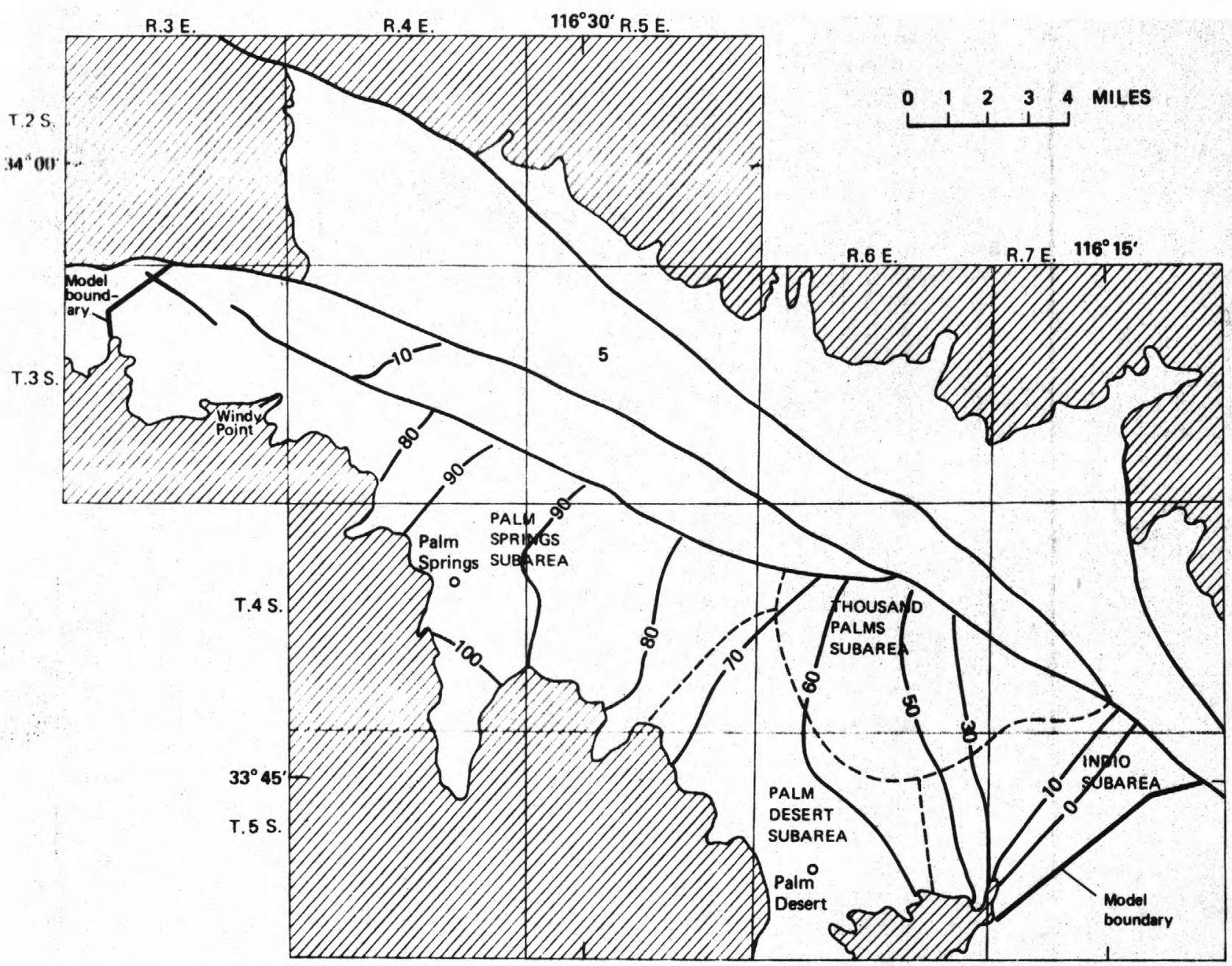

EXPLANATION

UNCONSOLIDATED AND SEMICONSOLIDATED DEPOSITS

DDZ CONSOLIDATED ROCK

- 50- LINE OF EQUAL WATER-LEVEL DECLINE - Interval 10 and 20 feet

BOUNDARIES

Ground-water subbesin

- - - Subarea

Figure 4.-Water-level decline 1936-73. 
chemical analyses were collected from the numerous agencies that analyze or monitor the chemical quality of the ground water in the upper Coachella Valley. After the analyses were evaluated for validity and accuracy, selected ones were used to determine the areal distribution of chosen chemieral constituents and water-quality types.

WIIIR (2IIIIY IYIS

Water-quality types may be distinguished by the predominance of a specific chemical constituent expressed as a percentage of the total anions or cations. For example: (1) A calcium bicarbonate water is one in which calcium amounts to more than 50 percent of the cations and bicarbonate to 50 percent or more of the anions in milliequivalents per liter, and (2) a mixed-type water is one in which either no anion or cation totaled more than 50 percent of the total anions or cations in milliequivalents per liter.

The areal distribution of the water-quality types is shown in figure 5. Each of the three subbasins north of the Garnet Hill fault contains water that is primarily of the sodium sulfate type. Southwest of the fault in the Whitewater River subbasin, however, the water is predominantly a calcium bicarbonate type. The streams that recharge the Whitewater River subbasin are also of the calcium bicarbonate type.

In the areas adjacent to the Garnet Hill fault and near the southeast end of the Banning fault, zones of mixing occur where water of varied water-quality types exists. This situation supports Tyley's (1974) contention that the faults are not as effective barriers to ground-water flow in the southeast as they are in the north. Thus, seepage through the fault on the southeast results in mixing of water-quality types.

Water from the Colorado River Aqueduct is being recharged to the ground-water basin through the Whitewater River channel into the artificial-recharge area (fig. 5). This water fluctuates from a sodium sulfate to a calcium sulfate type at different times.

\section{CHIORIIE CONCENTRATION}

Because chloride is relatively nonreactive after it enters an aquifer, the concentration will be relatively constant as the water moves through the aquifer, unless the water is subjected to evapotranspiration, mixed with other water of a different chloride content, or passes through an area in which the aquifer material is saline. Chloride, therefore, is often a useful chemical constituent in illustrating water-quality changes with time.

Figure 6 shows the variations in chloride concentrations that exist between and within the subbasins. The water of highest chloride concentration, more than $150 \mathrm{mg} / \mathrm{L}$ (milligrams per liter), is in the Desert Hot Springs subhusin. The water of lowest concentration, less than $10 \mathrm{mg} / \mathrm{L}$, is in the Whitewater River subbasin.

The $10-\mathrm{mg} / \mathrm{L}$ chloride concentration in the aquifier beneath the recharge area is in contrast to the $100-\mathrm{mg} / \mathrm{L}$ chloride concentration of the water being recharged. Thus, an increase in chloride concentration in wells around the recharge area may indicate when the recharge water reaches a specific point in the aquifer.

\section{SULFATE CONCENTRATION}

Sulfate is another chemical constituent that is sometimes useful to show major differences in ground-water quality, although sulfate can be reduced by bacterial action or by possible chemical precipitation within the aquifer. This nonconservative nature limits its quantitative application in studies of precision mixing or in modeling.

Figure 7 shows the highest concentrations of sulfate, more than $500 \mathrm{mg} / \mathrm{L}$, in the Desert Hot Springs subbasin and the lowest concentrations, less than $20 \mathrm{mg} / \mathrm{L}$, in the Whitewater River subbasin.

The $30-\mathrm{mg} / \mathrm{L}$ sulfate concentration presently in the aquifer beneath the recharge area is in contrast to the $300-\mathrm{mg} / \mathrm{L}$ sulfate concentration of the water being recharged. Thus, an increase in sulfate concentration in wells around the recharge area may indicate when the recharge water reaches a specific point in the aquifer.

\section{DISSOLVED-SOLIDS CONCENTRATION}

Because it is conservative and uniform areally and with time, the dissolved-solids concentration is useful in showing chemical differences in water. Dissolved-solids concentration shows more distinctive differences for the various subbasins in the area than any of the individual chemical constituents examined in this phase of the study.

Figure 8 shows the 1975 areal distribution of dissolved-solids concentration in the ground water of the upper Coachella Valley. As with the individual chemical constituents, the greatest concentrations, more than $1,000 \mathrm{mg} / \mathrm{L}$, occur in 


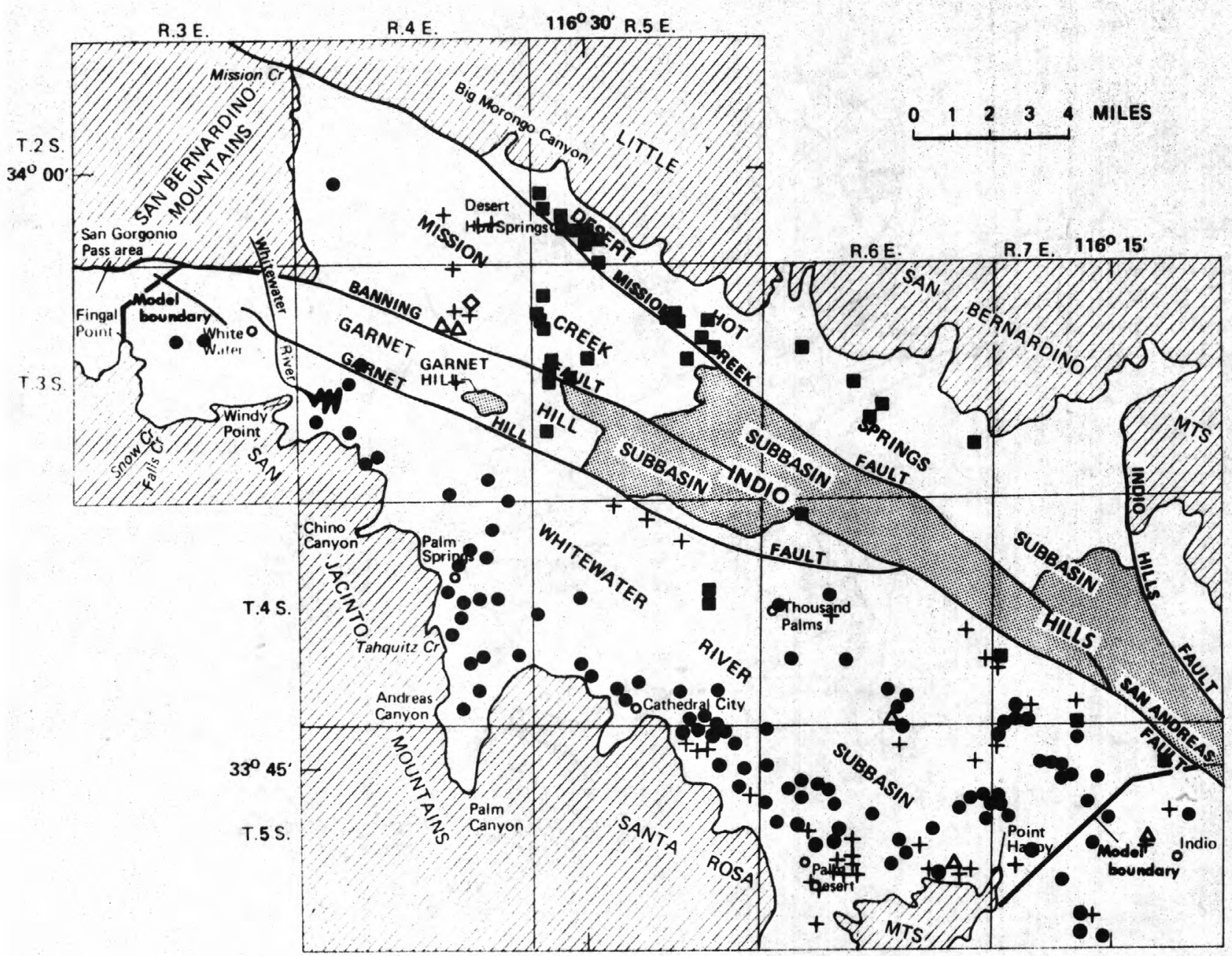

\section{EXPLANATION}

UNCONSOLIDATED DEPOSITS - Yield significant quantities of water

SEMICONSOLIDATED DEPOSITS - Yield little water

CONSOLIDATED ROCK - Yields little or no water

ARTIFICIAL-RECHARGE AREA

WATER-QUALITY TYPES, BASED ON 1968-74 CHEMICAL ANALYSES

Sodium sulfate
Calcium bicarbonate
Calcium sulfate

FIGURE 5.-Water-quality types. 


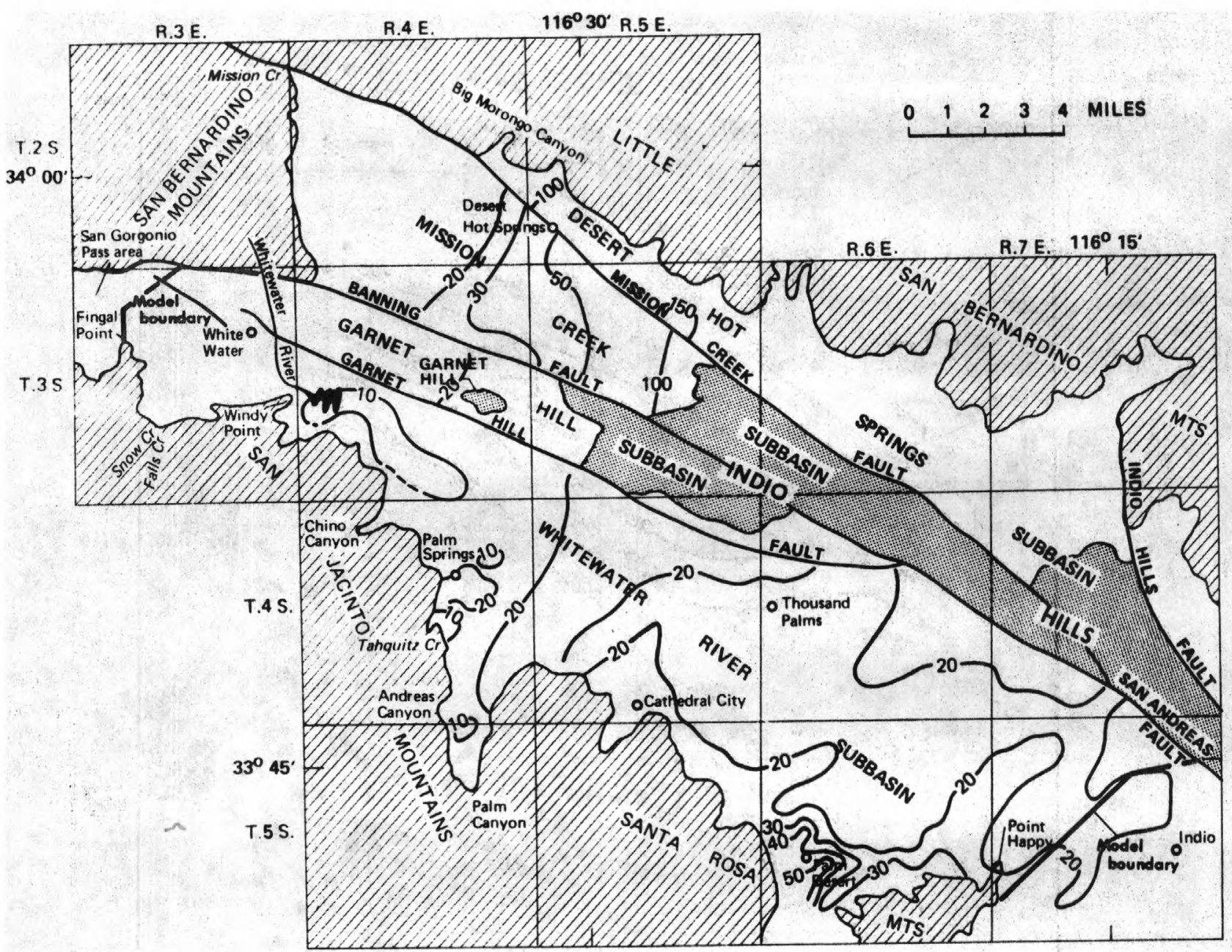

EXPLANATION

UNCONSOLIDATED DEPOSITS - Yield significant quantities of water

SEMICONSOLIDATED DEPOSITS - Yield little water

CONSOLIDATED ROCK - Yields little or no water

II ARTIFICIAL-RECHARGE AREA

- 20 - LINE OF EQUAL CHLORIDE CONCENTRATION, BASED ON 1968-74 CHEMICAL ANALYSES Dashed where approximately located. Interval 10, 20, and 50 milligrams per liter

FIGURE 6.-Chloride concentration. 


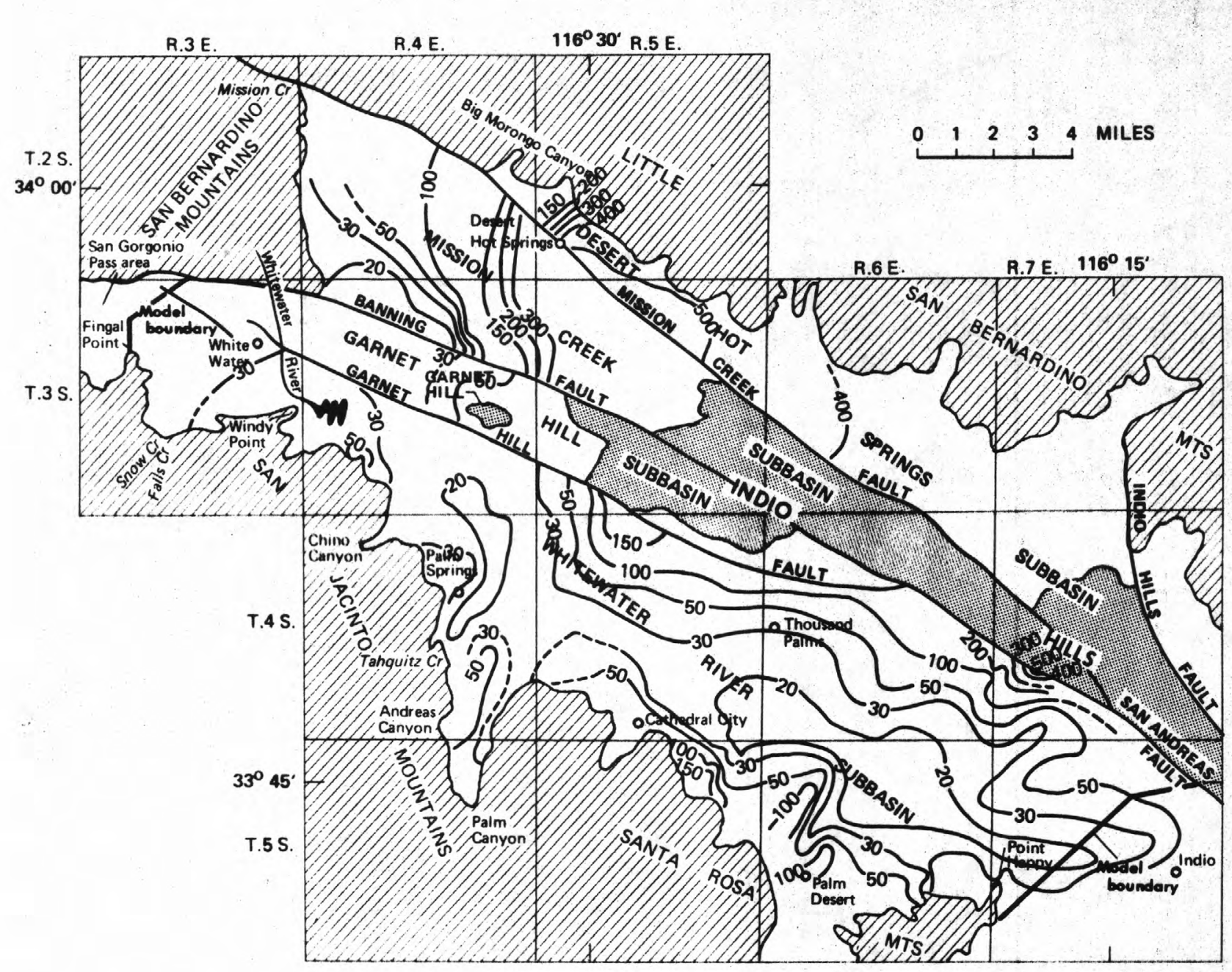

\section{EXPLANATION}

UNCONSOLIDATED DEPOSITS - Yield significant quantities of water

SEMICONSOLIDATED DEPOSITS - Yield little water

CONSOLIDATED ROCK - Yields little or no water

W ARTIFICIAL-RECHARGE AREA

- 30 - LINE OF EQUAL SULFATE CONCENTRATION, BASED ON 1968-74 CHEMICAL ANALYSES Dashed where approximately located. Interval variable, in milligrams per liter

FigURE 7.-Sulfate concentration. 


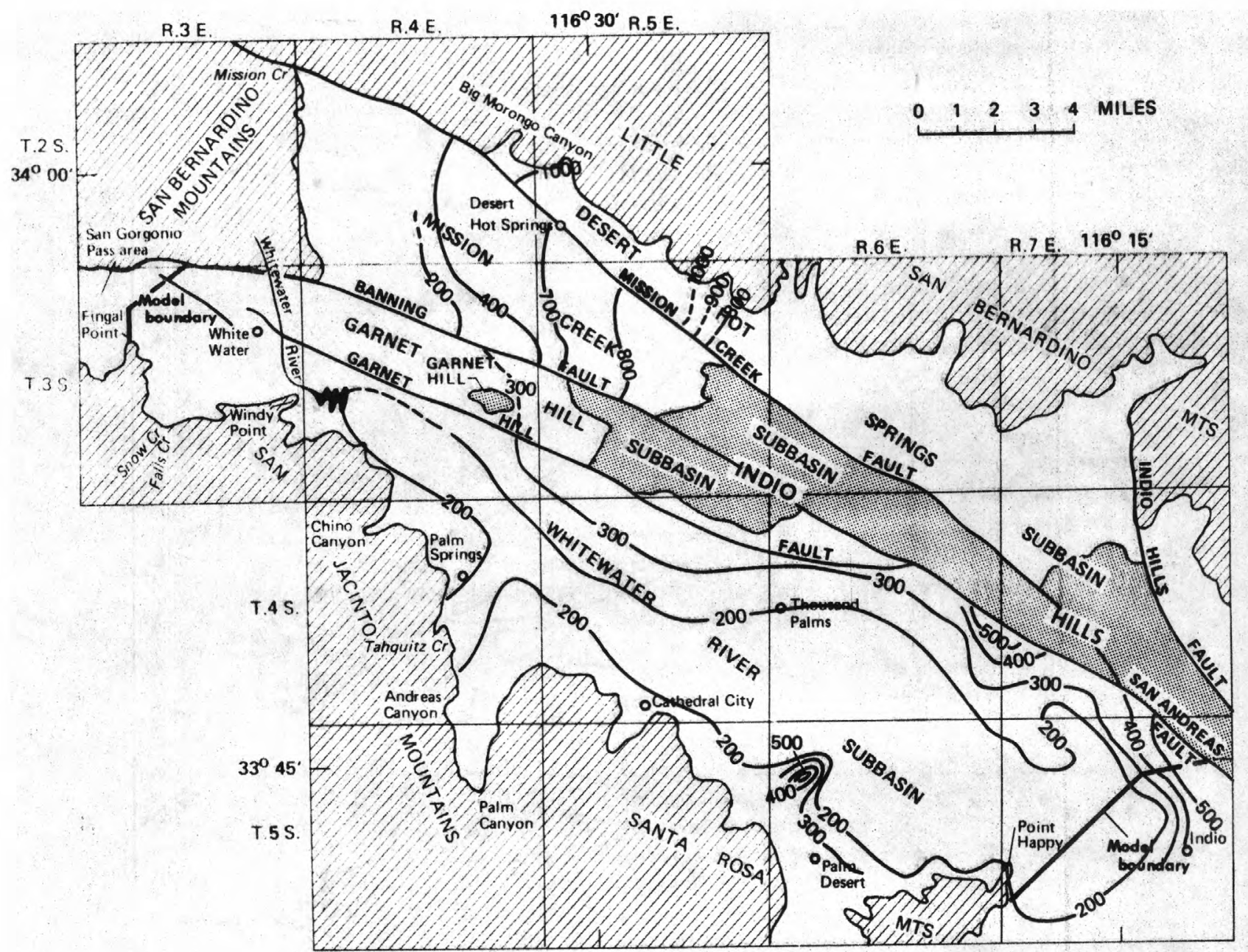

EXPLANATION

UNCONSOLIDATED DEPOSITS - Yield significant quantities of water

SEMICONSOLIDATED DEPOSITS - Yield little water

VII CONSOLIDATED ROCK - Yields little or no water

W ARTIFICIAL-RECHARGE AREA

- 200 - LINE OF EQUAL DISSOLVED-SOLIDS CONCENTRATION, BASED ON 1968-74 CHEMICAL ANALYSES - Dashed where approximately located. Interval 100, 200, and 300 milligrams per liter

Figure 8.-Dissolved-solids concentration. 
the northern part of the Desert Hot Springs subbasin. The water of lowest concentration, less than $200 \mathrm{mg} / \mathrm{L}$, is in some areas of the Whitewater River subbasin.

Dissolved-solids concentration was chosen to be used in the water-quality model to predict the movement of the recharge water. The movement can be predicted because (1) individual wells and subbasins have shown only minor changes in concentration from the earliest samples collected in the 1930 's to the present; (2) the dissolved-solids concentration below the artificial-recharge area is $200 \mathrm{mg} / \mathrm{L}$; and (3) the recharge water has a range in dissolved-solids concentration of 600 to 750 $\mathrm{mg} / \mathrm{l}$. Therefore, an increase in the dissolvedsolids concentration in a well near the recharge area would indicate when the recharge water reached that point in the aquifer.

\section{COMPATIBILITY OF RECHARGE WATER AND NATIVE GROLND WATER}

From mineral-equilibria calculations, Jenne and Truesdell (1973, p. 41) concluded that the mixing of the Colorado River water as recharge with the native ground water of the Whitewater River subbasin "does not indicate the likelihood of any significant quantities of [mineral] precipitation." If no precipitates are formed as a result of the mixing, there should be no decrease in aquifer porosity because of the recharging.

Jenne and Truesdell (1973, p. 43) also concluded that the recharge water infiltrating into the ground-water system would not decrease in dissolved solids unless the water were mixed with the native ground water of a lower dissolvedsolids concentration. Thus, the resulting water quality within the aquifer will be determined by the ratio of the amount of artificial-recharge water to that of native ground water and by the degree of mixing of the two.

\section{MODELING PROCEDURE}

To better understand the aquifer system of the study area, as well as to project water levels and water quality, a digital model can be a useful tool. It cannot be overemphasized that models are tools to be viewed with caution and their results are not to be interpreted as a total duplication of the actual system being simulated. It simply is not possible for a model to include all conditions of the aquifer and water characteristics without ending up with a model the size of the real system itself. Through the use of these models, however, we can approximate the system by average conditions and mathematical representations of how these conditions react. Using the digital computer, the model mathematically calculates the head and water-quality conditions based on: (1) The ability of the aquifer to transmit water (transmissivity) and its capacity to store and release water (storage coefficient); (2) the quality and quantity of water entering the aquifer (recharge); (3) the quality and quantity of water leaving the aquifer (discharge); and (4) the potential of the aquifer to disperse the water of different chemical quality throughout the aquifer (dispersivity).

\section{FINITE-ELEMENT FLOW MODEL}

The flow model chosen for this study utilizes the finite-element numerical method of solution to the following generalized equation of 2-dimensional ground-water flow in an isotropic heterogenous aquifer.

$$
\frac{\partial}{\partial x}\left[T \frac{\partial h}{\partial x}\right]+\frac{\partial}{\partial y}\left[T \frac{\partial h}{\partial y}\right]=S \frac{\partial h}{\partial t}+W
$$

where $h=$ hydraulic head $(L)$

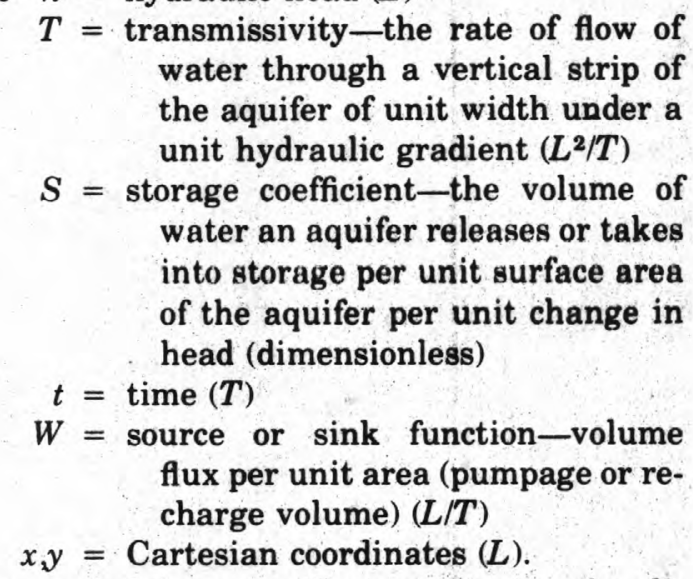

The symbol in parentheses indicates the dimension in which a parameter is measured.

$$
\begin{aligned}
& L=\text { length } \\
& T=\text { time. }
\end{aligned}
$$

The specific computer program used for the flow model was developed by G. F. Pinder (written commun., 1974) and uses isoparametric quadrilateral elements. This program requires a grid system of four-sided elements where the corners of each element are the data points called nodes. As many as two additional nodes may be used on 
each element side to describe curvature of the side.

One advantage of this model over others is that the elements may be irregular shapes of varied sizes. This condition allows for smaller, more numerous elements with more data points in areas of greatest interest or most information and larger elements in areas of less concern or limited data.

A further advantage of this model for this basin is the relative ease of simulating the effects of faults on the ground-water flow system. This can be done by using a line of narrow elements with very low transmissivity. In figure 9 the Garnet Hill fault is represented by the narrow line of elements that are three elements south of the northern boundary of the model.

The flow model for the upper Coachella Valley was developed for only the Garnet Hill and Whitewater River subbasins for the following reasons:

1. The analog model (Tyley, 1974) showed that artificial recharge in the Whitewater River subbasin would have no effect northward across the Banning fault.

2. On the basis of time, cost, and computerstorage requirements, the upper Coachella Valley is too large an area to be simulated using a fine enough grid spacing for the data to be meaningful.

\section{BOUNDARY (ONDITIONS}

The upper Coachella Valley flow model had specified-flux boundaries everywhere except for the southeast end. This southeast boundary has historically been a transition zone or hinge-line between the declining water levels of the upper Coachella Valley and the rising water levels of the lower valley to the southeast. Because water levels at this boundary have been relatively unchanged since 1936, even though they declined more than $60 \mathrm{ft}$ just $4 \mathrm{mi}$ to the west, this boundary was treated as a constant-head boundary in the model (fig. 9). Even though future water-level changes might occur along this southeast boundary as a result of projected pumpage increases, the effect of treating this boundary as one of constant head should be localized and minor. Treatment of this boundary in such a manner will also take into consideration the hydrologic effects of the lower valley in the model and internally com. pute the inflow or outflow rates necessary to maintain the constant head.

Because the Banning and San Andreas faults forming the northeast boundary create an effective flow boundary, only a small quantity of water probably seeps southward through these faults into the model area. Thus, this is a specified-flux boundary with a low flux rate.

Likewise, the total underflow and surfacewater recharge from the San Gorgonio basin along the northwest boundary are accounted for by three non-zero specified-flux boundary nodes, the remaining nodes along this boundary being zero-flux nodes.

The contact of the impermeable consolidated rocks of the San Jacinto and Santa Rosa Mountains along the southwest boundary is predominantly a no-flow boundary. Where surface water recharges the ground-water basin via mountain streams, the flux is specified at a recharge node.

\section{GRID LAYOUT}

The finite-element grid layout as developed for the upper Coachella Valley is shown in figure 9. The grid was designed to have finer spacing in the artificial-recharge area and coarser spacing in the lower end of the valley. It consists of 209 elements with 262 nodes or data points. The smallest element (43) is about 1,750 by $2,250 \mathrm{ft}$, and the largest element (208) is 9,000 by $11,000 \mathrm{ft}$.

\section{C.ALIBRATION}

To be useful as a tool for predicting future water levels, the model should be able to duplicate the present and past water levels from historical data.

The first steps in duplicating these past and present water levels consist of the determination of (1) a steady-state period before any maninduced stresses and (2) the hydrologic characteristics responsible for the water levels of that period. A steady-state condition exists when the system is in a state of dynamic equilibrium and the natural inflow equals the outflow.

Steady-state simulation.-As determined by Tyley (1974), 1936 is the period that best represents a natural equilibrium condition for the aquifer. Antecedent conditions were neither unusually wet nor dry, and sufficient hydrologic 
data were available for that year to permit reasonable simulation.

Table 1 shows the natural-recharge quantities that were used in the steady-state simulation runs. Steady-state water levels are solely dependent on the quantity of recharge and discharge and on the transmissive character of the aquifer. For example, using a set quantity of recharge, a low transmissivity would give a steep water-table gradient, and raising the transmissivity would lower the water-table gradient.

On the basis of additional data and refinements of the data to element-size areas, the average $T$ values originally published by Tyley (1974) were adjusted in this steady-state simulation to obtain $T$ values for each element within the model. Figure 10 shows these $T$ values determined in the steady-state analysis. The water-level map (not shown) for the steady-state period (1936) generated by the model was within $4 \mathrm{ft}$ of the measured 1936 water levels throughout the model area.

Transient-state simulation.-Once the $T$ values had been determined by the steady-state simulation and the initial (1936) water levels assigned to each node, model simulations were made for the period 1936-68 using 2-year time steps to simulate transient or time-dependent conditions. For the transient simulations the net pumpage had to be determined for each year, and average annual natural recharge had to be determined by source. Annual net pumpage and average annual recharge values used in the transient-model simulation are shown in tables 2 and 3, respectively. Because of increased urban development and dewatering of the San Gorgonio Pass subbasin when the tunnel for the Metropolitan Water District of Southern California was drilled, recharge from this area was less in the transient-state simulation than in the steady state. Likewise, changes in diversion practices are reflected in the differences in amount of recharge from mountain streams. Table 4 shows the amount of recharge to the aquifer from sewage infiltration.

Because the recharge and discharge volumes affect water-level changes according to the volume of pore space that can be filled or dewatered, the storage coefficient is the sensitive parameter adjusted in the transient simulation. For example, if, in attempting to duplicate the water levels over the transient-time period, the resultant levels are too high, the storage coefficient can be adjusted in order to lower the water levels in the aquifer. Thus, adjustment within reasonable limits of the storage coefficient can be made in order to duplicate measured water levels.

Figure 11 shows the values for the storage coefficients that were determined from the transient simulation (1936-68) and which gave reasonable 1968 water levels. In the model area the storage coefficient ranges from 0.02 in the Palm Springs subarea to 0.19 in the Palm Desert-Thousand Palms subareas. The lower storage coefficient in the Palm Springs subarea reflects the poorly sorted mixture of large boulders, gravel, sand, and intermittent clay layers that makes up the subarea. Figure 12 shows a comparison of the measured and model-generated water-level decline for the transient-state simulations.

Figure 13 shows a comparison of measured water-level declines in selected wells with declines determined by the model at nodes near the selected well. The period 1936 to 1968 in these hydrographs is the transient simulation period over which the model was calibrated. The similarity in the shape of the curves indicates that the model closely represented the hydrologic response of the ground-water system.

\section{VERIFIC:ATION}

An acceptable fit of the water levels from 1936 to 1968 was generated by adjustments to transmissivity in steady-state simulation and storage coefficients in transient simulation. The model was then run from 1968 to 1974 using annual pumpage determined during this study (table 2). The results of this run verified the model and the chosen parameter values within the acceptable limits of cost and time. The portion of the hydrographs (fig. 13) from 1968 to 1973 shows the good representation of the system in duplicating water levels. The very short time span, however, and the greatly fluctuating unknowns from recharge infiltration, especially as a result of the 1969 flood, made this simulation run difficult.

Having verified that the parameters chosen were reasonable and that the model was capable of duplicating the response of the aquifer, it is now possible to use the model to predict water levels from projected pumpage and (or) projected artificial recharge. 


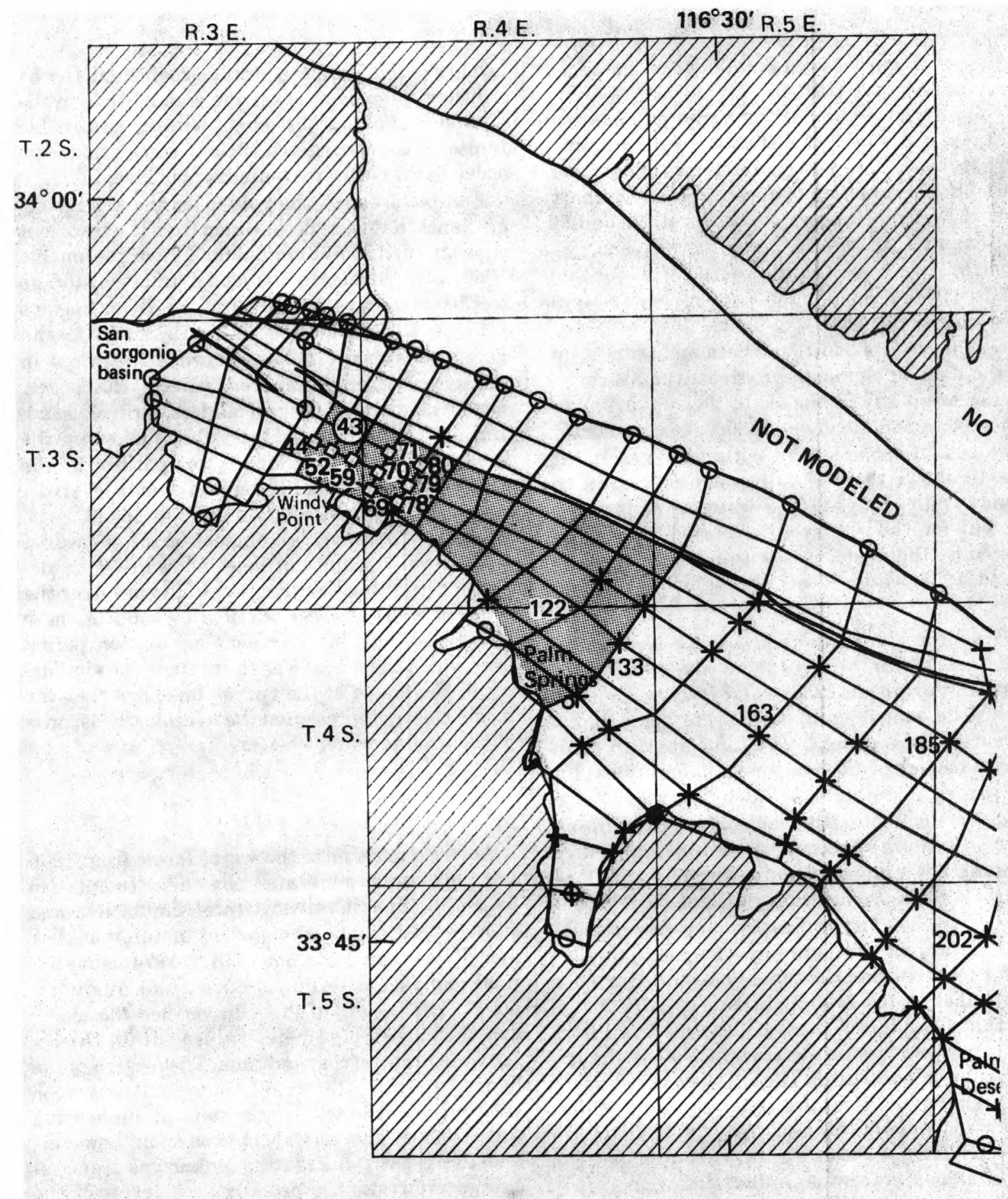

Figure 9.-Grid layout for digital flow model. 


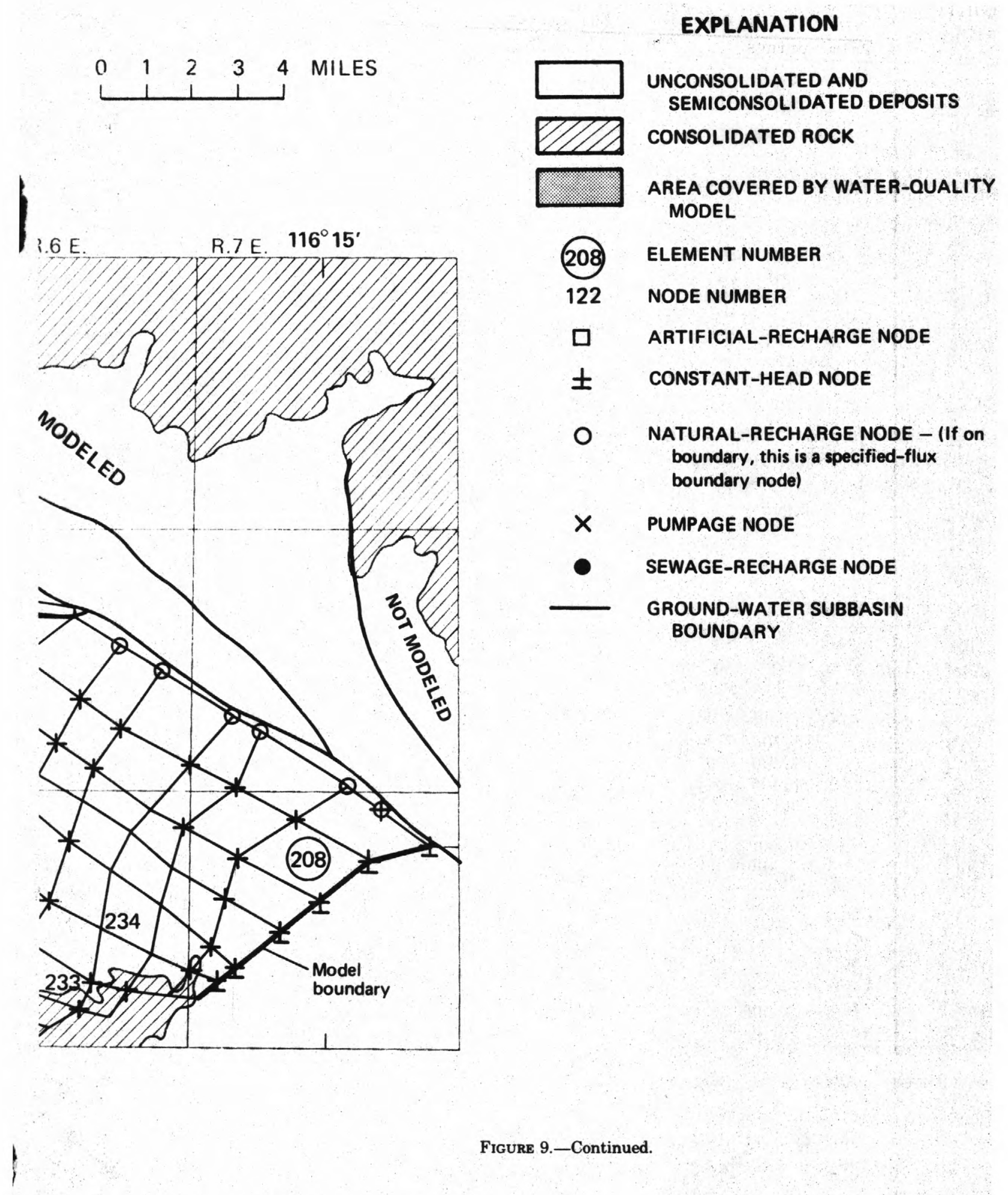


TABLE 1.-Steady-state ground-water recharge to Garnet Hill and Whitewater River subbasins

[Data modified from Tyley, 1974]

San (jorgonio River and underflow

Whit ewater River

Above White Water

Below White Water

Snow Creek

Fa11s Creek

Chino Creek at Chino Canyon

13,000

Tahquitz Creek

Andreas Creek at Andreas Canyon

4,000

8,000

1,000

1,100

1,500

2, 000

1,000

Palm Canyon

Deep Creek at Palm Desert

2,200

2,000

Total flow into Whitewater River subbasin

35,800

except for flow from Garnet Hill subbasin

Fst imated flow across Banning fault into Garnet Hill subbasin 2,000

\begin{tabular}{cc} 
Total & 37,800 \\
\hline
\end{tabular}

\section{FINITE-ELEMENT WATER-QUALITY MODEL}

The water-quality model chosen for this study also utilizes the finite-element numerical method of solution, but the equation solved is the masstransport equation for ion concentration distribution of a conservative constituent in an areal two-dimensional ground-water system. As described by Konikow and Bredehoeft $(1974$, p. 549) the equation solved is:

$$
\begin{array}{r}
\frac{\partial c}{\partial t}=\frac{\partial}{\partial x}\left(D_{x x} \frac{\partial c}{\partial x}\right)+\frac{\partial}{\partial x}\left(D_{x y} \frac{\partial c}{\partial y}\right)+\frac{\partial}{\partial y}\left(D_{y x} \frac{\partial c}{\partial x}\right)+ \\
\frac{\partial}{\partial y}\left(D_{y y} \frac{\partial c}{\partial y}\right)-\frac{\partial\left(V_{x} c\right)}{\partial x}-\frac{\partial\left(V_{y} c\right)}{\partial y}-\frac{c^{\prime} g}{b \theta}
\end{array}
$$

where

$$
V_{x}=\frac{T}{b \theta} \frac{\partial h}{\partial x}, V_{y}=\frac{T}{b \theta} \frac{\partial h}{\partial y}
$$

and $\quad b=$ saturated thickness of the aquifer, in this report assumed time independent (L) $c=$ mass per unit volume of solution of the constituent averaged over the aquifer thickness $\left(M L^{-3}\right)$

$c^{\prime}=$ mass per unit volume of solution of the constituent in the pumped or recharged solution $\left(M L^{-3}\right)$

$D_{x x}, D_{y y}, D_{x y}, D_{y x}=$ components of the effective hydrodynamic dispersion tensor. Derivation of these parameters from the longitudinal and transverse dispersion coefficients is explained by Scheidegger (1961) $\left(L^{2} T^{-1}\right)$

$h=$ hydraulic head $(L)$

$q=$ rate of fluid withdrawal or recharge $\left(L T^{-1}\right)$

$T=$ transmissivity $\left(L^{2} T^{-1}\right)$

$V_{y}$ and $V_{x}=$ average interstitial pore velocity $\left(L T^{-1}\right)$

$x, y=$ Cartesian coordinates $(L)$

$\theta=$ porosity (dimensionless). 


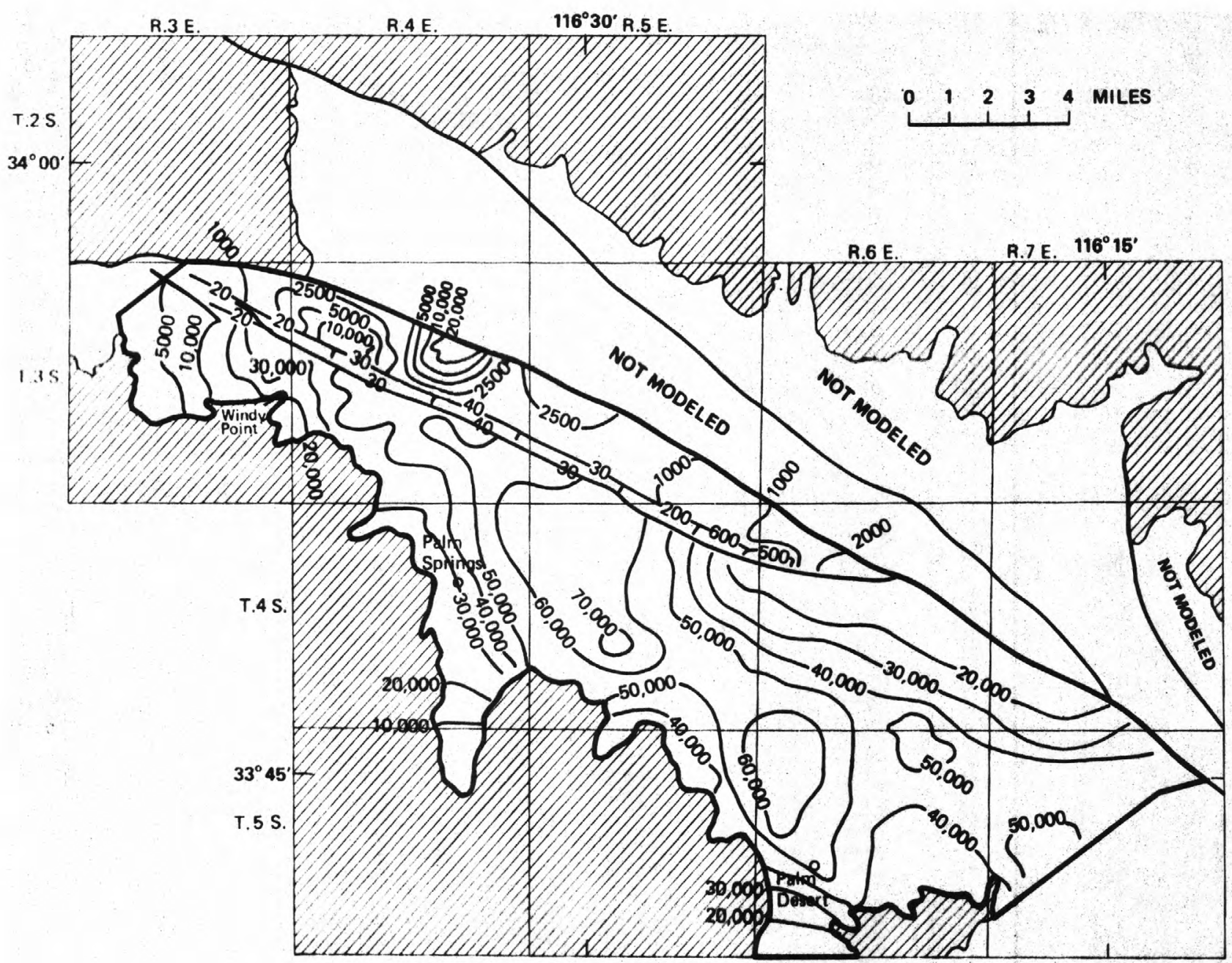

EXPLANATION

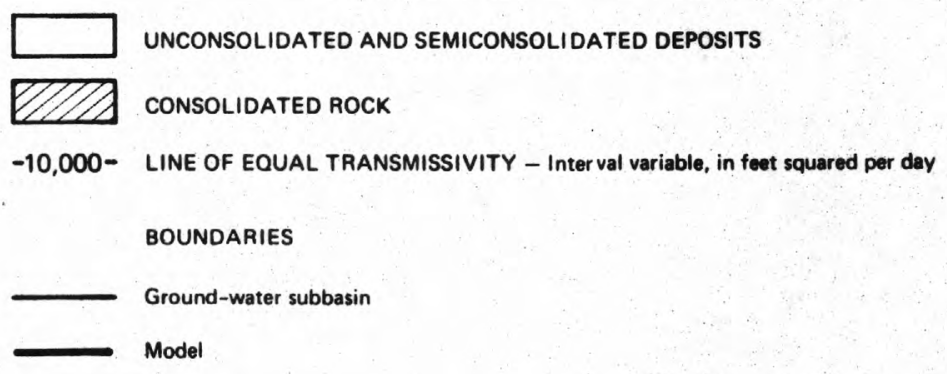

Figure 10.-Areal distribution of transmissivity as determined in the steady-state simulation. 
TABLE 2.-Annual net pumpage by subbasins and subareas, 1936-73

\begin{tabular}{|c|c|c|c|c|c|}
\hline \multirow[t]{2}{*}{ Year ${ }^{1}$} & \multirow{2}{*}{$\begin{array}{c}\text { Garnet Hill } \\
\text { subbasin } \\
\text { (acre-feet) }\end{array}$} & \multicolumn{4}{|c|}{$\begin{array}{l}\text { Whitewater River subbasin } \\
\text { (acre-feet) }\end{array}$} \\
\hline & & Palm Springs & Thousand Palms & Palm Desert & Indio \\
\hline 1936 & 0 & 30 & 1,170 & 3,240 & 250 \\
\hline 1937 & 0 & 30 & 1,200 & 3,370 & 295 \\
\hline 1938 & 0 & 30 & 1,240 & 3,470 & 295 \\
\hline $19 ; 9$ & () & 30 & 1,250 & 3,530 & 295 \\
\hline 1940 & 0 & 30 & 1,260 & 3,620 & 295 \\
\hline 1941 & 0 & 30 & 1,250 & 3,570 & 295 \\
\hline 1942 & 0 & 30 & 1,250 & 3,540 & 295 \\
\hline 1943 & 0 & 30 & 1,250 & 3,640 & 315 \\
\hline 1944 & 0 & 30 & 1,270 & 4,020 & 475 \\
\hline 1945 & 0 & 45 & 1,320 & 4,700 & 695 \\
\hline 1946 & 0 & 135 & 1,410 & 6,080 & 1,190 \\
\hline 1947 & 0 & 340 & 1,570 & 7,220 & 1,600 \\
\hline 1948 & 0 & 785 & 1,710 & 7,780 & 1,810 \\
\hline 1949 & 0 & 1,000 & 2,560 & 8,230 & 1,880 \\
\hline 1950 & 0 & 1,320 & 2,680 & 8,720 & 1,880 \\
\hline 1951 & 0 & 1,760 & 3,680 & 9,380 & 1,880 \\
\hline 1952 & 0 & 1,040 & 3,580 & 10,400 & 2,710 \\
\hline 1953 & 0 & 1,910 & 3,810 & 11,000 & 3,530 \\
\hline 1954 & 5 & 2,280 & 4,400 & 12,500 & 3,260 \\
\hline 1955 & 5 & 3,080 & 4,570 & 14,200 & 3,880 \\
\hline 1956 & 5 & 4,500 & 5,650 & 15,600 & 4,310 \\
\hline 1957 & 5 & 4,100 & 5,830 & 16,100 & 5,980 \\
\hline 1958 & 5 & 4,750 & 5,910 & 16,900 & 7,190 \\
\hline 1959 & 5 & 6,840 & 7,000 & 17,200 & 7,290 \\
\hline 1960 & 5 & 8,410 & 7,720 & 18,900 & 7,820 \\
\hline 1961 & 5 & 10,800 & 7,420 & 19,300 & 8,200 \\
\hline 1962 & 5 & 12,200 & 6,760 & 20,100 & 8,240 \\
\hline 1963 & 5 & 13,200 & 7,250 & 19,800 & 8,220 \\
\hline 1964 & 5 & 14,400 & 8,230 & 21,600 & 8,260 \\
\hline 1965 & 5 & 16,200 & 7,920 & 21,500 & 7,680 \\
\hline 1966 & 10 & 15,000 & 6,730 & 22,300 & 7,480 \\
\hline 1967 & 10 & 14,400 & 5,860 & 22,300 & 6,850 \\
\hline 1968 & 58 & 15,000 & 5,460 & 20,200 & 5,990 \\
\hline 1969 & 53 & 14,500 & 5,690 & 19,500 & 5,980 \\
\hline 1970 & 58 & 14,100 & 6,130 & 21,300 & 5,910 \\
\hline 1971 & 53 & 15,200 & 5,890 & 23,500 & 5,370 \\
\hline 1972 & 27 & 17,800 & 4,820 & 24,200 & 5,330 \\
\hline 1973 & 27 & 19,000 & 4,780 & 24,000 & 5,630 \\
\hline
\end{tabular}

1 1936-67 data from Tyley, 1974. 
TABLE 3.-Average annual natural ground-water recharge for transient-state simulation

[Data modified from Tyley, 1974]

\begin{tabular}{lc}
\hline \multicolumn{1}{c}{ Source } & $\begin{array}{c}\text { Recharge } \\
\text { (acre-feet per year) }\end{array}$ \\
\hline San Gorgonio River and underflow & 9,000 \\
Whitewater River & \\
Above White Water & 4,000 \\
Bclow White Water & 8,000 \\
Snow Creek & 2,700 \\
Falls Creek & 950 \\
Chino Creek at Chino Canyon & 2,000 \\
Andreas Creek at Andreas Canyon & 2,300 \\
Palm Canyon & 1,000 \\
Deep Creek at Palm Desert & 2,000 \\
Total flow into Whitewater River subbasin & 2,000 \\
$\quad$ except for flow from Garnet Hill subbasin & 33,950 \\
Estimated flow across Banning fault into Garnet Hill subbasin & 2,000 \\
\hline Total & 35,950 \\
\hline
\end{tabular}

TABLE 4. -Average annual sewage-effluent return from Palm Springs sewage-treatment plant

[From Tyley, 1974, p. 17]

\begin{tabular}{cc}
\hline Year & $\begin{array}{c}\text { Sewage-effluent return } \\
\text { (acre-feet per year) }\end{array}$ \\
\hline
\end{tabular}

$\begin{array}{rr}1936-51 & 0 \\ 1952-57 & 100 \\ 1958-62 & 250 \\ 1963-73 & 750\end{array}$

Because the model also uses the isoparametric quadrilateral elements (G. F. Pinder, written commun., 1975), it can readily be coupled to the data and the results from the flow model.

The water-quality model first computes the ground-water velocities from the water levels generated by the flow model. From the velocities calculated at each time step and from the dispersivity, the model calculates the water-quality conditions at each node for each time step. By comparisons of these values for progressive time steps, the movement of a chemical front or water-quality change within the aquifer may be traced.

Because the water quality of the upper Coachella ground-water basis has been nearly unchanged since the first chemical-quality data were collected in 1938, the calibration of the model in the study area is not possible at this time. The model program, however, was previously tested extensively with data from the Long Island aquifer system (Pinder, 1973; Pinder and Page, 1977). The hydrologic-parameter values, which had previously been verified in the Coachella Valley flow model, were transferred and used in the water-quality model with the only new parameters being porosity, dispersivity, and average dissolved-solids concentration of aquifer water. 


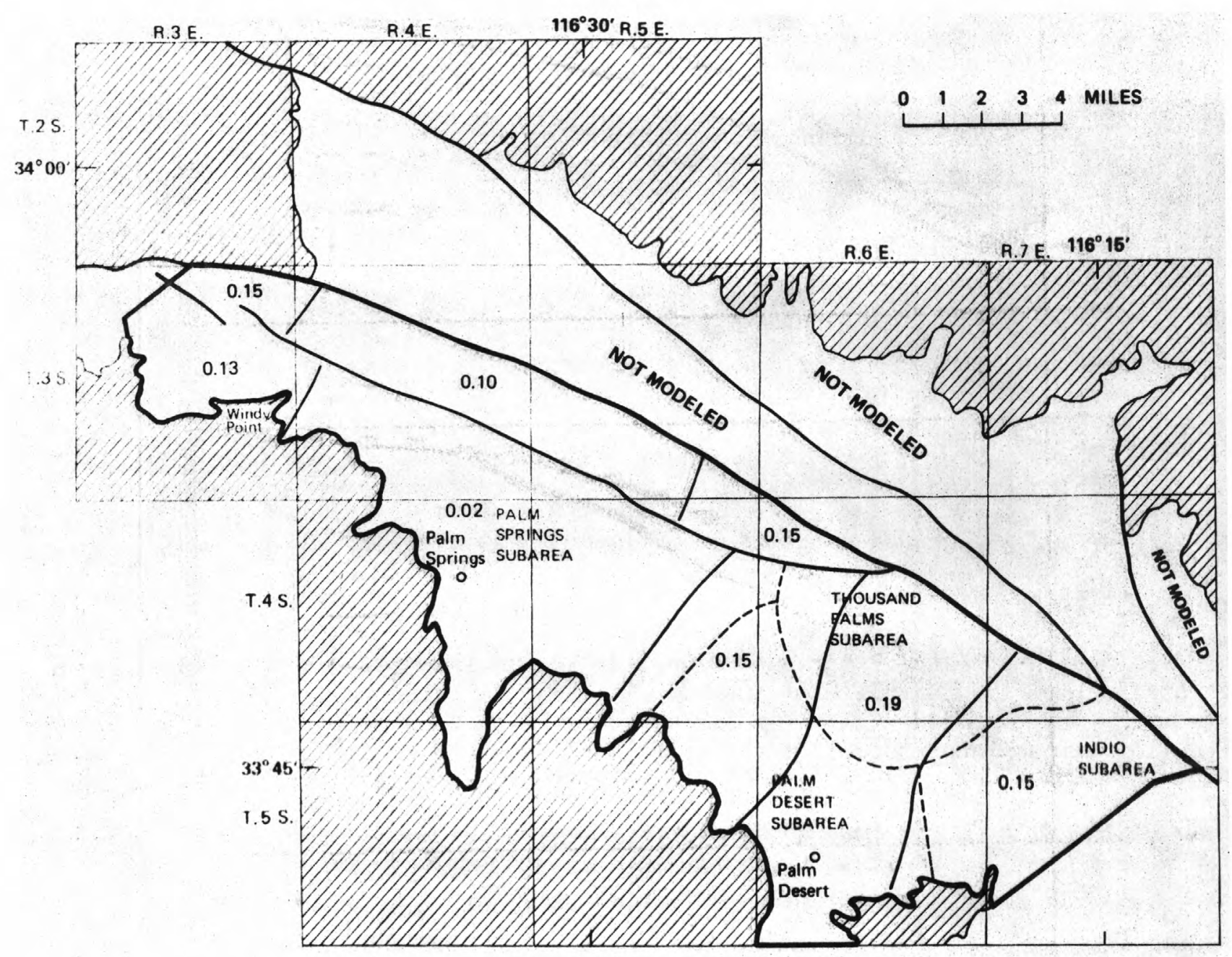

EXPLANATION

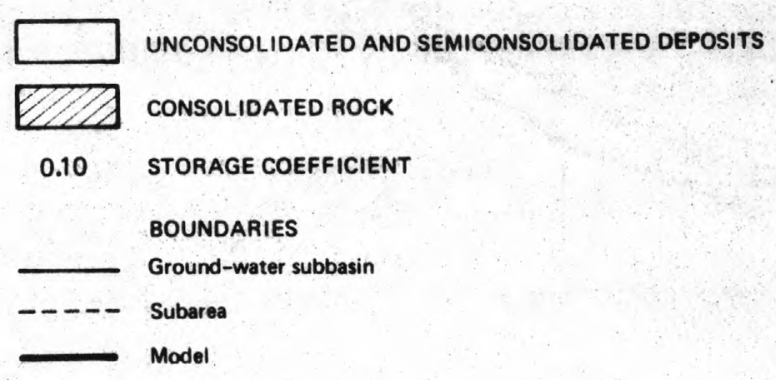

Figure 11.-Model-generated values for storage coefficients. 


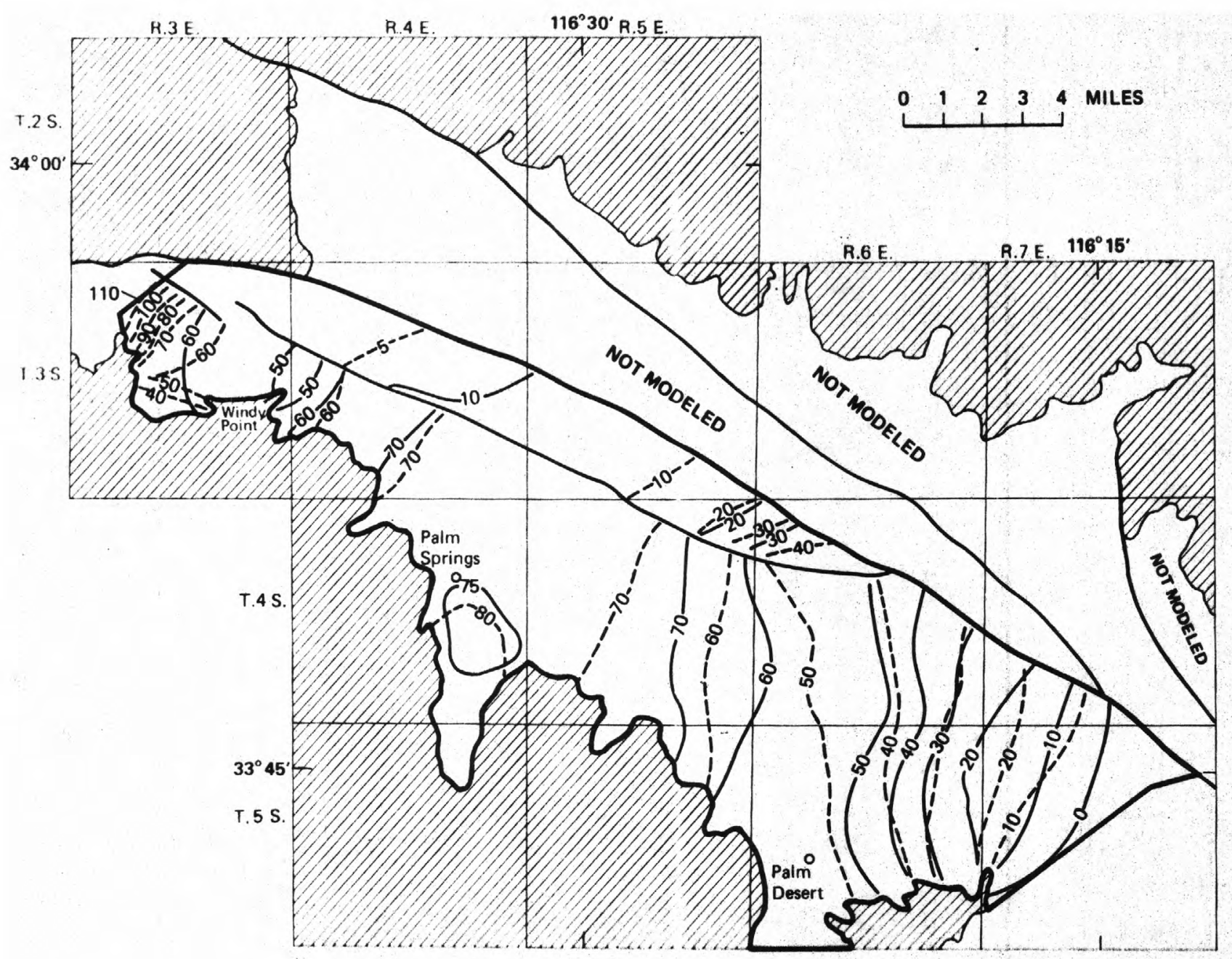

EXPLANATION

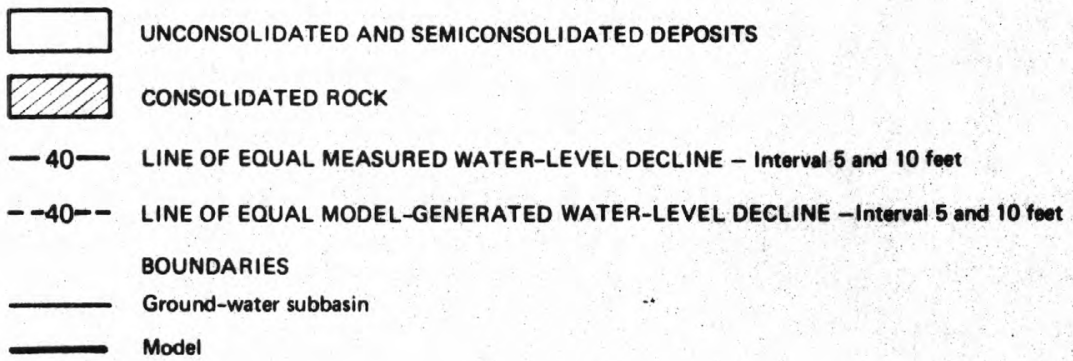

FigURE 12.-Comparison of measured and model-generated water-level decline, 1936-68. 

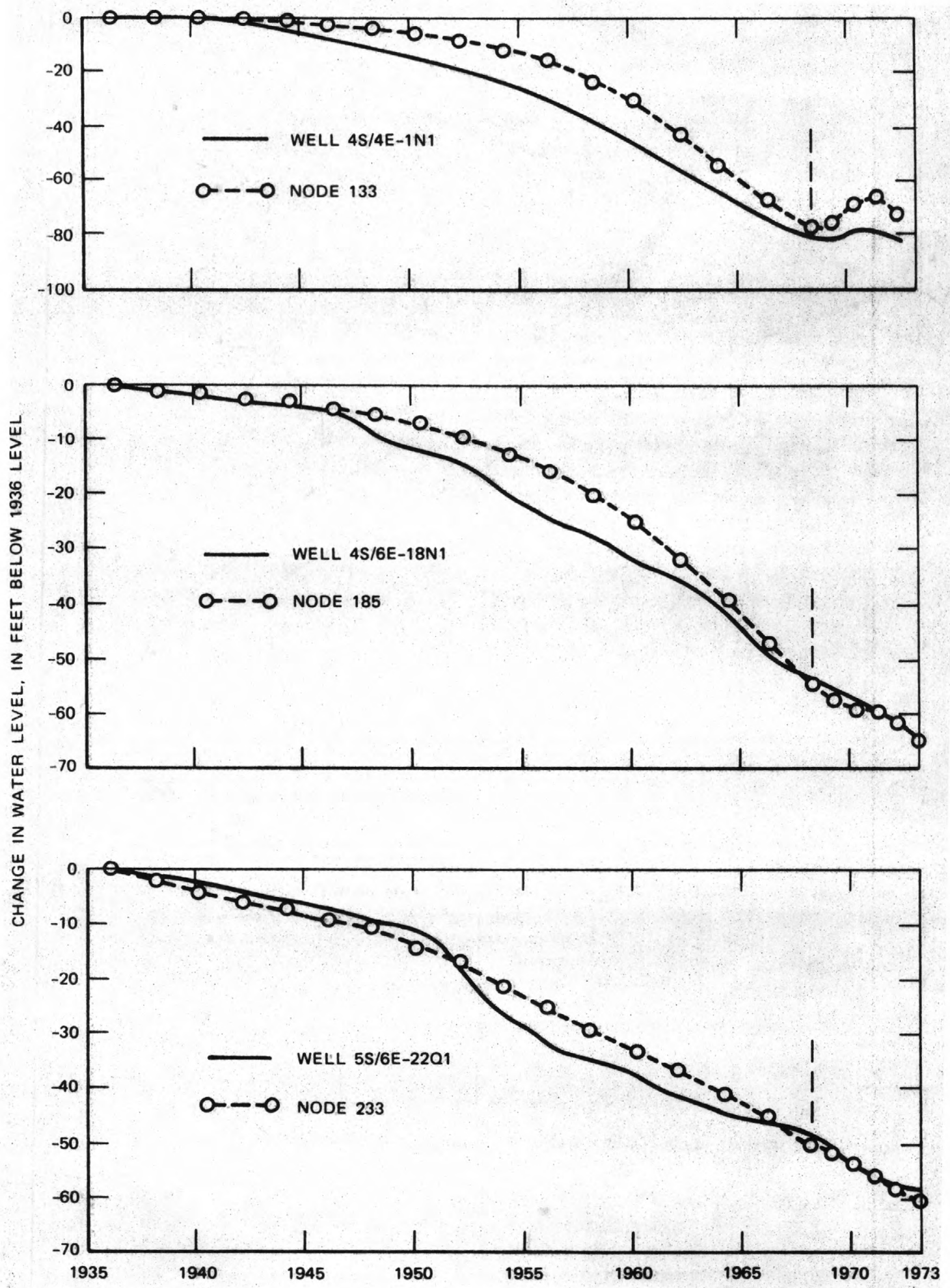

Figure 13. - Comparisons of hydrographs generated by digital flow model (dashed lines) versus historical measured water levels (solid lines). Location of nodes shown in figure 9. 
B(I) NIARY (ONI)II INS

Even though the water-quality model is within the flow-model boundaries (figs. 9 and 14), the boundary conditions are somewhat different. The south side of the water-quality model, which is bounded by impermeable consolidated rocks, was considered a no-flow boundary. Because of the vory low trinsminsivity (30) $\mathrm{fl}^{2} / \mathrm{d}$ ) the (inmet ollill fault zone along the northeast of the waterquality model was also considered a no-flow boundary.

On the east and the west ends of the model, the water levels fluctuate in response to stresses of recharge or pumpage outside the immediate water-quality model area. Because the water levels at both ends of the model are known from the flow model for each time step, these levels can be specified in the water-quality model at each time step. Thus, the two ends can be considered prescribed-head boundaries that change with time because of water-level changes in the flow model. For example, if the water level declined in the flow model for the Palm Springs subarea, the decline might be reflected at the east boundary of the water-quality model.

In the water-quality model, in addition to the hydrologic boundary conditions, ion-concentration boundary conditions must also be considered. The west end of the area was considered a constant ion-concentration boundary because it receives recharge water of a constant ion concentration from outside the model area. All other ionconcentration boundaries around the model area were considered constant diffusive-flux boundaries where the concentration gradient normal to the boundary was zero.

\section{(;RII) I.AYOLI}

When water is recharged to a ground-water system, water levels are affected over a large area because the pressure from the weight of the recharge water is transmitted throughout the aquifer. The area over which the actual solutes in the recharged water are dispersed, however, is small in comparison. Thus, a much smaller and more detailed area is often used for a waterquality model than for a flow model. In the upper Coachella Valley, the greatest interest in waterquality change is in the area of artificial recharge and immediately downgradient. Thus, the water-quality-model grid covers only a small part of the original flow-model grid (fig. 9). This smaller model (fig. 14) consists of 360 nodes and 312 elements covering an area of only about 20 $\mathrm{mi}^{2}$ in the northwest end of the Whitewater River subbasin. The areas of the largest and smallest elements are 0.2 and $0.015 \mathrm{mi}^{2}$, respectively.

\section{M(I)LLI, PAKAMEILRS}

In addition to the hydrologic-data input and water-level results from the flow model, the water-quality model requires ion-concentration values for each node plus hydrodynamic dispersion, porosity, and saturated thickness for each element.

Ion concentration.-Dissolved-solids concentration was chosen to be simulated by the waterquality model because it is a conservative solute for which sufficient reliable data are available for the study area. Not only has the concentration remained almost unchanged since the 1930 's, but the distribution of dissolved-solids concentration has remained generally the same over the model area. Thus, a concentration of $210 \mathrm{mg} / \mathrm{L}$ was programed into the model as the present and initial concentration over the model area. Compared against this uniform initial concentration, any variance in concentration would show movement of water of a different quality.

Hydrodynamic dispersion.-Hydrodynamic dispersion is a parameter that determines the extent to which the dissolved minerals in the incoming water will be spread out or dispersed because of mixing with the aquifer water. This mixing results from both molecular diffusion and nonuniform velocities that occur in the aquifer principally as a result of varied flow paths in the pore space. Thus, some of the incoming water may be retarded in its movement in the aquifer, and some of the water may move at a greater than average ground-water velocity. Without dispersion the incoming water would move through the aquifer as a sharp distinct front.

Dispersion is dependent upon velocity and dispersivity by the relation:

$$
D=d v
$$

where

$$
\begin{aligned}
& D=\text { hydrodynamic dispersion }\left(L^{2} T^{-1}\right) \\
& d=\text { dispersivity }(L) \\
& v=\text { velocity }\left(L T^{-1}\right)
\end{aligned}
$$




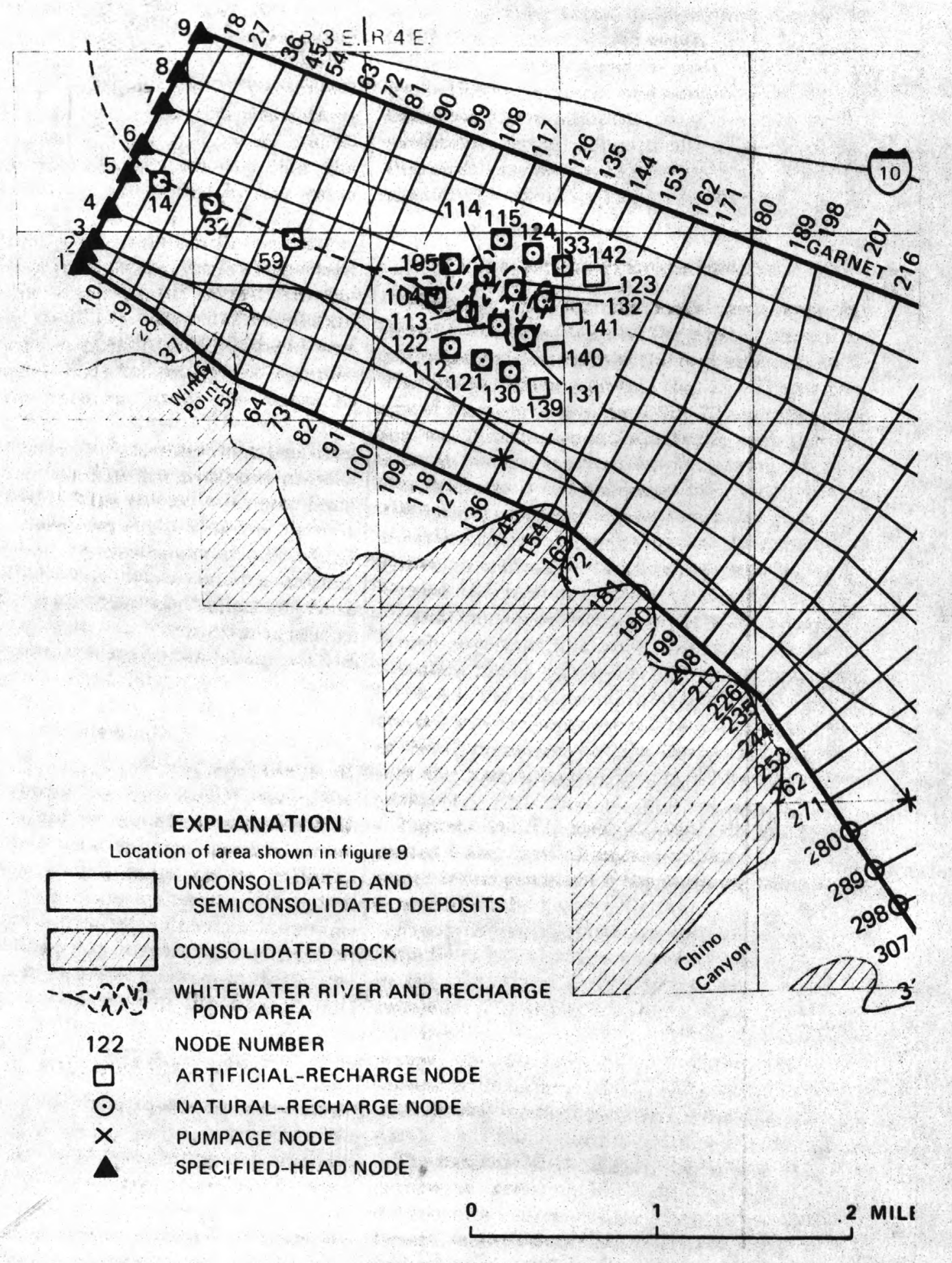

FIGURE 14.-Grid layout for water-quality model. 


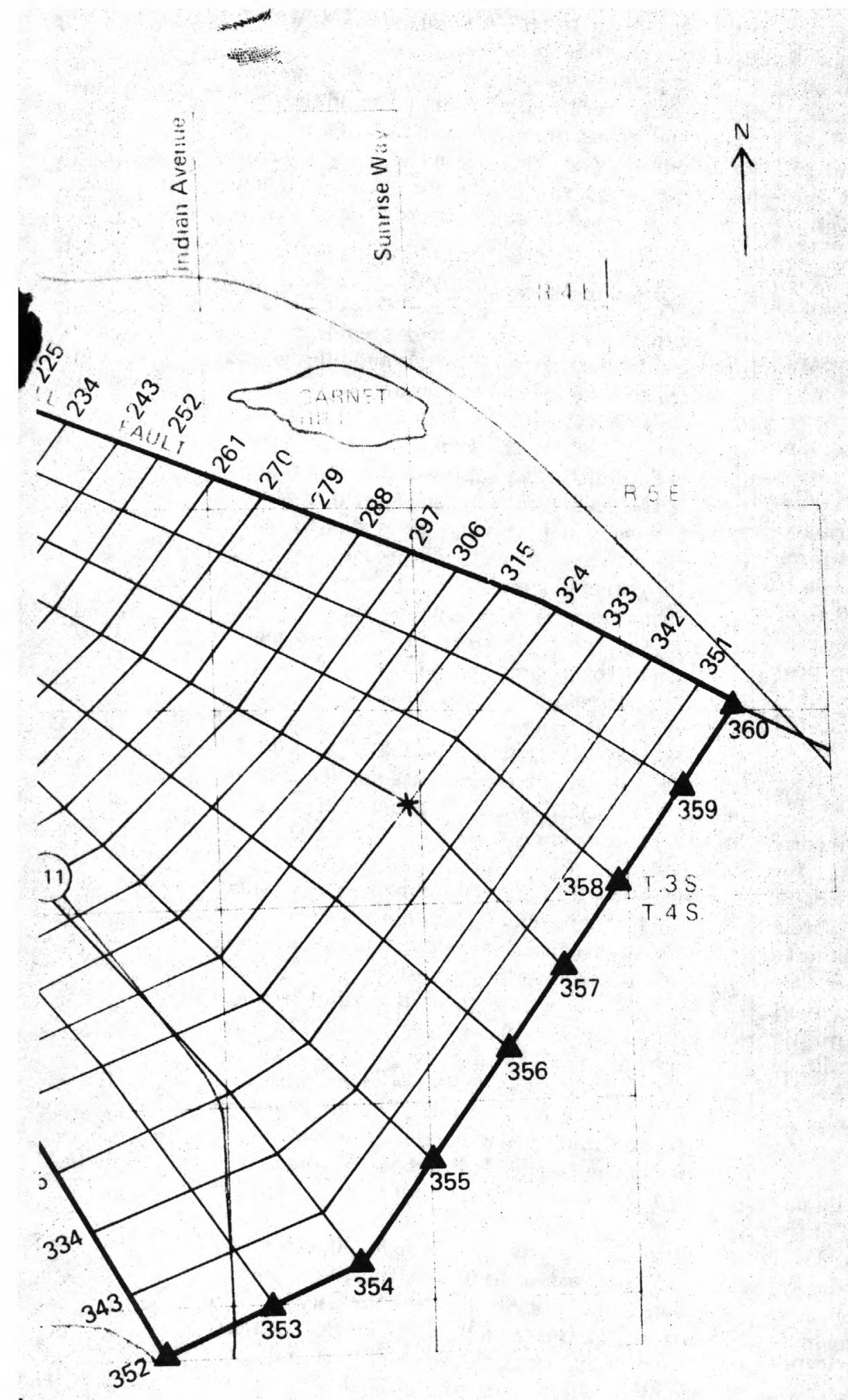

Figure 14.-Continued. 
The longitudinal and transverse dispersivities used in the model were 100 and $33 \mathrm{ft}$, respectively. These values were used in other model studies with similar aquifer material (Robson, 1974; Konikow and Bredehoeft, 1974; Bredehoeft and Pinder, 1973). In later predictive simulations a comparison of results using half, twice, and 10 times the dispersivity values showed that the results were relatively unaffected by the value chosen.

Porosity.-Because the ground-water velocity is a direct function of the porosity, it is an important parameter in the water-quality model. On the basis of recharge studies by Tyley (1973) and data from drillers' logs, a porosity of 25 percent was used in the model. Data on porosity of samples obtained for the recharge study are listed in table 5 .

Saturated thickness. - Saturated thickness used in the model was based on the available gravity data (Biehler, 1964). This thickness ranged from $750 \mathrm{ft}$ in the western part of the model to $1,000 \mathrm{ft}$ in the eastern part. A maximum of $1,000 \mathrm{ft}$ of saturated thickness was chosen more as an economic pumping limit than an actual physical boundary because depth to bedrock is probably more than $1,000 \mathrm{ft}$ below land surface over most of the study area.

\section{(AI.IBRATION}

Because there has been no significant temporal water-quality change in the model area, the water-quality model is, in effect, uncalibrated until such a time that quality changes occur which would serve as a check on its validity. Based upon the hydrologic information from the verified flow model and water-quality data available from measurements and the literature, the model is useful as a tool for prediction but its degree of accuracy is uncertain at this time.

\section{FLOW-MODEL PREDICTIONS}

Having achieved the reasonable fit of the past and present water-level conditions, the calibrated flow model may be used to predict the water levels that would result from stresses placed on the system, whether they be pumpage, recharge, or changes in inflow or outflow. Because the population is increasing in the upper Coachella Valley, the first test was to determine the effects of predicted pumping stress on the water levels. The effect of recharging the aquifer with the imported water was then tested to determine the waterlevel changes that would result.

These predictions can be only as good as the predictions of recharge and pumpage and they are based on the assumption that average natural conditions prevail. Thus if any of these controlling conditions are in substantial error, the model predictions would be subject to revision.

\section{PREDICTED PUMPAGE EFFECTS}

Pumping rates for the model area were projected by the extension of the plotted annual net pumpage data for each of the four subareas in the Whitewater River subbasin (fig. 15). The percentage of increase above the 1968-73 average pumpage was determined and applied to each pumping node in the model area for the period specified. The decrease in net pumpage from about 1965 to 1968 was principally due to a decrease in agricultural irrigation as much of the irrigated land either was changed to urban or was no longer farmed. For the predictive phase of the model simulation, three time periods were chosen for which projected pumpage would be allotted to simulate future water levels. These periods were: 1974-80, 1981-90, and 1991-2000. Table 6 lists the percentage pumpage increase applied for each of the three periods for the Garnet Hill subbasin and the four subareas of the Whitewater River subbasin.

Figures 16, 17, and 18 show the model-generated water-level changes compared to the 1974 water levels predicted if the pumping rates are as projected in the graphs (fig. 14).

Figure 16 indicates a maximum water-level decline from 1974 conditions of about $40 \mathrm{ft}$ by 1981 in the vicinity of Palm Springs as a result of pumping. The indicated decline near Palm Desert, however, is only about $20 \mathrm{ft}$ for the same period. For the 1974-81 period, the water-level decline in the Garnet Hill subbasin ranges from $10 \mathrm{ft}$ in the western part to $30 \mathrm{ft}$ in the eastern part.

The model predicts (fig. 17) 1974-90 water-level declines as great as $120 \mathrm{ft}$ in the Palm Springs subarea and about $60 \mathrm{ft}$ in the vicinity of Palm Desert. In the Garnet Hill subbasin the predicted decline is only $20 \mathrm{ft}$ in the western part and about $70 \mathrm{ft}$ in the eastern part where the deposits in the fault zone are more permeable. 
TABLE 5.-Porosity values from water-quality model area

[From Tyley, 1973]

\begin{tabular}{|c|c|c|c|}
\hline $\begin{array}{l}\text { Laboratory } \\
\text { sample } \\
\text { number }\end{array}$ & $\begin{array}{l}\text { Location of } \\
\text { sample }\end{array}$ & $\begin{array}{c}\text { Depth below } \\
\text { land surface } \\
\text { (feet) }\end{array}$ & $\begin{array}{l}\text { Total porosity } \\
\text { (percent) }\end{array}$ \\
\hline 3 & Windy point area & $5-7$ & 21.0 \\
\hline 4 & do. & $10-12$ & 25.5 \\
\hline 5 & do. & $25-27$ & 22.7 \\
\hline 1 & $\begin{array}{l}\text { Approximately } \\
3 \text { miles down- } \\
\text { valley from } \\
\text { Windy Point }\end{array}$ & $16-18$ & 23.5 \\
\hline 2 & do. & $20-22$ & 29.0 \\
\hline
\end{tabular}

TABLE 6.-Average increase in net pumping rate for simulation periods

\begin{tabular}{|c|c|c|c|c|}
\hline \multirow{2}{*}{ Area } & \multirow{2}{*}{$\begin{array}{c}\text { Average } \\
\text { pumping } \\
\text { rate } \\
1968-73 \\
\text { (acre-feet } \\
\text { per year) }\end{array}$} & \multicolumn{3}{|c|}{$\begin{array}{l}\text { Percentage increase } \\
\text { above } 1968-73 \text { rate }\end{array}$} \\
\hline & & $1974-80$ & $1981-90$ & $1991-2000$ \\
\hline $\begin{array}{l}\text { Garnet Hill subbasin } \\
\text { Whitewater River subbasin }\end{array}$ & 47 & 50 & 100 & 150 \\
\hline Palm Springs subarea & 15,930 & 45 & 120 & 185 \\
\hline Palm Desert subarea & 22,090 & 35 & 60 & 90 \\
\hline Indio subarea & 5,700 & 22 & 40 & 67 \\
\hline Thousand Palms subarea & 5,460 & 10 & 25 & 40 \\
\hline
\end{tabular}

The predicted 1974-2000 water-level decline in the vicinity of Palm Springs is as much as $200 \mathrm{ft}$ and in the vicinity of Palm Desert as much as 100 $\mathrm{ft}$ (fig. 18). The Garnet Hill subbasin water-level decline during this period is predicted to be from 20 to $140 \mathrm{ft}$.

The significance of these model simulations with the projected pumping rates is that, even though it took from 1936 to 1974 for the water level to decline $100 \mathrm{ft}$ in the Palm Springs subarea, it will have declined an additional $100 \mathrm{ft}$ by
1991 and another $100 \mathrm{ft}$ by 2000 . Thus, without artificial recharge the water level in the Palm Springs area will have been lowered about $300 \mathrm{ft}$ from the 1936 levels by the year 2000 . This condition will leave some wells dry, decrease the yield in other wells, and increase the cost of pumping because of the increased lift required to bring the water to the land surface. To retard this decline and stabilize or raise the water levels, the local water agencies decided to recharge the groundwater basin with imported water. 

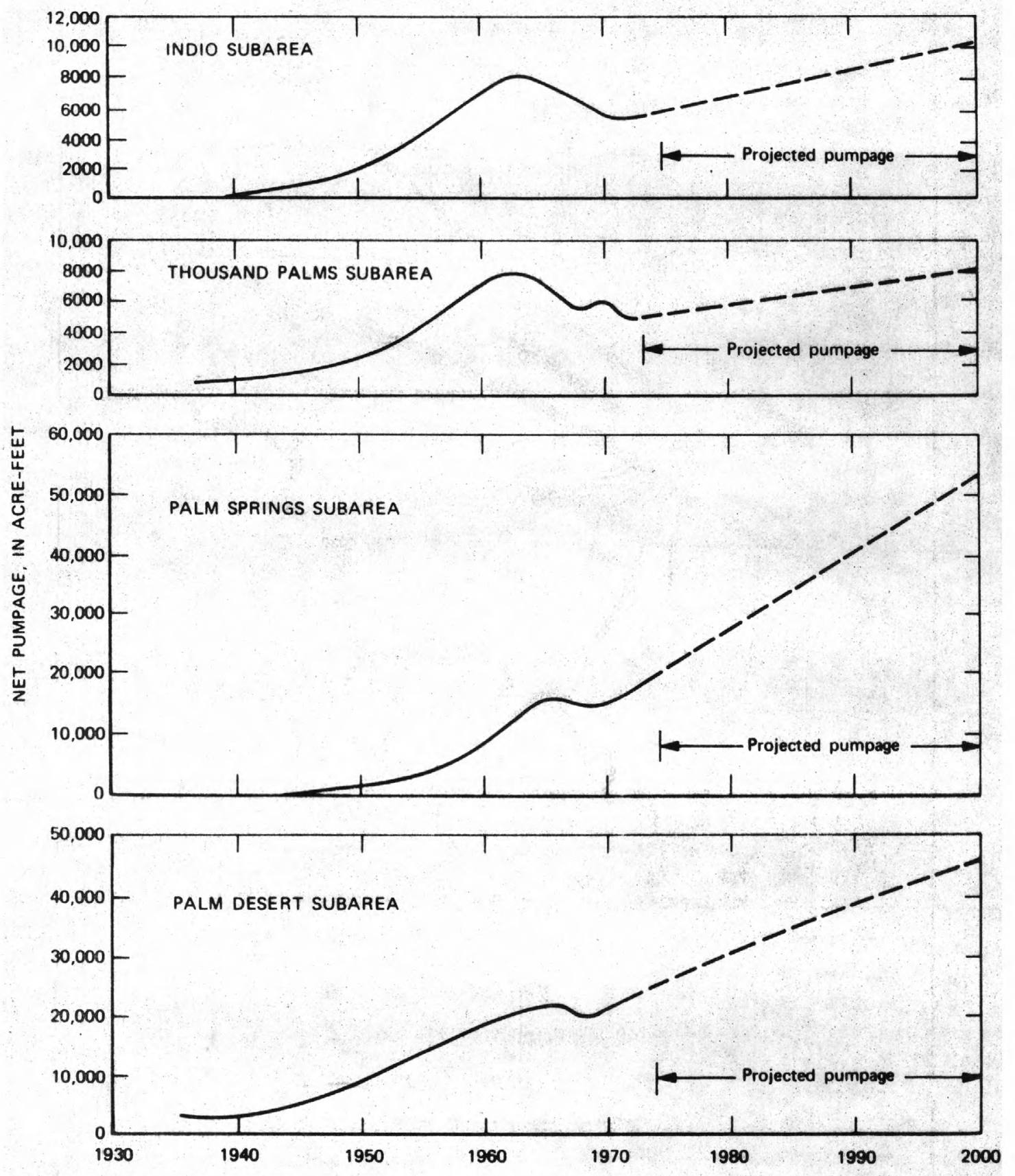

FIGURE 15.-Past and projected net pumpage for subareas within Whitewater River subbasin, 1936-2000. 


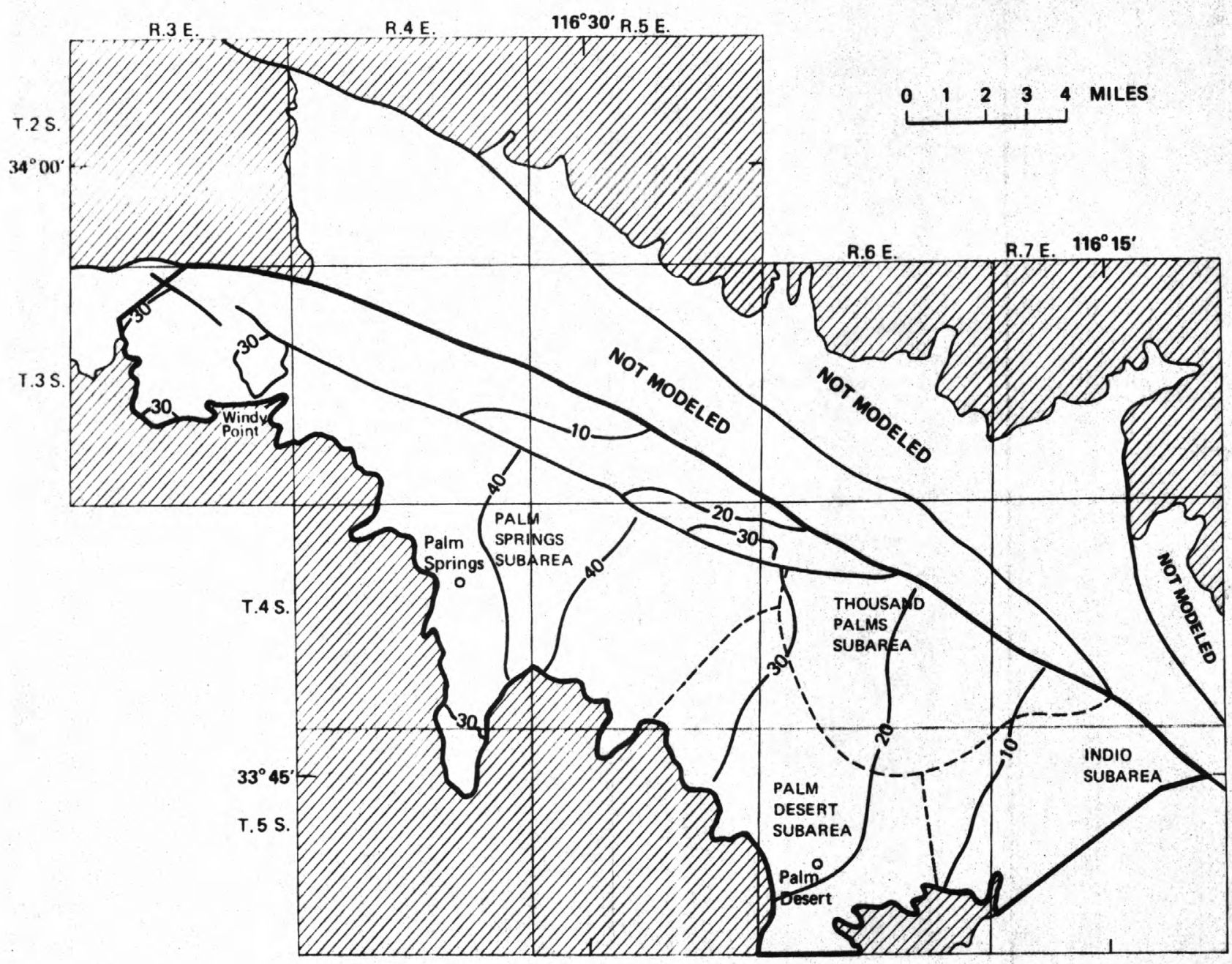

EXPLANATION

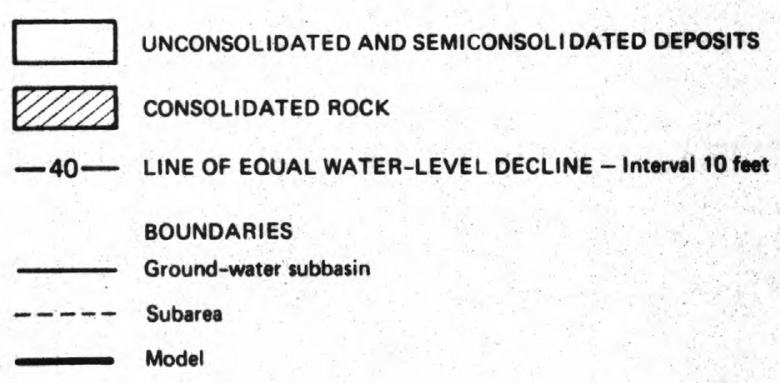

FIGURE 16.-Model-projected 1974-80 water-level decline with projected pumpage-no artificial recharge. 


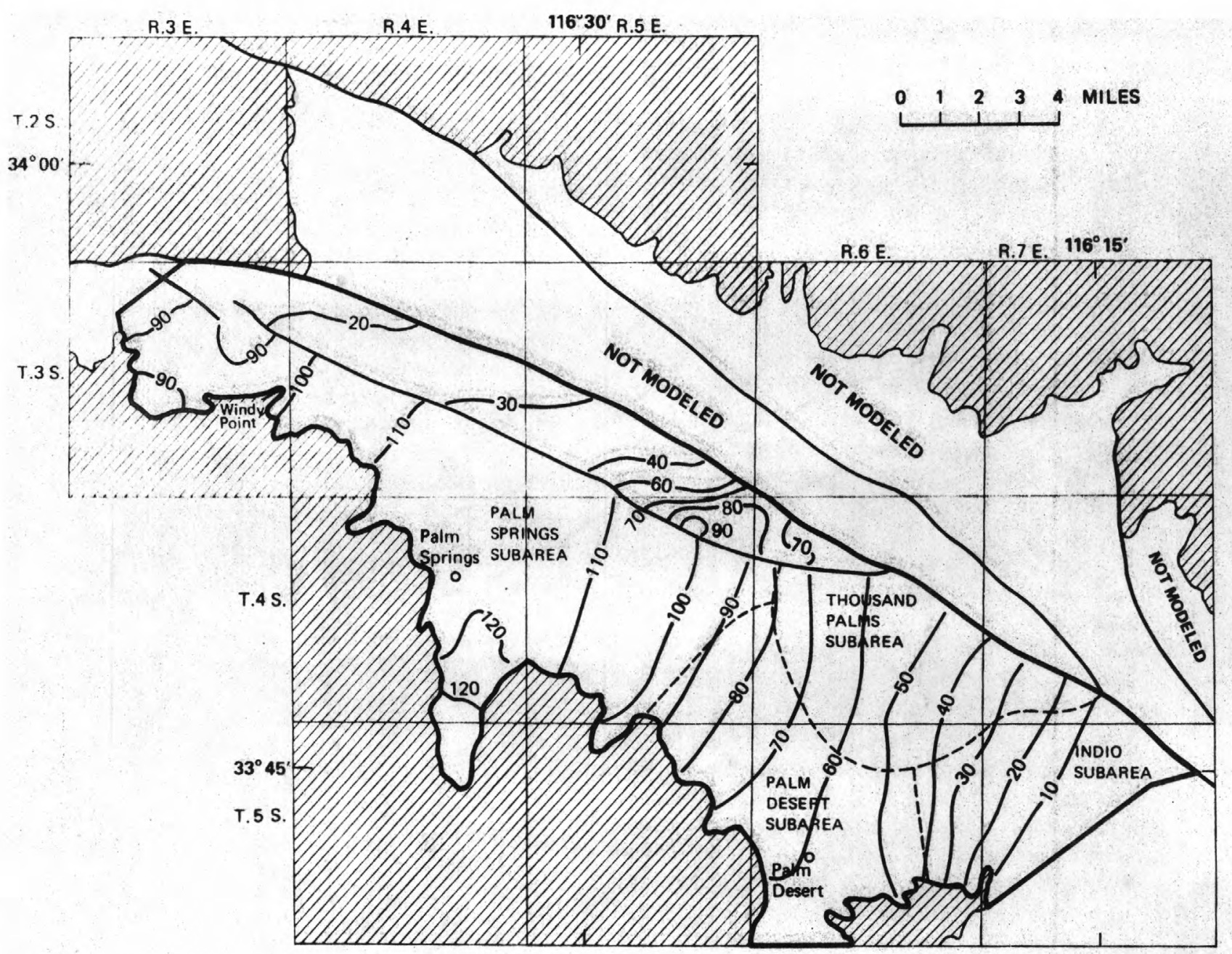

EXPLANATION

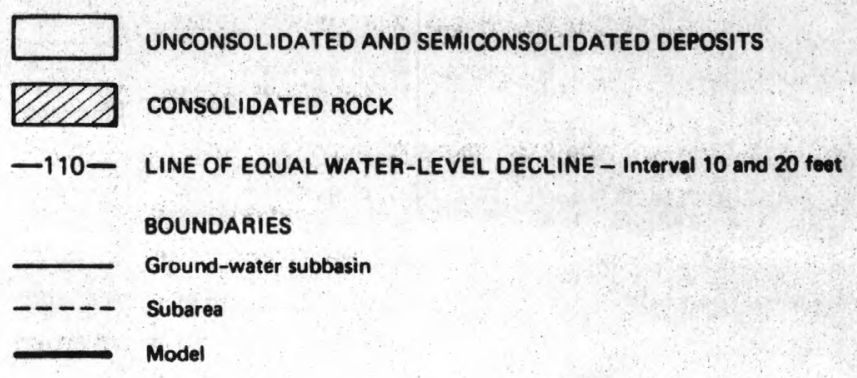

Figure 17.-Model-projected 1974-90 water-level decline with projected pumpage-no artificial recharge. 


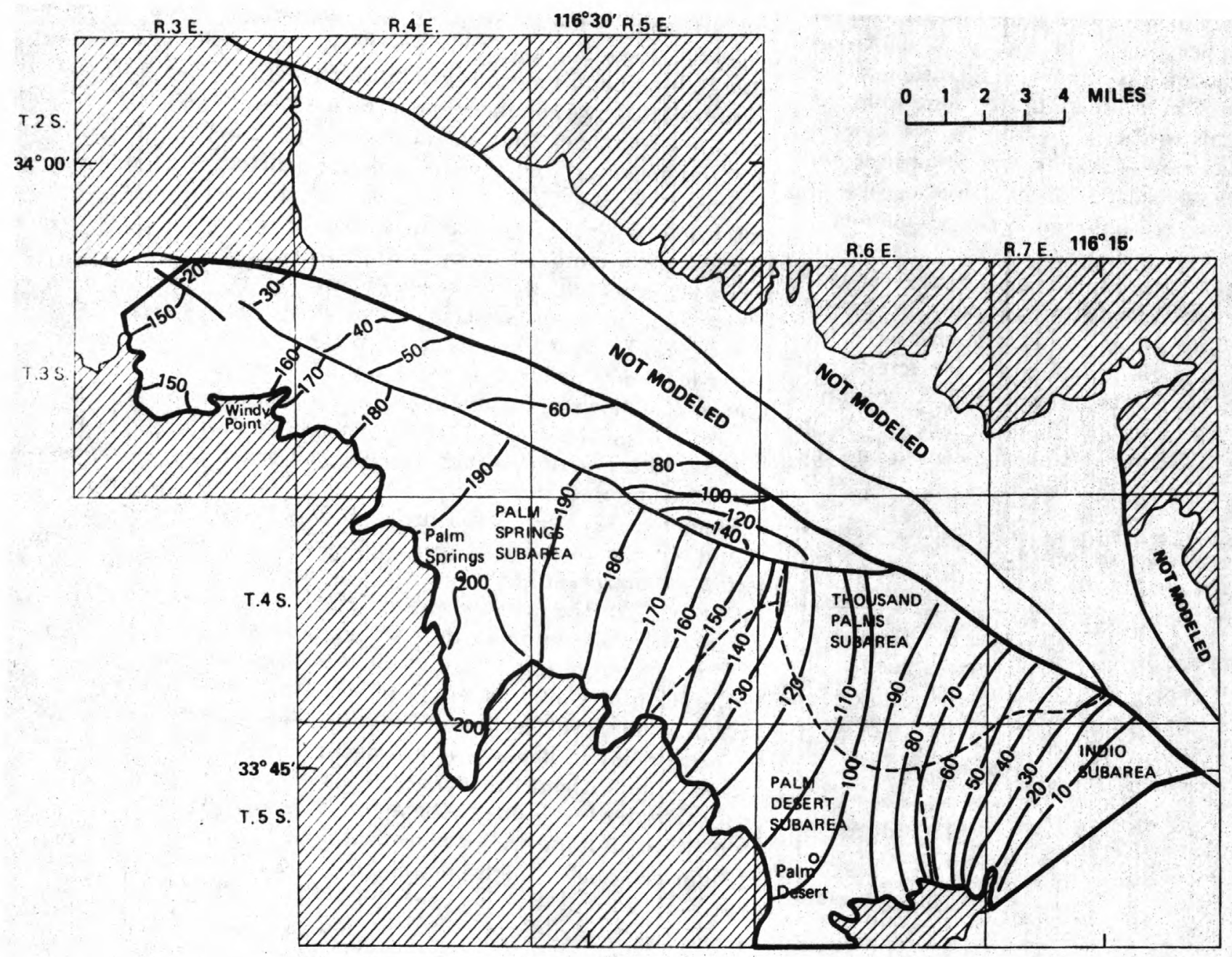

EXPLANATION

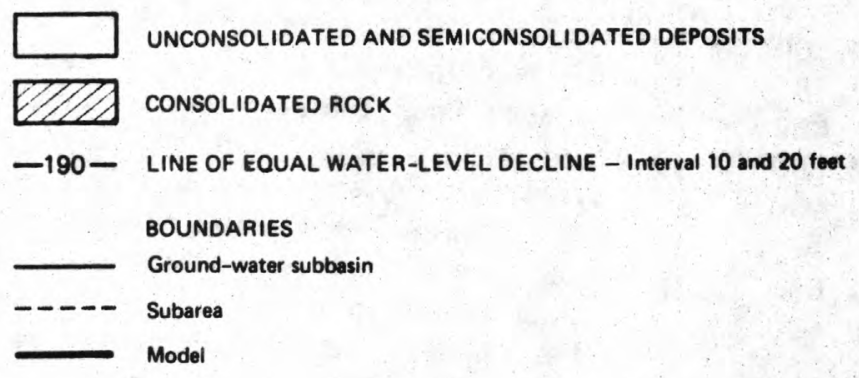

FiGURE 18.-Model-projected 1974-2000 water-level decline with projected pumpage-no artificial recharge. 


\section{PRFIIIC:TF,I) AR'TIFICIAL,-RECHARGE, EFFECTS}

The quantity of water available for artificial recharge to upper Coachella Valley is shown in table 7. Although the time of infiltration of the recharge water in the unsaturated zone from the recharge ponds to the water table is not known, an infiltration rate of 1 year from pond to water table was chosen on the basis of hydrograph or water-level lag response after periods of heavy rain or flooding.

On the basis of the surface area of the recharge pond and channel and of the evaporation rate of about $7 \mathrm{ft}$ during the period when water is recharged, it was estimated that 500 acre-ft per year may be lost to evaporation from the channel and pond area.

With the recharge lag time considered and the

TABLE 7.-Upper Coachella Valley annual entitlements to water from State Water Project through year 2000

\begin{tabular}{cc}
\hline Year & $\begin{array}{c}\text { Total volume } \\
\text { (acre-feet) }\end{array}$ \\
\hline 1973 & 17,475 \\
1974 & 115,396 \\
1975 & 110,823 \\
1976 & 19,600 \\
1977 & 21,400 \\
1978 & 23,200 \\
1979 & 25,100 \\
1980 & 27,900 \\
1981 & 31,100 \\
1982 & 34,300 \\
1983 & 37,500 \\
1984 & 40,800 \\
1985 & 44,000 \\
1986 & 47,200 \\
1987 & 50,900 \\
1988 & 54,600 \\
1989 & 58,400 \\
1990 and after & 61,200 \\
\hline
\end{tabular}

\footnotetext{
${ }^{1}$ Measured amount released to Whitewater River channel.
}

estimated evaporation subtracted from the allotted amount of imported water, the average annual artificial recharge for the three time periods (1974-80, 1981-90, and 1991-2000) was calculated (table 8 ) and programed into the model.

Figure 19 shows the model-generated 1974-80 water-level changes that would result from the artificial recharge and the previously predicted pumpage. Under these stresses a maximum water-level decline of $20 \mathrm{ft}$ occurs near Cathedral City. In the vicinity of Palm Springs where the water-level decline would be $40 \mathrm{ft}$ without recharge (fig. 16), with artificial recharge the decline would be only $10 \mathrm{ft}$. Near Palm Desert, the water-level decline with recharge would be $17 \mathrm{ft}$. Figure 20 shows the difference in 1981 water levels between the projected pumpage-only simulation and the artificial recharge and projectedpumpage simulation.

Predicted 1974-90 water-level changes that would occur with artificial recharge and the projected pumpage for that period are shown in figure 21. At the location near Palm Springs where the maximum decline would be $120 \mathrm{ft}$ without recharge (fig. 17), the 1974-90 decline, with recharge, would be only $20 \mathrm{ft}$. At Palm Desert, a water-level decline of $40 \mathrm{ft}$ would result with artificial recharge where a decline of $60 \mathrm{ft}$ would occur without the recharge. The difference in 1991 water levels due to the artificial recharge from 1974 through 1990 is shown in figure 22.

Figure 23 shows the total water-level changes that would occur by the year 2000 from 1974 levels due to artificial recharge and projected pumpage. With recharge the 1974 water levels near Palm Desert will have declined about $60 \mathrm{ft}$ by 2000 . In the vicinity of Palm Springs, where a maximum decline of $200 \mathrm{ft}$ would occur without recharge, the water level would rise to about the 1974 level (altitude $180 \mathrm{ft}$ ) by the year 2000 with recharge. These total declines, as compared to the pumpage-only water levels (fig. 18) for the same period, actually show a $40-\mathrm{ft}$ difference in water level in Palm Desert subarea and 170-ft difference in Palm Springs subarea as a result of the artificial recharge (fig. 24).

Four nodes $(122,163,202$, and 234 shown in fig. 9) located progressively downstream from the recharge area were selected to indicate the water-level changes that would occur at a specified location as a result of artificial recharge or no recharge. The hydrographs for these four 
TABLE 8.-Average annual artificial recharge as applied at nodes of flow model

\begin{tabular}{crrr}
\hline \multirow{2}{*}{$\begin{array}{c}\text { Node number } \\
\text { (fig. 9) }\end{array}$} & \multicolumn{3}{c}{$\begin{array}{c}\text { Rate of recharge } \\
\text { (acre-feet per year) }\end{array}$} \\
\cline { 2 - 4 } & $1974-80$ & $1981-90$ & $1991-2000$ \\
\hline 44 & 1,000 & 2,000 & 2,000 \\
52 & 1,000 & 2,000 & 3,000 \\
59 & 1,000 & 3,000 & 4,000 \\
69 & 400 & 400 & 200 \\
70 & 3,000 & 5,000 & 7,000 \\
71 & 300 & 400 & 200 \\
78 & 3,000 & 5,000 & 7,000 \\
79 & 6,000 & 18,000 & 32,000 \\
80 & 1,000 & 3,000 & 5,000 \\
\hline Total annual recharge & 16,700 & & 60,400 \\
\hline
\end{tabular}

nodes (fig. 25) show the water-table response with time under each of the following conditions: (1) Historical pumpage, (2) projected pumpage only, and (3) projected artificial recharge and pumpage. Comparison of the hydrographs shows the greatest decline in water level, due to pumpage only, would be in the upper end of the valley (nodes 122 and 163). In addition, the greatest water-level response to artificial recharge would also occur in the upper end of the valley.

Figure 20 shows that by 1981 artificial recharge will have affected water levels over most of the Whitewater River subbasin extending as much as $20 \mathrm{mi}$ southeast of the recharge site. These distant water-level changes are due to the relatively rapid rate of transmission of increases in hydrostatic pressure produced by the quantity of water recharging the aquifer and not to the physical movement of the artificially recharged water to the point of water-level rise. As time passes, some of the artificially recharged water would mix with the native ground water near the point of recharge and move slowly southeast, down the valley. The water-quality model is a tool that can be used to estimate how rapidly artificial-recharge water will physically move within the aquifer.

\section{WATER-QUALITY MODEL PREDICTIONS}

As defined earlier, it is assumed that the dissolved-solids concentration in native water is $210 \mathrm{mg} / \mathrm{L}$ over the entire model area. With selected dissolved-solids concentrations of 650 and $750 \mathrm{mg} / \mathrm{L}$ for the artificial-recharge water, the model can be used to simulate the movement of high-concentration plumes in the aquifer. Because the model is two-dimensional, it cannot simulate water-quality variations at depth within the aquifer; that is it is assumed that the recharge water mixes thoroughly with the aquifer water. Although information on the degree and depth of mixing is not presently available, the assumption that mixing occurs may be supported by (1) existence of a concentration gradient between the recharge water and aquifer water, (2) variation in permeability within the aquifer, and (3) alternation of periods of natural and artificial recharge.

Using the artificial-recharge rates at the nodes as indicated in table 9 and dissolved-solids concentrations of 650 and $750 \mathrm{mg} / \mathrm{L}$, simulations for the periods 1974-80, 1981-90, and 1991-2000 were made to calculate the areal extent of the plume of recharge water as it moves with time.

Figures 26-28 show the distribution of the dissolved-solids concentration for 1981, 1991, and 2000 as predicted by the model with artificial recharge at the 1974-2000 average annual rate and a concentration of $650 \mathrm{mg} / \mathrm{L}$.

If the effective boundary of the plume is defined as dissolved-solids concentration greater than 300 


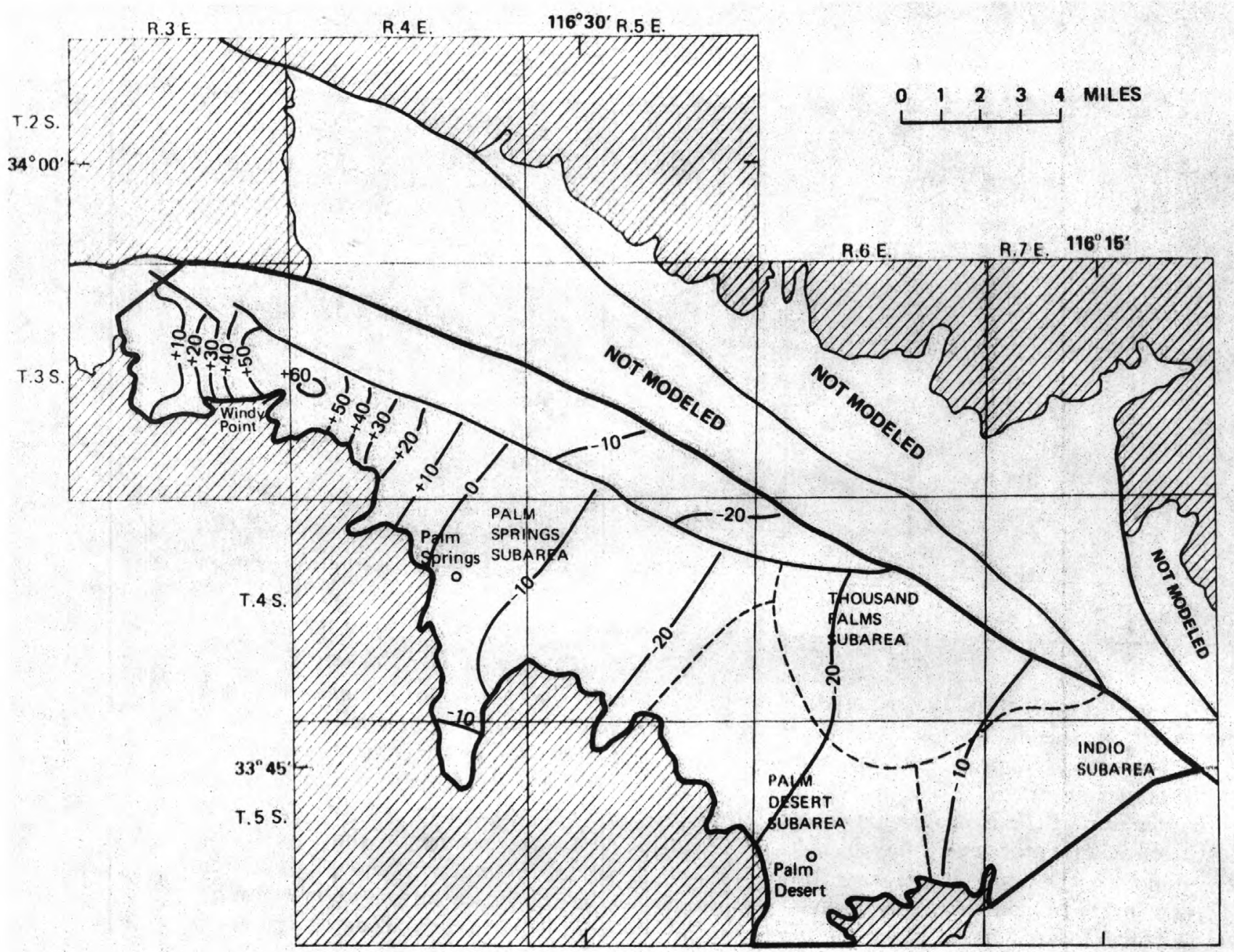

EXPLANATION

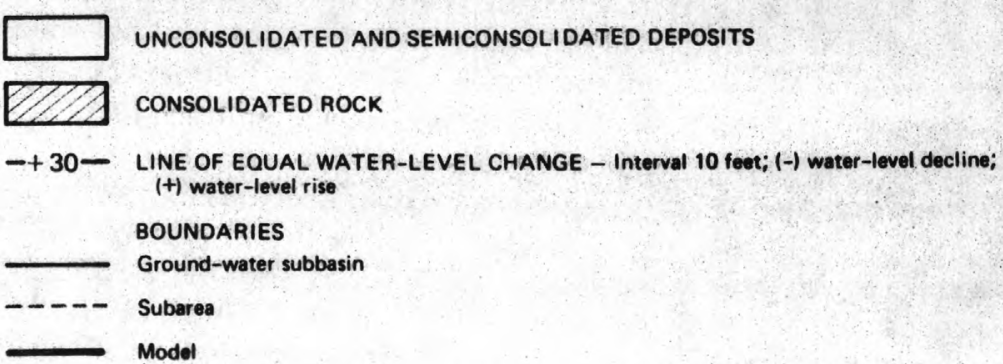

Figure 19.-Water-level change, 1974-80, with artificial recharge and projected pumage. 


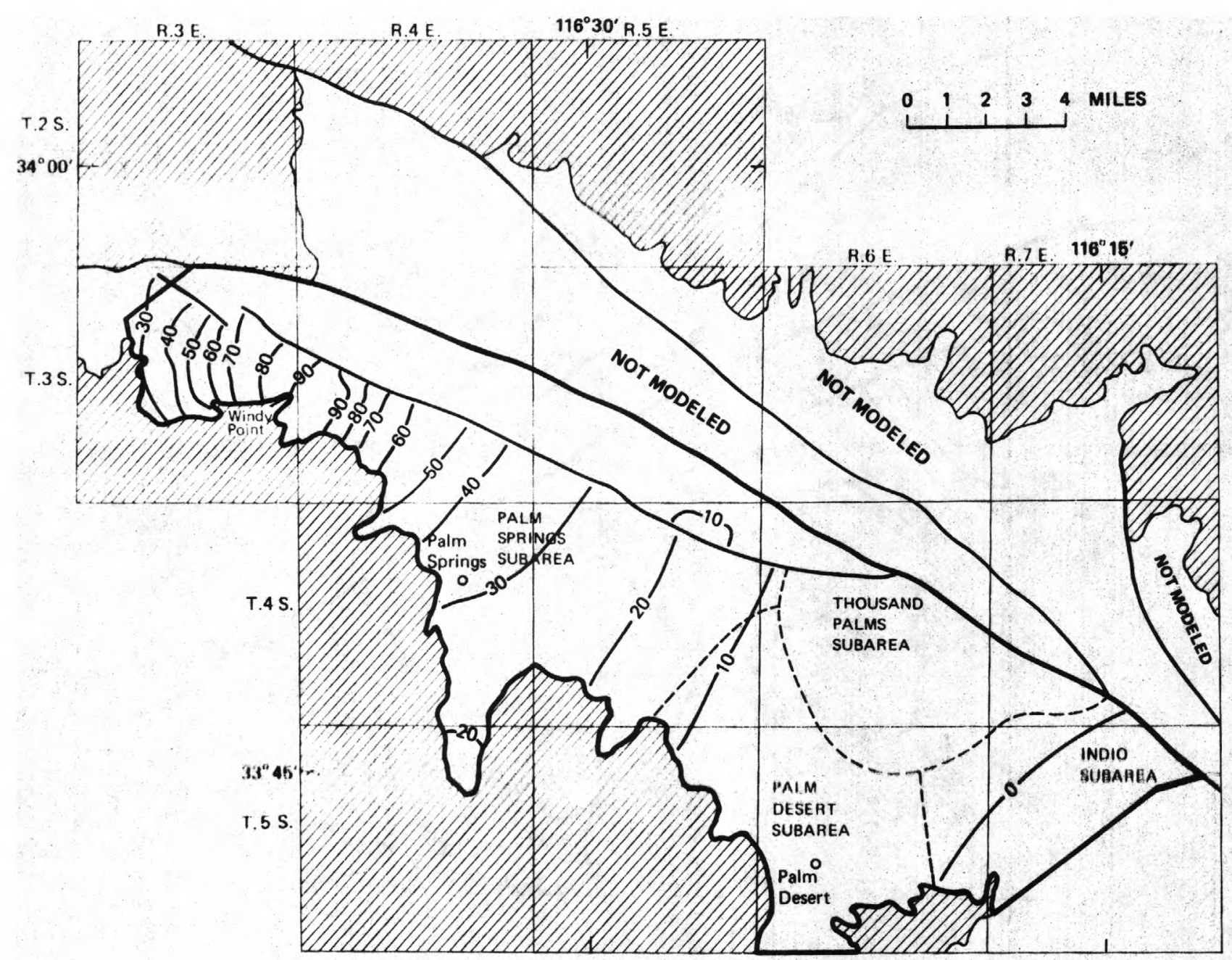

EXPLANATION

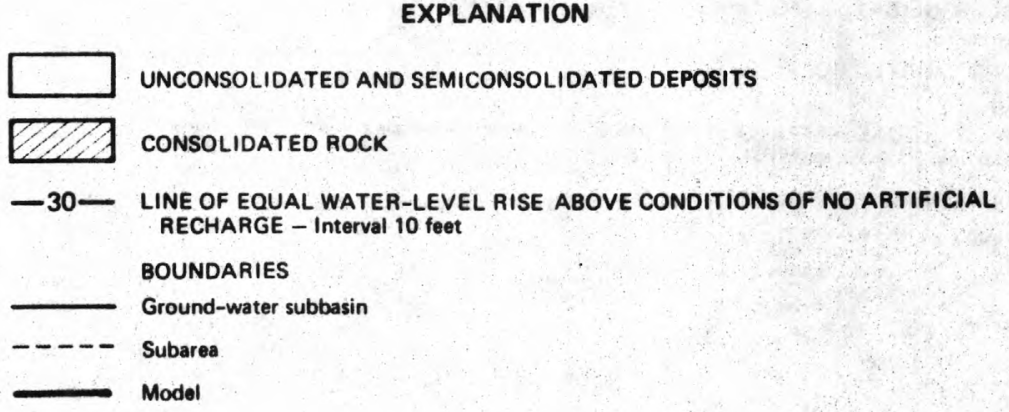

FIGURE 20.-Difference between projected water levels for 1981 under projected pumpage conditions and artificial recharge combined with projected pumpage condition. 


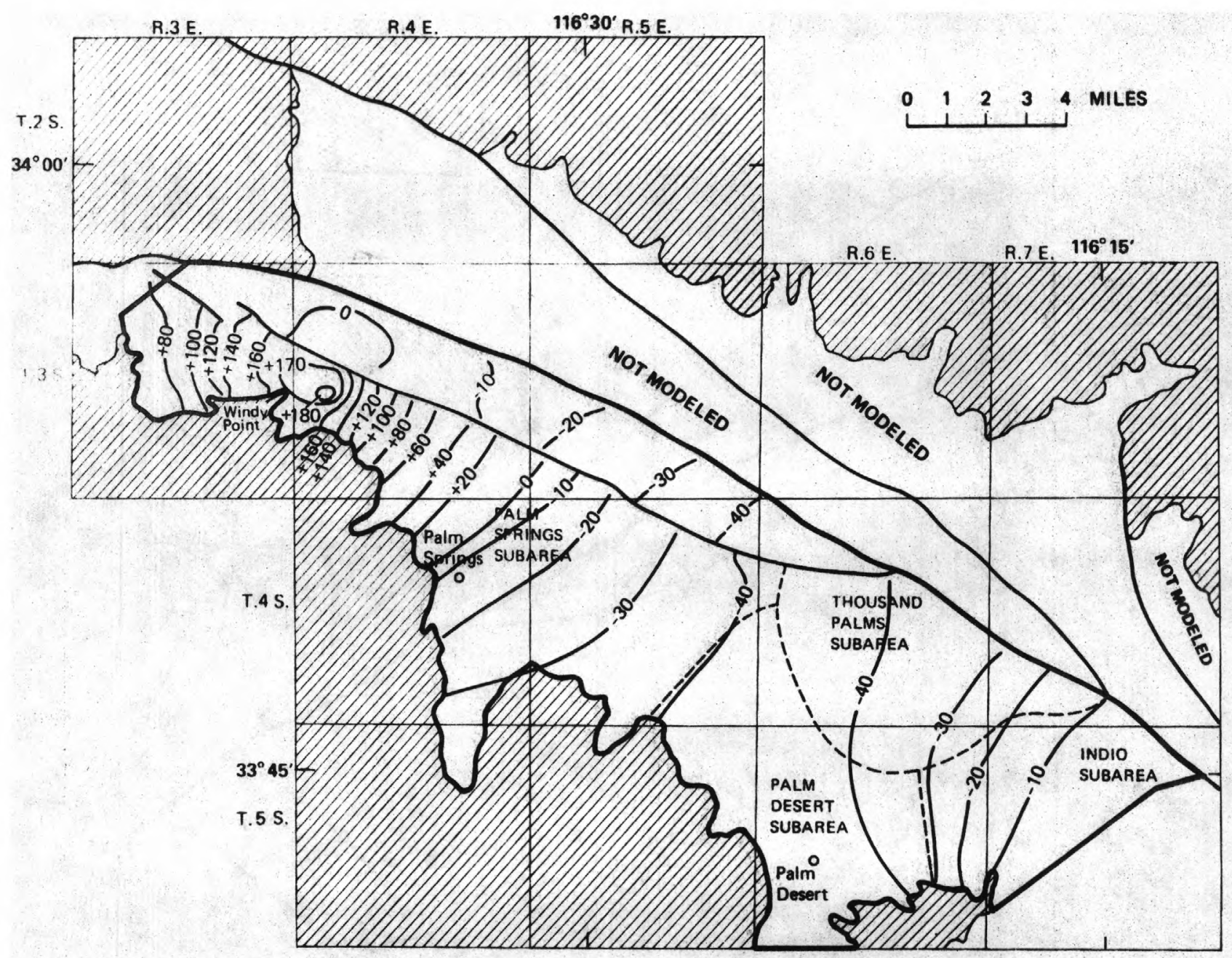

EXPLANATION

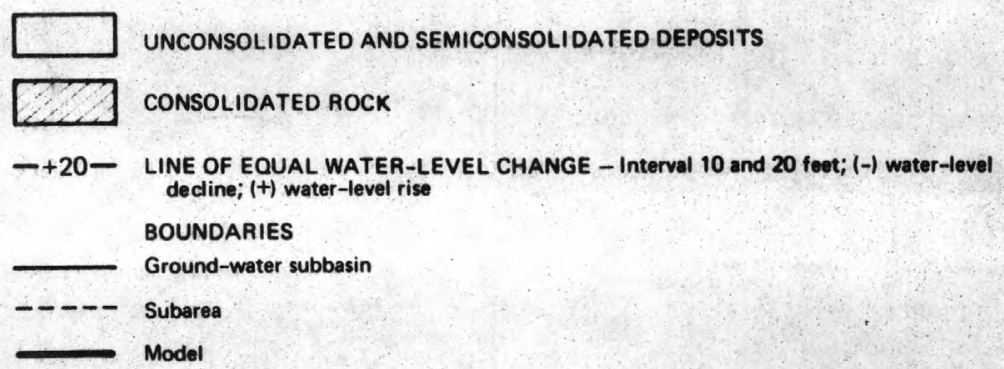

Figure 21.-Water-level change, 1974-90, with artificial recharge and projected pumpage. 


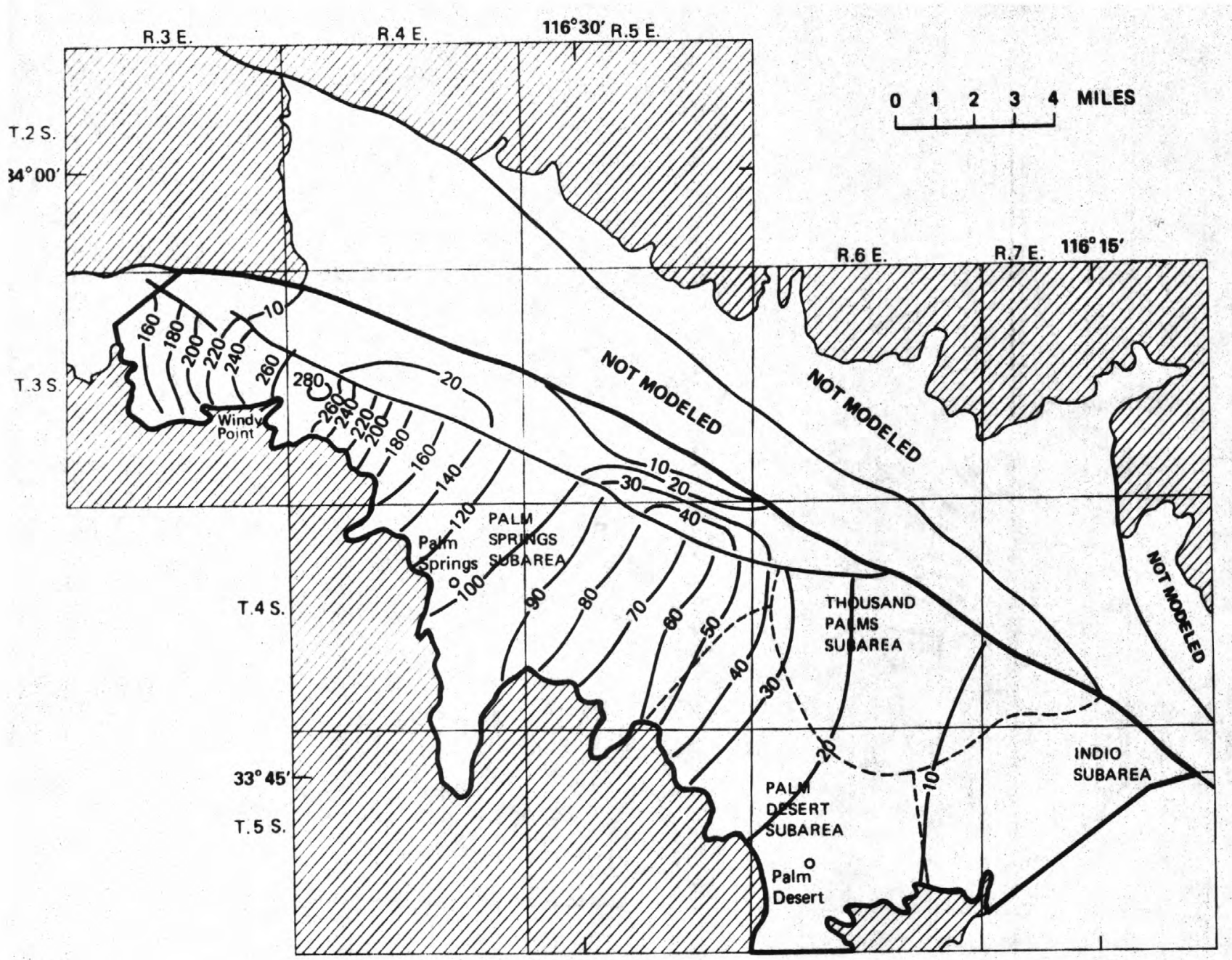

EXPLANATION

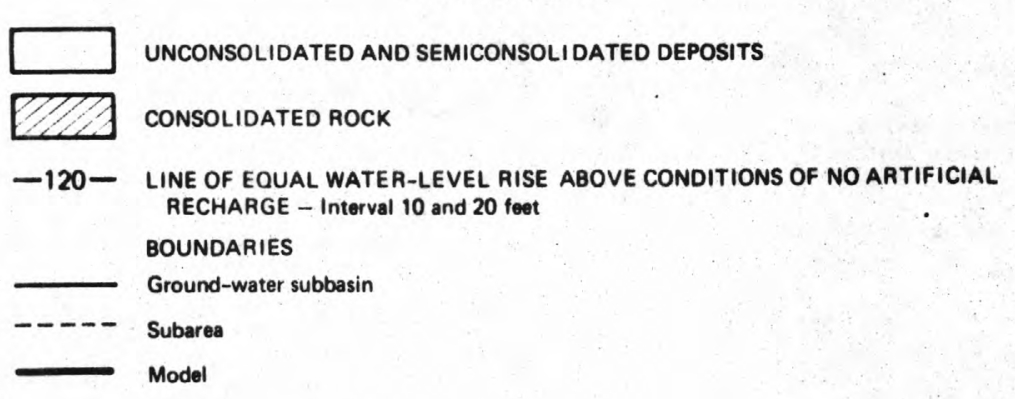

FIGURE 22.-Difference between projected water levels for 1991 under projected pumpage conditions and artificial recharge combined with projected pumpage condition. 


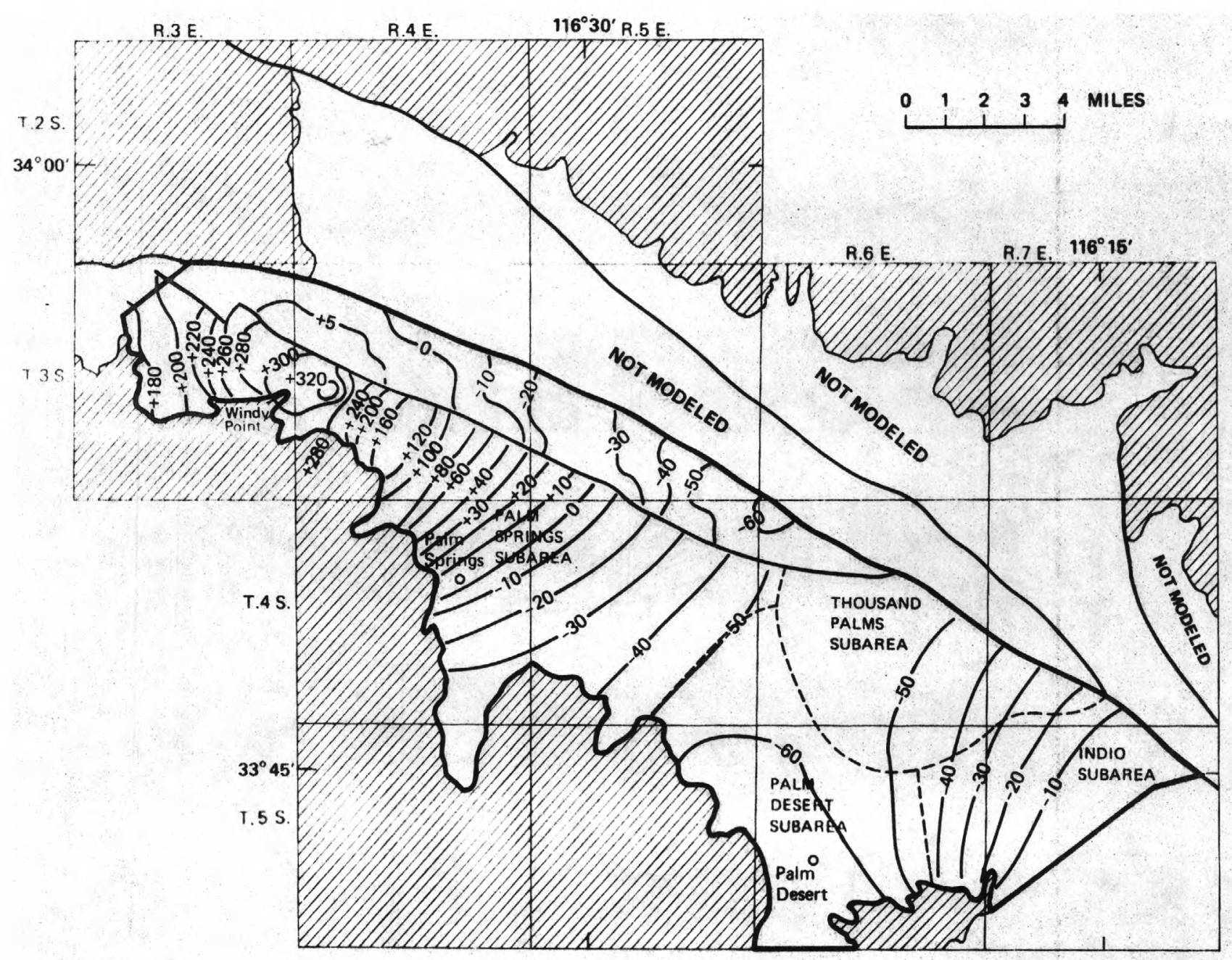

EXPLANATION

UNCONSOLIDATED AND SEMICONSOLIDATED DEPOSITS

CONSOLIDATED ROCK

-+160 - LINE OF EQUAL WATER-LEVEL CHANGE - Interval 5, 10, 20, and 40 foet; (-) water-level decline; $(+)$ water-level riso BOUNDARIES

- Ground-water subbasin

- - - Subarea

Model

FIGURE 23.-Water-level change, 1974-2000, with artificial recharge and projected pumpage. 


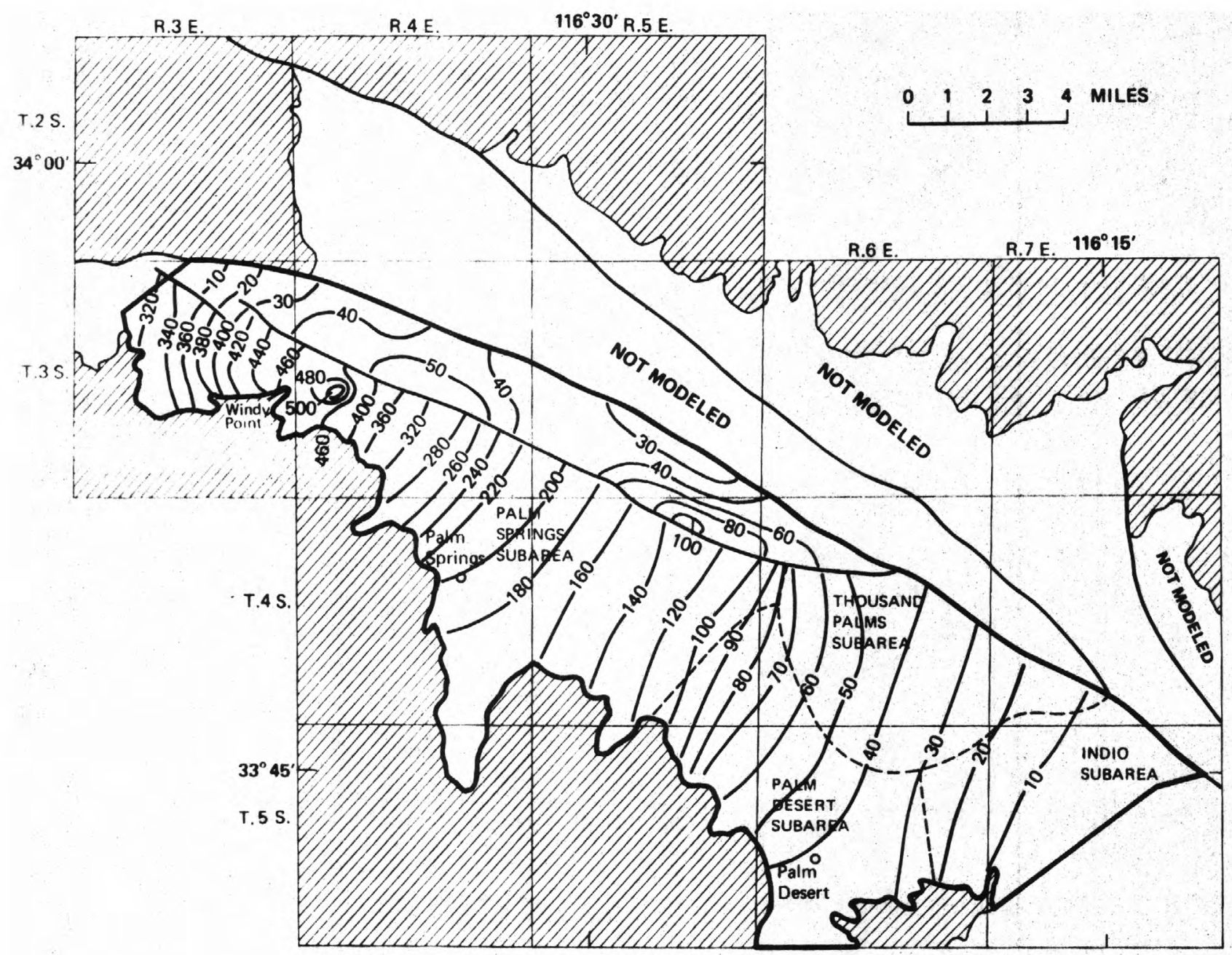

EXPLANATION

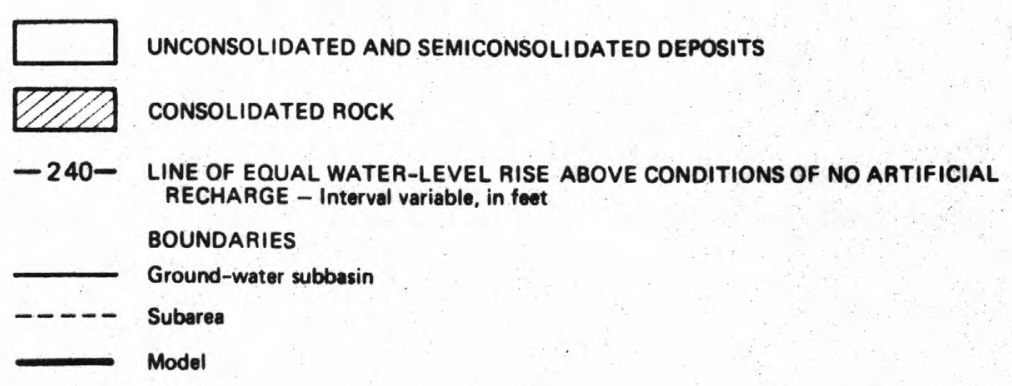

FigURE 24:-Difference between projected water levels for 2001 under projected pumpage conditions and artificial recharge combined with projected pumpage condition. 


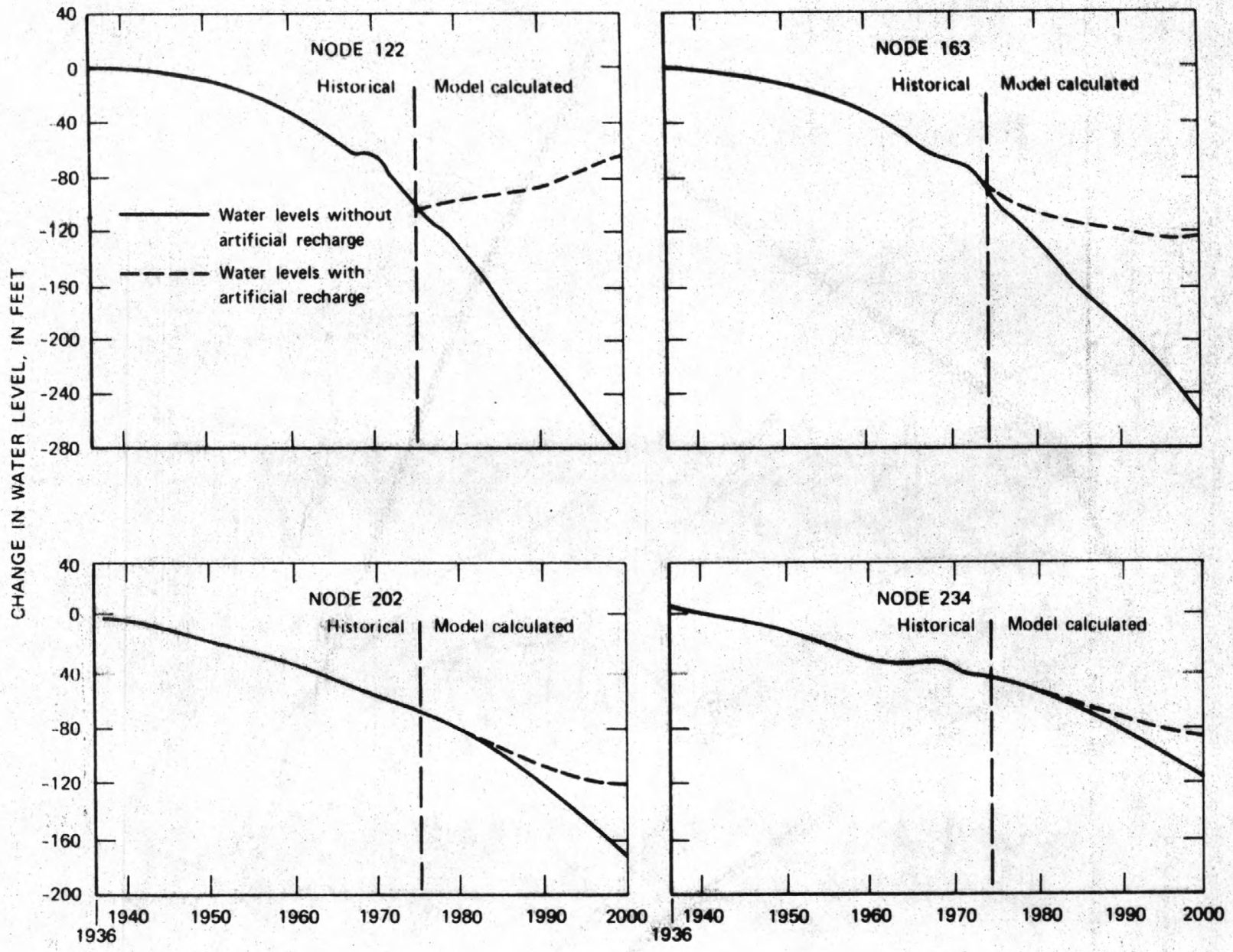

FiguRE 25.-Hydrographs for selected nodes showing water-level response to artificial recharge. Location of nodes shown in figure 9. 


\begin{tabular}{|c|c|c|c|}
\hline \multirow{2}{*}{$\begin{array}{l}\text { Node number } \\
\text { (fig. 14) }\end{array}$} & \multicolumn{3}{|c|}{$\begin{array}{l}\text { Rate of recharge } \\
\text { (acre-feet per year) }\end{array}$} \\
\hline & $1974-80$ & $1981-90$ & $1991-2000$ \\
\hline 14 & 1,000 & 2,000 & 2,000 \\
\hline 32 & 1,000 & 2,000 & 3,000 \\
\hline 59 & 1,000 & 3,000 & 4,000 \\
\hline 104 & 600 & 1,500 & 2,400 \\
\hline 105 & -- & 1,300 & 2,000 \\
\hline 112 & 800 & 2,000 & 3,000 \\
\hline 113 & 800 & 3,000 & 4,000 \\
\hline 114 & -- & 2,000 & 3,000 \\
\hline 115 & -- & -- & 2,000 \\
\hline 121 & 900 & 2,000 & 3,000 \\
\hline 122 & 1,000 & 3,000 & 4,000 \\
\hline 123 & 1,000 & 2,000 & 3,000 \\
\hline 124 & -- & -. & 2,000 \\
\hline 130 & 1,000 & 2,000 & 3,000 \\
\hline 131 & 1,100 & 3,000 & 4,000 \\
\hline 132 & 1,200 & 2,000 & 3,000 \\
\hline 133 & 1,300 & 1,000 & 2,000 \\
\hline 139 & -- & 2,000 & 3,000 \\
\hline 140 & 1,000 & 2,000 & 3,000 \\
\hline 141 & 1,100 & 2,000 & 3,000 \\
\hline 142 & 900 & 1,000 & 2,000 \\
\hline Total annual recharge & 16,700 & 38,800 & 60,400 \\
\hline
\end{tabular}

$\mathrm{mg} / \mathrm{L}$, it would extend $1.1 \mathrm{mi}$ downstream from the recharge pond and would have a maximum width of about $1 \mathrm{mi}$ by 1981 (fig. 26).

Figure 27 shows the movement of this recharge plume by 1991 as a result of the increased annual recharge rates for the 1981-90 simulation period. The effective boundary of the plume $(300 \mathrm{mg} / \mathrm{L})$ would extend to $3.1 \mathrm{mi}$ downstream from the recharge pond and would have a maximum width of $1.5 \mathrm{mi}$.

The third simulation (fig. 28) shows the dissolved-solids concentration that would exist by the year 2000 according to the model and as a result of the greater recharge rates for the 19912000 simulation period. This simulation shows that the effective boundary of the plume of recharge water would extend $4.5 \mathrm{mi}$ downstream from the end of the recharge pond and would be $2.2 \mathrm{mi}$ wide. By the year 2000 the $300-\mathrm{mg} / \mathrm{L}$ line would have moved downgradient past Indian Avenue and would approach Sunrise Way.

Concentration profiles along section $A-A^{\prime}$ (figs. 26-28) for the years 1981,1991 , and 2000, as predicted by the transport model for recharge water with a concentration of dissolved solids of 650 $\mathrm{mg} / \mathrm{L}$, are shown in figure 29. From these profiles the downgradient movement of the water-quality plume and the rate of movement can be determined by tracing the farthest downstream extent of a specific concentration value on successive 


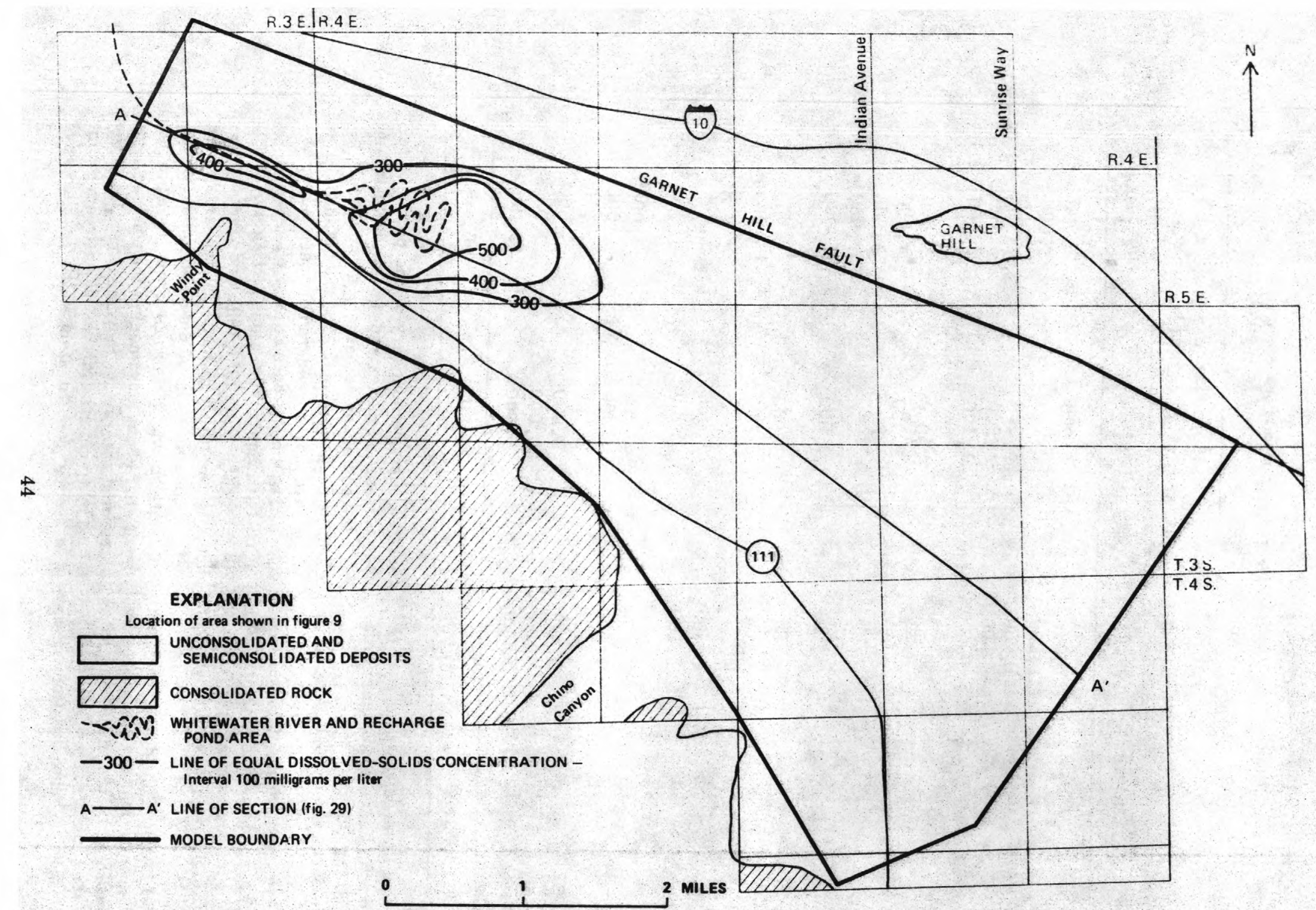

Figure 26.-Model-predicted dissolved-solids concentration for 1981, using 650 milligrams per liter artificial recharge water from Colorado River Aqueduct. 


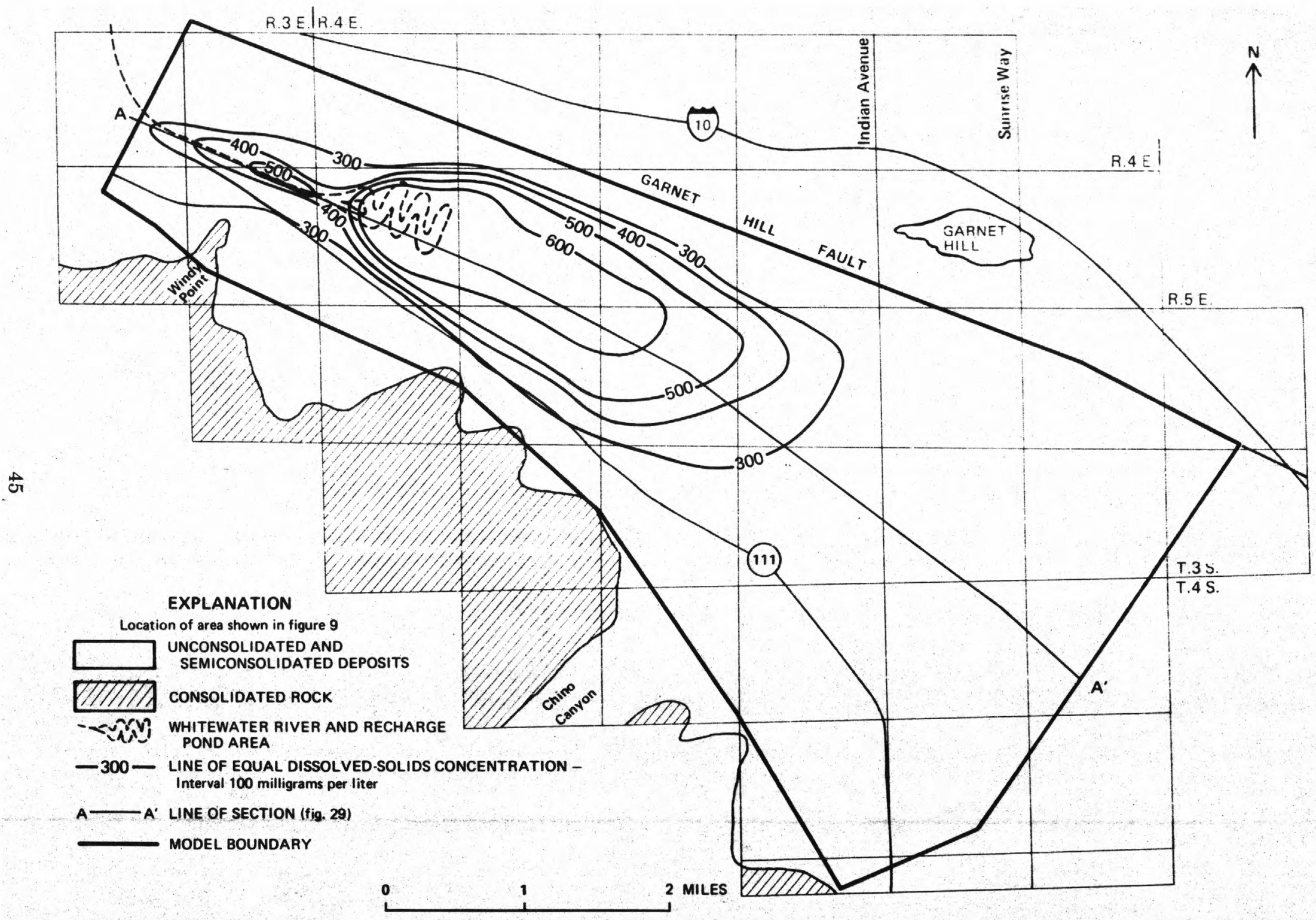

FIGURE 27.-Model-predicted dissolved-solids concentration for 1991, using 650 milligrams per liter artificial recharge water from Colorado River Aqueduct. 


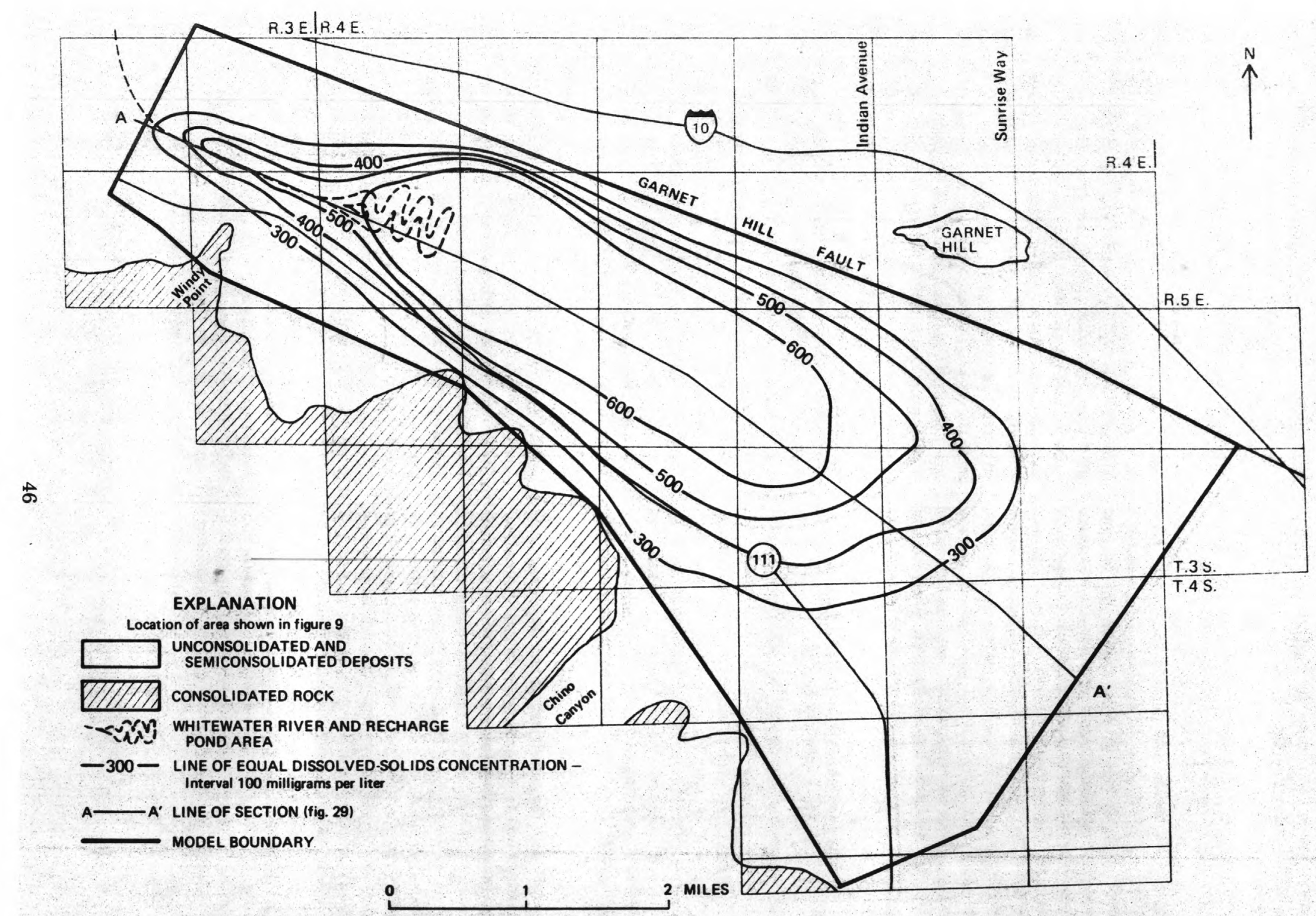

FIGURe 28. - Model-predicted dissolved-solids concentration for 2000, using 650 milligrams per liter artificial recharge water from Colorado River Aqueduct. 


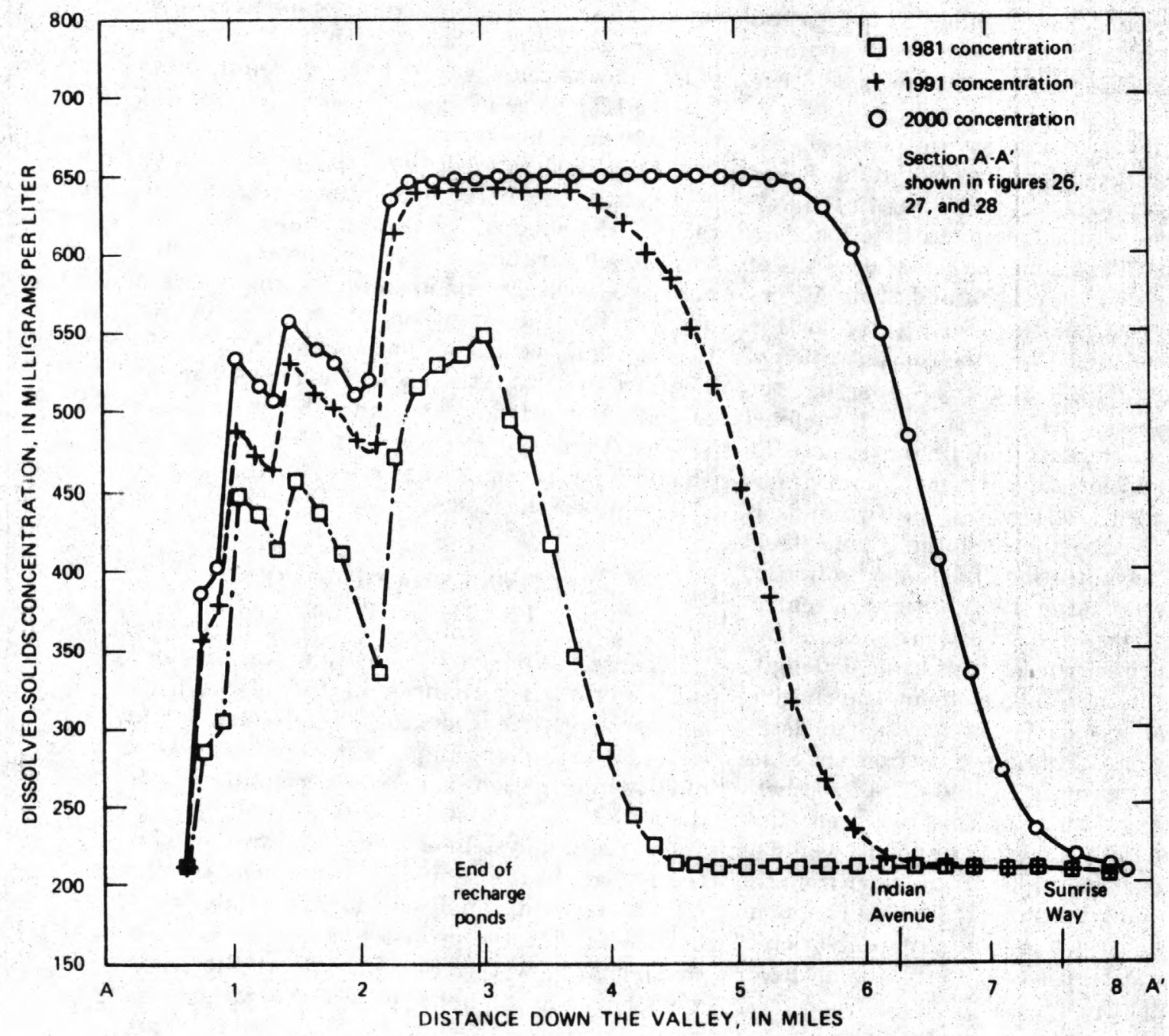

Figure 29. - C'oncentration profiles of dissolved solids along section A- $A^{\prime}$ of water-quality model for 1981, 1991, and 2000, using a dissolved-solids concentration of 650 milligrams per liter in the recharge water. 
profiles with time. The velocity of the recharged water in the recharge area would increase as the gradient is increased with time from an approximate rate of $300 \mathrm{ft}$ per year in 1974 to $1,000 \mathrm{ft}$ per year by 2000 .

In the computer runs made with the dissolvedsolids concentration for the Colorado River Aqueduct water increased to $750 \mathrm{mg} / \mathrm{L}$, the volume of recharge was identical to that listed in table 9. Figures 30,31 , and 32 show the results of these three runs for 1981, 1991, and 2000. A comparison of these simulations with those for the same time periods but using the concentration of (i5) $\mathrm{mg} / \mathrm{l}$, (figs. 26, 27, and 28) shows that the larthest downstream extent of the plume idefined by the $300-\mathrm{mg} / \mathrm{L}$ concentration line) is almost the same. In the run for 2000 the maximum difference in boundary locations for the two runs is about $650 \mathrm{ft}$. Within the recharge plume itself, however, the concentration of dissolved solids for the runs using recharge water with a concentration of $750 \mathrm{mg} / \mathrm{L}$ is increased proportionally above the value resulting from the runs using $650 \mathrm{mg} / \mathrm{L}$.

In testing another management alternative, the water-quality model was stressed to determine the effect of recharging water from the State Water Project beginning in 1991. The hypothetical conditions assumed for this test were that water from the Colorado River Aqueduct would be used for recharge until 1991 when water from the other source would become available. The same volume of recharge (table 9 ) at a concentration of $750 \mathrm{mg} / \mathrm{L}$, would be used for the Colorado River Aqueduct water from 1974 to 1990 . Thus, from 1974 to 1990 the water-quality conditions would be as predicted in previous simulations for 1991 (fig. 31). From 1991 to 2000 the recharge volume was also as listed in table 9, but the dissolvedsolids concentration for State Water Project water was assumed to be $250 \mathrm{mg} / \mathrm{L}$.

The results of the 1991-2000 run with recharge water from the State Water Project are shown in figure 33 . Note that in this run also, the downgradient extent of the plume delineated by the $300-\mathrm{mg} / \mathrm{L}$ concentration line is almost identical to the extent of the runs using concentration values of 650 or $750 \mathrm{mg} / \mathrm{L}$ for the recharge water throughout the simulation period. The upstream end of the plume in the area of the recharge ponds, however, would have atrophied. In addition, the maximum concentration in the recharge plume downstream would have decreased from $700 \mathrm{mg} / \mathrm{L}$ or more in figure 32 to something less than $700 \mathrm{mg} / \mathrm{L}$ in figure 33 .

As previously stated, the water-quality model is presently uncalibrated, and the degree of accuracy of the predictions is not known. Because these results are dependent upon the values of the parameters chosen and upon the assumption that average natural conditions prevail, the predictions are subject to revision if any of these conditions are in substantial error. The model was relatively unaffected by varying the dispersivity values; therefore, changes in this parameter should have no significant effect on the simulation results of the model.

\section{RECOMMENDATIONS FOR FURTHER STUDY}

Because there have been no significant historical water-quality changes in the model area, against which the model could be checked, it will continue to be very important to collect waterquality information in order to check and update the model.

The present system of monitoring five wells in the recharge area should be continued; samples for water-quality analysis should be collected to help determine the precise rate of movement of the recharge water. In addition, as the above wells only tap the upper part of the aquifer, the installation of two deep test wells containing multiple casings sealed off from each other would aid in determining the depth and degree of mixing of the recharge water and aquifer water. Lithologic and geophysical logs as well as water-level and water-quality data from these test wells will also aid in the calibration of the model and improve the accuracy of the predictions as the various aquifer parameters are better defined.

The models may also be utilized in other simulations by the water agencies to test other water-management alternatives prior to actually imposing the practices upon the ground-water basin itself. 


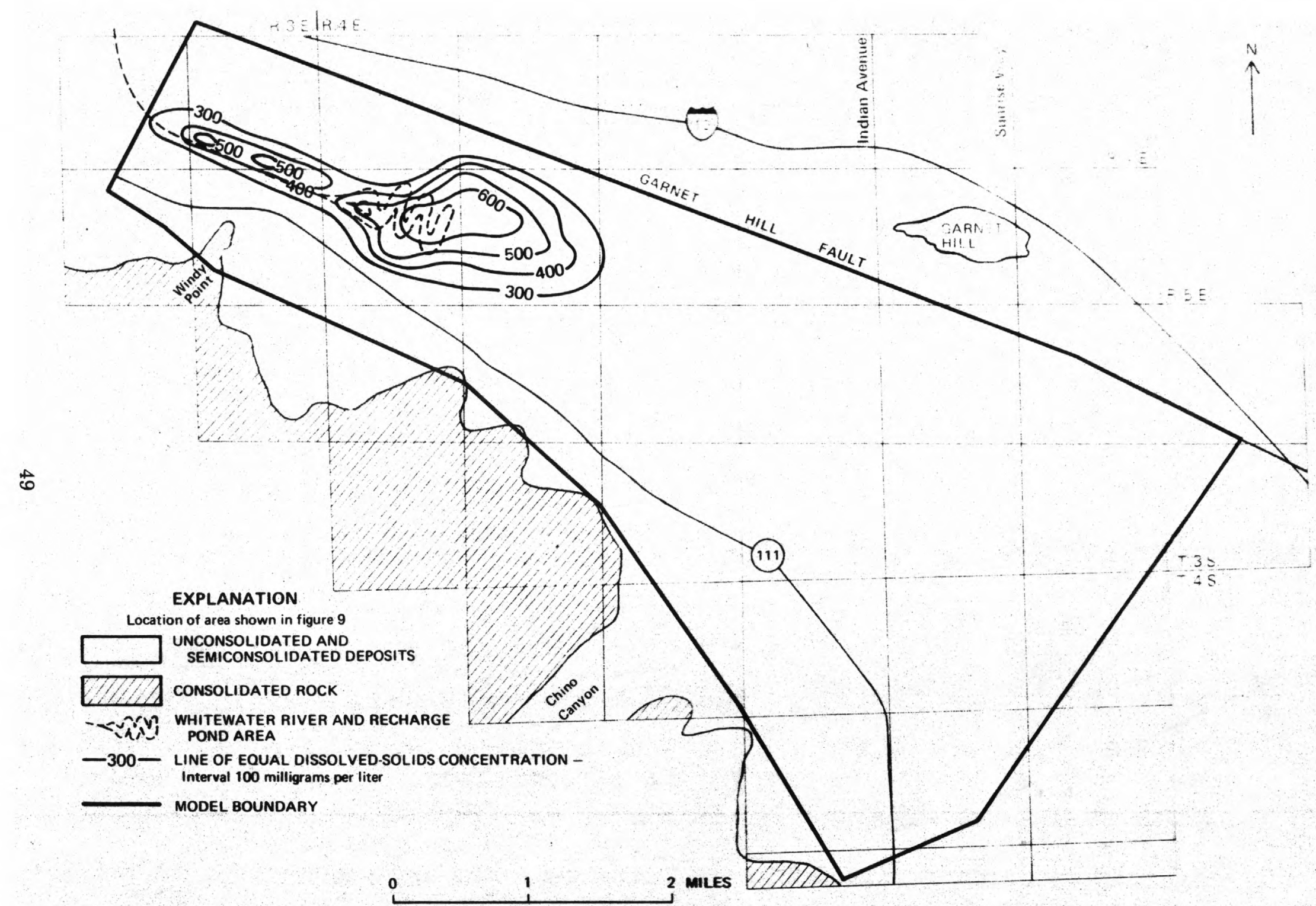

Figure 30.-Model-predicted dissolved-solids concentration for 1981, using 750 milligrams per liter artificial recharge water from Colorado River Aqueduct. 


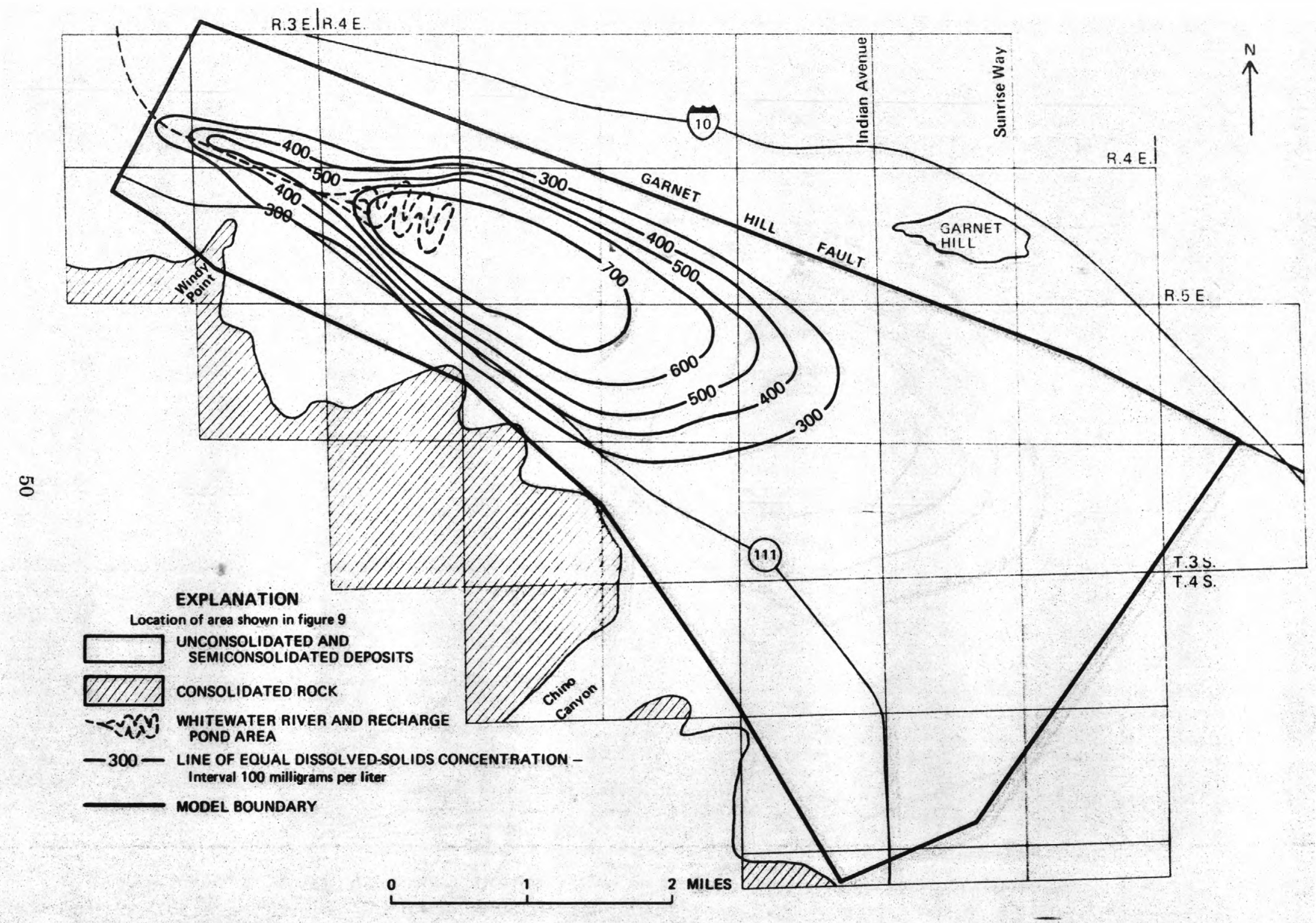

Figurg 31.-Model-predicted dissolved-solids concentration for 1991, using 750 milligrams per liter artificial recharge water from Colorado River Aqueduct. 


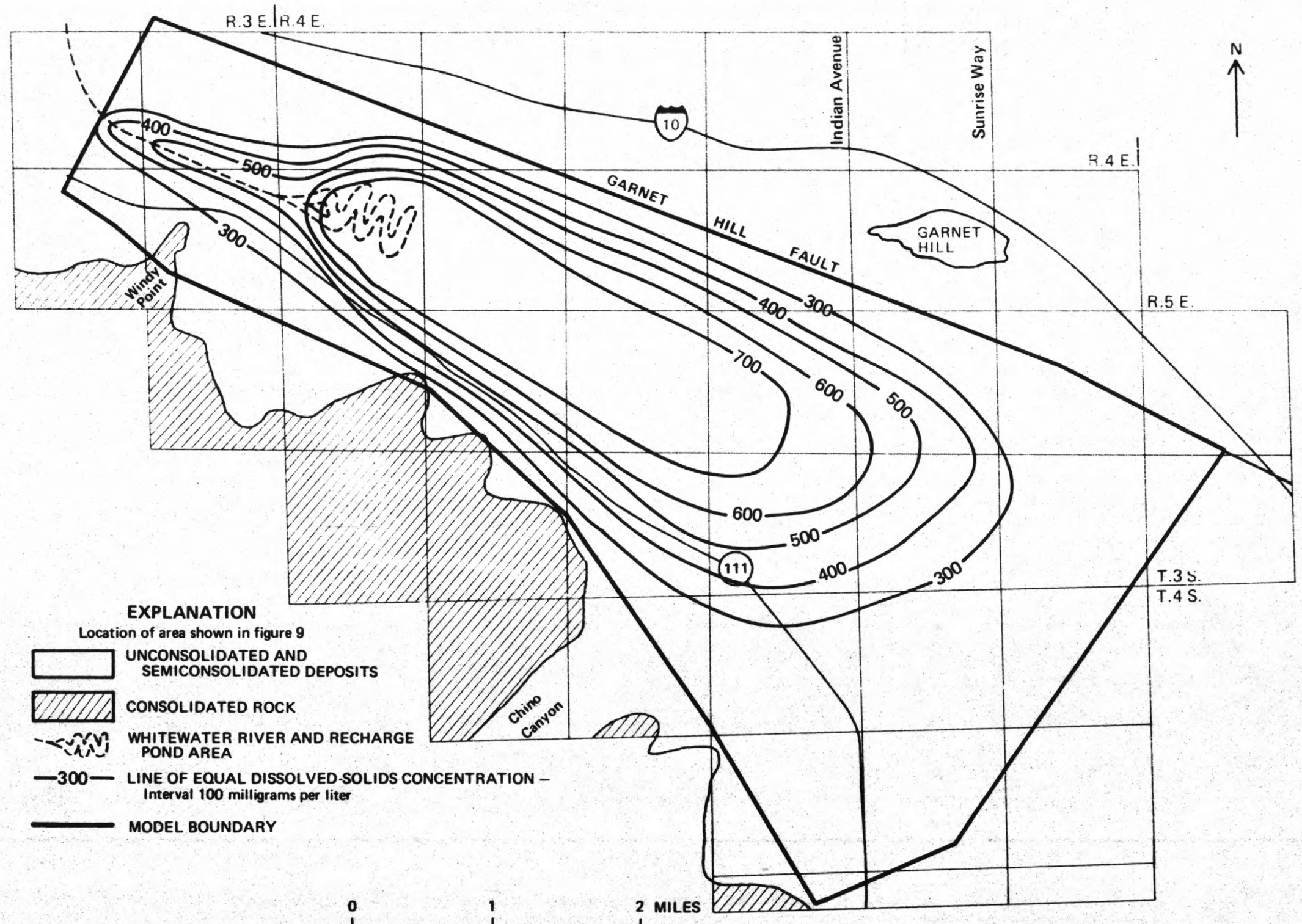

FIGURE 32.-Model-predicted dissolved-solids concentration for 2000 , using 750 milligrams per liter artificial recharge water from Colorado River Aqueduct. 


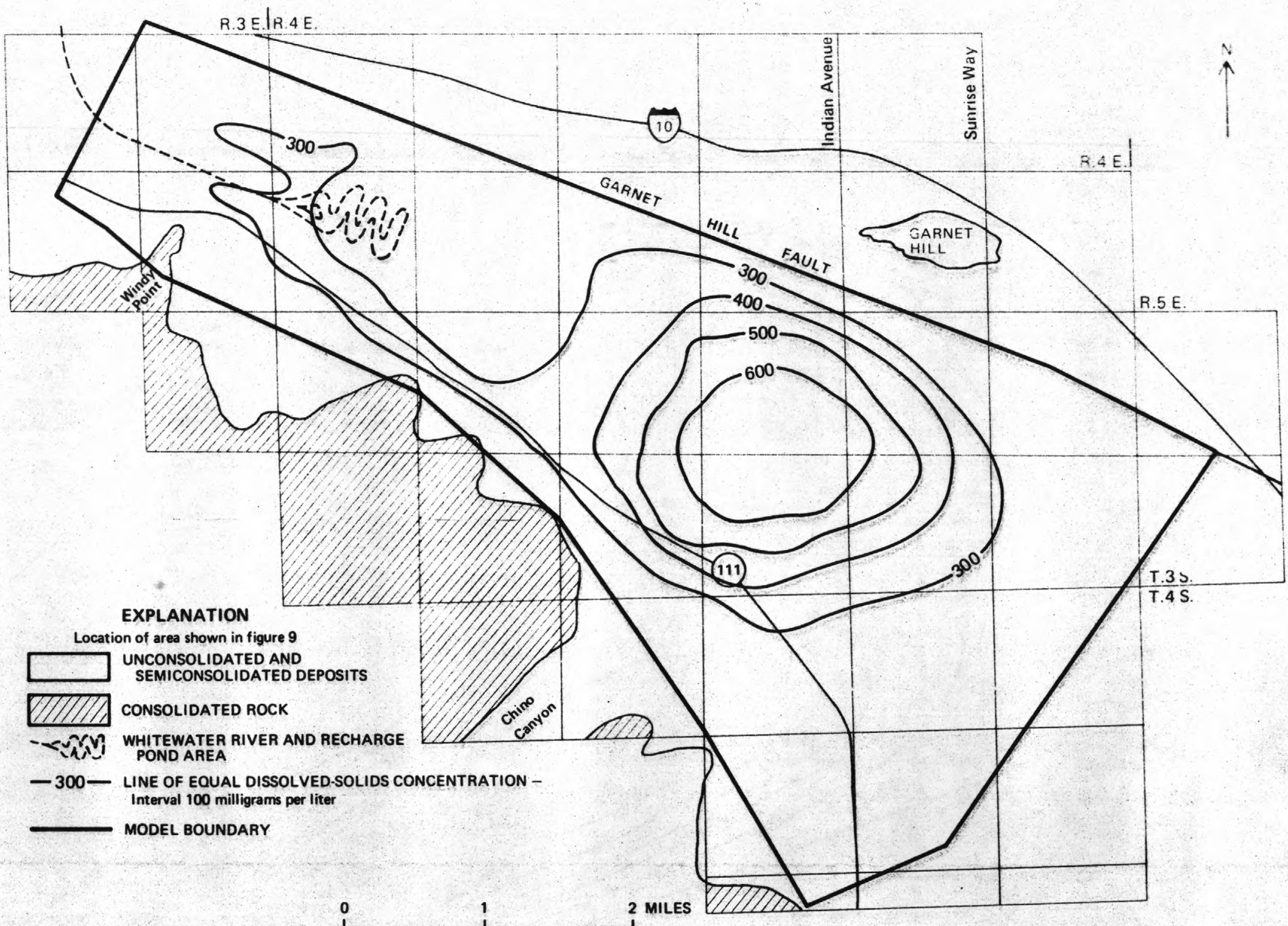

FIGURE 33.-Model-predicted dissolved-solids concentration for the year 2000, using Colorado River Aqueduct water as artificial recharge from 1974 to 1991 (750 milligrams per liter) and State Water Project water from 1991 to 2000 (250 milligrams per liter). 


\section{SUMMARY}

Basic ground-water quality data were collected for the upper Coachella Valley, and flow and water-quality digital models were constructed for the Garnet Hill and Whitewater River subbasins to answer the following questions:

1. What are the past and present water-quality conditions of the ground-water basin?

2 . What effect will artificial recharge have on future water levels in the basin?

3 . What effect will artificial recharge have on future water quality in the basin?

Water-level data revealed that from 1936 through 1973 water levels in the basin declined more than $100 \mathrm{ft}$ in part of the Palm Springs subarea and more than $70 \mathrm{ft}$ in part of the Palm Desert subarea.

The three subbasins north of Garnet Hill fault contain principally sodium sulfate type water, whereas water in the Whitewater River subbasin is predominantly a calcium bicarbonate type. The recharge water from the Colorado River Aqueduct fluctuates from a sodium sulfate to a calcium sulfate type.

Mapping of chloride, sulfate, and dissolved solids revealed that the greatest concentrations occur in the northernmost subbasins and decreases southward. Dissolved-solids concentrations have a maximum value of more than $1,000 \mathrm{mg} / \mathrm{L}$ in the Desert Hot Springs subbasin and a minimum of less that $200 \mathrm{mg} / \mathrm{L}$ in some areas of the Whitewater River subbasin. The dissolved-solids concentration in the recharge water ranges from 600 to $750 \mathrm{mg} / \mathrm{L}$. Despite the areal differences in dissolved-solids concentration in the valley, changes with time have been minor for each of the subbasins from the earliest samples collected in the 1930's.

The model chosen for flow simulation used the finite-element numerical solution with isoparametric quadrilateral elements. Calibration of the flow model resulted in transmissivity distributions of $20 \mathrm{ft}^{2} / \mathrm{d}$ to $70,000 \mathrm{ft}^{2} / \mathrm{d}$ over the basin and storage coefficients from 0.02 to 0.19 .

Flow-model predictions were made for three time periods: 1974-80, 1981-90, and 1991-2000. For each time period water levels were calculated from (1) projected pumpage only and (2) projected recharge and pumpage. Results of the 1974-80 simulation showed that where maximum waterlevel declines of $40 \mathrm{ft}$ occur in the vicinity of Palm Springs without recharge there would be only 10 $\mathrm{ft}$ of decline with recharge. Near Palm Desert the decline would be $20 \mathrm{ft}$ without recharge and $17 \mathrm{ft}$ with recharge. Results of the 1974-90 simulation showed that where a maximum decline of $120 \mathrm{ft}$ would occur in the vicinity of Palm Springs without recharge, only $20 \mathrm{ft}$ would occur with recharge. At Palm Desert the decline would be nearly $60 \mathrm{ft}$ without recharge and about $40 \mathrm{ft}$ with recharge.

Finally, the simulation from 1974 through 2000 showed a maximum water-level decline of about $200 \mathrm{ft}$ in the vicinity of Palm Springs without recharge. With artificial recharge the water level at the same location would rise to about the 1974 level. Near the Palm Desert the decline would be about $100 \mathrm{ft}$ without recharge and $60 \mathrm{ft}$ with recharge. These declines would (1) cause some wells to go dry, (2) decrease well yields, and (3) increase pumping costs as the lift is increased up to 200 additional feet.

The water-quality model, which is also based on the finite-element numerical solution, covers only $20 \mathrm{mi}^{2}$ in the northwestern part of the flow-model area. Assuming a uniform initial dissolved-solids concentration of $210 \mathrm{mg} / \mathrm{L}$ over the area, longitudinal and transverse dispersivities of $100 \mathrm{ft}$ and 33 $\mathrm{ft}$, respectively, and a porosity of 0.25 , the presently uncalibrated model was used to predict movement of recharge water having dissolvedsolids concentrations of 650 and $750 \mathrm{mg} / \mathrm{L}$. Using the $300-\mathrm{mg} / \mathrm{L}$ concentration line as a boundary, the movement of the recharge plume was traced for three time periods: $1974-80,1981-90,1991-$ 2000. The results show that the plume would have moved $1.1 \mathrm{mi}$ down the valley from the recharge pond by $1981,3.1 \mathrm{mi}$ by 1991 , and $4.5 \mathrm{mi}$ by 2000.

Water-quality model simulations using dissolved-solids concentrations of 650 and 750 $\mathrm{mg} / \mathrm{L}$ for the recharge water resulted in plume sizes that were similar and locations that were within $650 \mathrm{ft}$ of each other. A simulation to determine the effects of recharging with water from the State Water Project from 1991 to 2000 showed that the plume would be atrophied at the upstream end and would decrease in concentration at the downstream end. 


\section{REFERENCES CITED}

Biehler, Shawn, 1964, Geophysical study of the Salton trough of southern California: California Inst. Technology, Ph.D. thesis, $139 \mathrm{p}$.

Bloyd, R. M., Jr., 1971, Underground storage of imported water in the San Gorgonio Pass area, southern California: U.S. Geol. Survey Water-Supply Paper 1999-D, 37 p.

Bredehoeft, J. D., and Pinder, G. F., 1973, Mass transport in Howing ground water: Water Resources Research, v, 9, no. 1, p. $194-210$

Jenne, E. A., and Truesdell, A. H., 1973, Identification of recharge sources and an evaluation of possible waterquality effects of artificial recharge as indicated by mineral equilibria calculations, in Tyley, S. J., Artificial recharge in the Whitewater River area, Palm Springs, California: U.S. Geol. Survey open-file report, p. 29-43.

Konikow, L. F., and Bredehoeft, J. D., 1974, Modeling flow and chemical quality changes in an irrigated stream-aquifer system: Water Resources Research, v. 10 , no. 3 , p. 546562.
Pinder, G. F., 1973, A Galerkin finite element simulation of ground water contamination on Long Island, New York: Water Resources Research, v. 9, no. 6, p. 1657-1669.

Pinder, G. F., and Page, R. H., 1977, Finite element simulation of salt water intrusion on the South Fork of Long Island: Internat. Conf. on Finite Elements in Water Resources, 1st, Princeton Univ., 1976, p. 2.51-2.69.

Robson, S. G., 1974, Feasibility of digital water-quality modeling illustrated by application at Barstow, California: Menlo Park, Calif., U.S. Geol. Survey Water-Resources Inv. $46-73,66 \mathrm{p}$.

Scheidegger, A. E., 1961, General theory of dispersion in porous media: Jour. Geophys. Research, v. 66 , no. 10, p. 3273-3278.

Tyley, S. J., 1973, Artificial recharge in the Whitewater River area, Palm Springs, California: U.S. Geol. Survey openfile report, $51 \mathrm{p}$.

1974, Analog model study of the ground-water basin of the upper Coachella Valley, California: U.S. Geol. Survey Water-Supply Paper 2027, 77 p. 


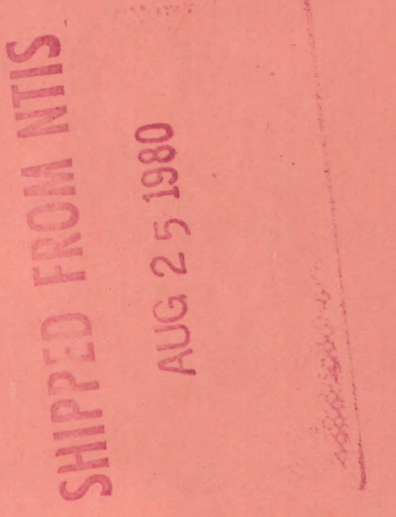

